\title{
ENERGY SECURITY IN NEW \\ ZEALAND POLITICS: RISK \\ PERCEPTIONS AND \\ POLITICAL AGENDAS
}

\section{By Lucy Sarah Moor Tyndall}

A Thesis Submitted to the Victoria University of Wellington in Partial Fulfilment of the Requirements for the Degree of Master of Arts in Political Science

School of History, Philosophy, Political Science and International Relations

Victoria University of Wellington 


\section{Abstract}

Energy security is a subjective concept, as to different actors it invokes different meanings and thoughts about risk. It is highly political because it is at the heart of the debate between the environmental consequences of burning fossil fuels and the economic consequences of constraining this consumption. How a government perceives energy security provides an important indication of how they intend to approach the complexity of current energy issues. No more important is energy security to consider than in New Zealand. As this thesis will show, the term is used in New Zealand's policy-making circles but it is not referred to consistently. This thesis will use the Copenhagen School's Theory of Securitisation and delineate the key features of energy security in New Zealand politics. It will show that there has been two distinct rhetorical politicisations of energy security that argue for two divergent energy policies. First, the Clark Labour Government used a strategy of politicisation to bring energy security risks onto the political agenda. This sought to legitimise strong government leadership in the energy sector to support the development of robust climate change policy. The second rhetorical politicisation is at the heart of the Key National Government, where energy security is subsumed to the immediate concern for economic growth in the wake of the global economic recession. Thus there is a heightened concern for short-term risk to security of energy supply and New Zealand's role in contributing to global energy security. The nature of energy security issues and how they are integrated with other policy challenges remain in dispute. Consequently, energy security is a highly contested and politicised concept in New Zealand politics. 


\section{Acknowledgements}

First and foremost I would like to thank my family for their unyielding support throughout my university years. As always, love to you all.

To my friends and colleagues who gave up their time to read my thesis, listen to my rants, and more than once offer a consolatory whisky in times of stress. Hannah Morgan in particular, you are one of the few with strong constitution to read until the end and make it out alive, and gave extraordinary editing advice and comments right the way through. Yours is a friendship that money certainly cannot buy, and I am forever in your debt. Thanks also to David Kempthorne and Matthew Castle for their comments and thoughts, as well as Andrew Bishop for the coffees, Corin Higgs for the 10 year old Laphroaig whisky, and Castle for purchasing the 18 year old Laphroaig from Duty Free. Best wishes for your own academic pursuits.

Thank you to my supervisors David Capie and Ben Thirkell-White for the guidance and dialogue to set me on the right path. Thanks also to the Victoria University administration staff, particularly Naomi West and Adrienne Nolan. To the people who took time to be interviewed for this thesis, thank you also. Your help was much appreciated. Particularly Barry Barton, Ralph Sims, Richard Hawke, David Parker and Stuart Calman.

And to my previous lecturers in the Political Science and French Departments of Otago University, the value and quality of education and support I received has undoubtedly got me to where I am today. Not easily forgotten. 


\section{Table of Contents}

Chapter 1 - Introduction ........................................................................................6

Energy security in international politics ............................................................ 8

Energy security in New Zealand politics................................................................13

The Copenhagen School Theory of Securitisation..................................................19

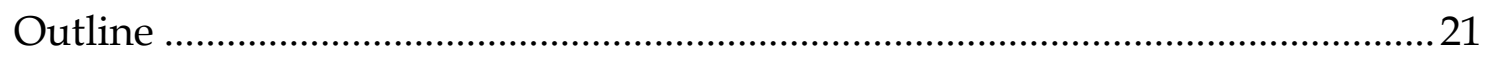

Chapter 2 - Energy Security and the Copenhagen School Theory of

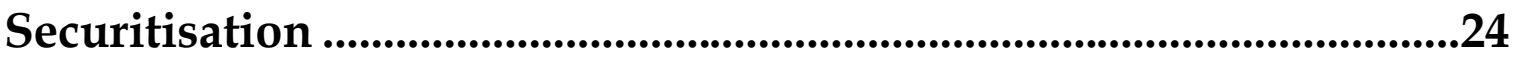

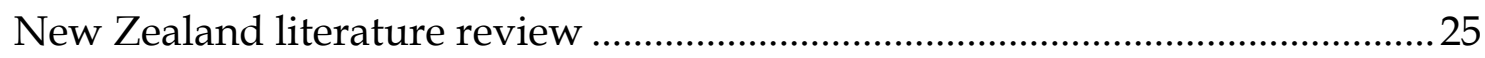

Risk perceptions and energy security theory ………………………………….....2 27

Securitising moves: who, what and where? …………………………................. 31

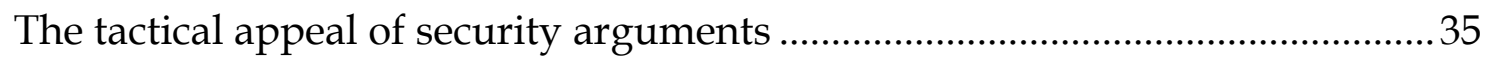

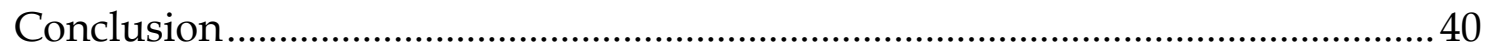

Chapter 3 - The Clark Labour Government, Energy Security and

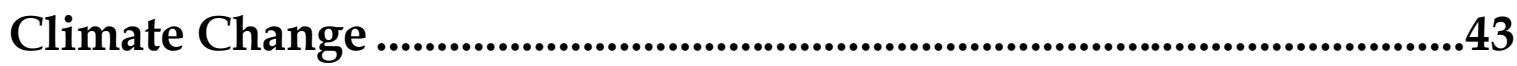

The New Zealand Energy Strategy to 2050: powering our future..........................4 44

Risk perceptions and climate change policy …………………………………...... 45

The politicisation of energy security................................................................. 50

Energy security and the New Zealand international climate change agenda 53

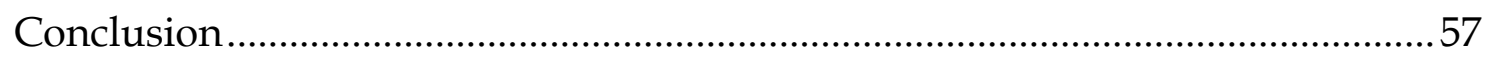

Chapter 4 - The Key National Government, Energy Security and Economic Growth................................................................................58

The New Zealand Energy Strategy 2011 - 2021: developing our energy potential .59

Risk perceptions and economic growth................................................................61

Energy security: security of supply ……………………………………….......62

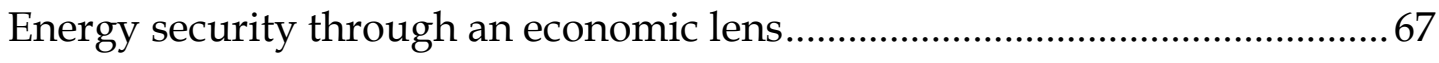

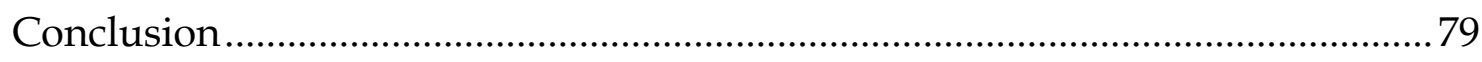

Chapter 5 - Energy Security and Political Agendas...............................81

The development of energy policy under the Clark Labour Government..........81 
The development of energy policy under the Key National Government ......... 91

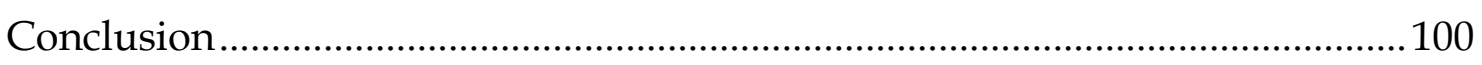

Chapter 6 - Conclusion...........................................................................102

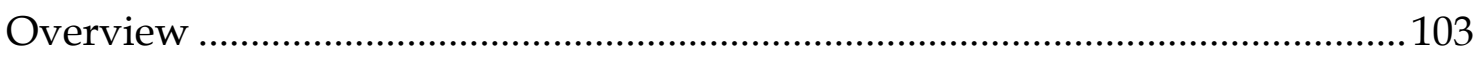

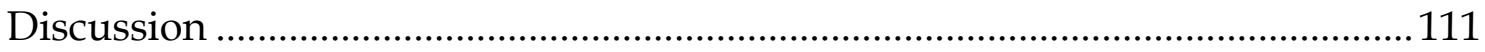

Bibliography 


\section{Chapter One}

\section{Introduction}

Energy security is the cornerstone of a well-functioning economy and a nation's standard of living. The challenges of climate change and increasing global demand for energy have deepened international debate on what energy security means today, and how it can be achieved in domestic policy in both environmental and economic terms. This thesis examines how energy security is understood in New Zealand politics and the role it has had in energy policyformation. It asks whether energy security has been politicised in New Zealand politics and if so, how has it been politicised? And finally, has politicisation of energy security helped or hindered energy policy formation? To answer these questions I argue that it is necessary to analyse how government presents risks to the energy system, and how those risks are responded to in policy-making. This thesis will therefore provide a detailed analysis of the political debate concerning New Zealand's policy response to the challenges of climate change and economic growth, at the heart of which is energy security. I aim to contribute wider understanding of what shapes and informs energy policy in New Zealand, how politicisation of energy security has affected this process, and give insight into the nature of the country's energy politics.

The politics of energy security in New Zealand has not been analysed in academic literature. I seek to fill this gap and in doing so, demonstrate that energy security has been politicised in policy-formation. I argue that while politicisation has raised the profile of energy security in energy policy, discourse on energy security remains contestable and inchoate. The thesis will demonstrate this by highlighting two competing perceptions of risks that are shaped by two distinct political agendas. The first political agenda is epitomised by the Clark Labour Government: a strategy of politicisation was used to bring long-term risks 
to energy security to the forefront of energy policy. Its energy security rhetoric aimed to legitimise robust climate change policy. The opposing political agenda is influenced by the Key National Government's goal of economic growth and key stakeholders in the energy market who favour a business-as-usual approach in energy policy. The Key Government has kept energy security as a policy focus, but conceptualises risk differently: emphasis is on short-term risks to security of supply and global energy security. This energy security rhetoric aimed to legitimise more robust policy to exploit New Zealand's petroleum and mineral reserves. The politicisation of energy security has therefore lead to greater divergence in energy policy. This is problematic for the development of a coherent domestic and international policy approach to the challenges of climate change and the energy market. But politicisation has also meant the energy security remains a contested concept in policy debate. International policymakers and academics recognise that the concept of energy security needs to be re-evaluated in light of new challenges. Thus politicisation has helped stir a necessary debate in New Zealand. This debate challenges perceptions of energy security and policy, relative to the other pertinent energy, economic and environmental issues on the political agenda.

The Introduction is in four sections. The first section will explore energy security in international politics. It will show why it has been elevated to the top of governments' political agendas in recent times. First, the challenges of climate change and the global energy market are inexorably linked to energy security. Second, the concept of energy security needs to change in light of these challenges. Third, the way governments interpret energy security affects how they deal with the aforementioned challenges. Thus energy security is a highly politicised and debated concept. The second section will explore how energy security is referenced in New Zealand energy debate. It will establish that further investigation of the concept is needed as it is contested and its place in energy policy is not clear. On the basis of these two sections, the third section will briefly show how the Copenhagen School's Theory of Securitisation is appropriate for 
an analysis of energy security in New Zealand politics. Securitisation Theory analyses the processes and dynamics behind how issues are brought to the forefront of political agendas. Its framework will give a more in-depth understanding of how and why energy security has been interpreted in New Zealand politics and policy. The final section provides an outline of the thesis. It will reiterate the three central questions and show how they will be addressed by giving summaries of the arguments in each Chapter.

\section{Energy security in international politics}

Energy security is a highly politicised concept in recent times because of the twin challenges of climate change and shifts in the global energy market. ${ }^{1}$ When an issue is politicised it is brought to the forefront of political debate and prioritised in policy-formation. In the report Energy Security in Europe: proceedings from the Conference "Energy Security in Europe," it states that since 2006, the energy security and climate change nexus has been prioritised in political agendas across the world. ${ }^{2}$ This is because climate change injects much uncertainty in regards to the future of the energy system, and the nature of risks to this system. Alan DuPont argues that 'Climate change will complicate energy choices and heighten anxieties about future supplies of energy, particularly oil, as the transition from highly polluting fossil fuels to cleaner sources of energy gathers speed.'3

The invigorated international concern for energy security continues to the present day. For nations at the G20 summit in November, 2010, concerns over energy security were seen to be deepening because of increasing energy demand triggered by economic growth and a continued heavy dependence of this growth

\footnotetext{
${ }^{1}$ Bo Petersson and Barbara Tornquist-Plewa, "Energy Security in Europe: Proceedings from the Conference "Energy Security in Europe"'" (paper presented at the The CFE Conference papers, Lund, Sweden, 2008). P. 7

2 Ibid. p. 7

${ }^{3}$ Alan Dupont, "Climate Change and Security: Managing the Risk," Garnaut Climate Change Review(June 2008), http://www.garnautreview.org.au/CA25734E0016A131/WebObj/05Security/\$File/05\%20Secur ity.pdf. P. 17
} 
on fossil fuels. ${ }^{4}$ Two key drivers of market changes and concerns for energy security are China and India, ${ }^{5}$ whose rapid economic growth has spurred fears for the ability of the energy market to continue meeting this demand. ${ }^{6}$ As Nobuo Tanaka, Executive Director of the International Energy Agency (IEA) has noted: how China 'responds to the threats to global energy security and climate posed by rising fossil-fuel use will have far-reaching consequences for the rest of the world.' 7

Energy security remains a key concern in international climate change policy. In his remarks to the Climate Change Conference in Cancun, 7 December 2010, United Nations Secretary General Ban Ki-Moon stated that 'We will never assure energy security - or international security - without climate security.' ${ }^{8}$ In the regional context, on the 19 June 2010 the ninth meeting of the Energy Ministers of the Asia-Pacific Economic Cooperation (APEC) negotiated under the theme 'Low Carbon Paths to Energy Security. ${ }^{9}$ In 2007 at the East Asia Summit in Cebu, New Zealand as well as a number of other Association of South-east Asian Nations (ASEAN) member countries signed the Cebu Declaration on East Asian Energy Security. The declaration recognised the problems of the world supply of oil and

\footnotetext{
${ }^{4}$ Luo Laiming, "More Global Cooperation Needed to Ensure Energy Security: G20 Business Summit," Xinhua, http://english.cri.cn/6826/2010/11/11/2742s604462.htm.

${ }^{5}$ David G Victor and Linda Yueh, "The New Energy Order," Foreign Affairs 89, no. 1 (January/February 2010), http://www.foreignaffairs.com/articles/65897/david-g-victor-andlinda-yueh/the-new-energy-order. P. 1; Tsutomu Toichi, "Asian Energy Demand and Competition," in IISS-JIIA Asia's Strategic Challenges: In Search of a Common Agenda (Hotel Okura, Tokyo: The International Institute for Strategic Studies, 2-4 June 2008).; UPI, "Does Beijing Hold Key to Energy Security?," UPI.com(9 November 2010), http:/ / www.upi.com/Science_News/Resource-Wars/2010/11/09/Does-Beijing-hold-key-toenergy-security/UPI-76901289313937/.;Tsutomu Toichi, "First Session - Asian Energy Insecurity," in IISS-JIIA Conference "Asia Energy Demand and Competition" (Hotel Okura, Tokyo, Japan2 - 4 June 2008).;

${ }^{6}$ UPI, "Does Beijing Hold Key to Energy Security?." At the launch of the World Energy Outlook 2010, Nobuo Tanaka, the executive director of the IEA, stated that "[t]he energy world is facing unprecedented uncertainty [...]"

7 Ibid.

${ }^{8}$ Ban Ki-moon, "Remarks to Climate Change Conference (Unfccc Cop16 High-Level Segment) - as Delievered," un.org, http://www.un.org/apps/news/infocus/sgspeeches/statments_full.asp?statID=1028. 9 APEC, "Apec Energy Ministers Focus on Low-Carbon Energy Security," http://climate1.iisd.org/news/apec-energy-ministers-focus-on-low-carbon-energy-security/.
} 
unstable prices, as well as the urgent need to address global warming, and the previous agreement to enhance cooperation through promoting energy security. ${ }^{10}$

But the different rhetoric and approaches beg a central question: what is energy security and what makes it so politically important? First and foremost, energy security is important because it is a basic condition for a well-functioning economy and therefore in governments' political interests to maintain. In its World Energy Outlook 2007, the International Energy Agency (IEA) defined energy security as the '[...] adequate, affordable, and reliable supplies of energy.'11 Energy security is the reliable supply of energy to households, to businesses, and therefore is part of the staple diet for a well-functioning economy and the standard of living a nation enjoys.

The link between the economy and energy security is clear, and is reflected in governments' definitions of the term. In a report by the Economic Commission for Europe, energy security was proposed as 'the availability of usable energy supplies, at the point of final consumption, at economic price levels and in sufficient quantities and timelessness so that, given due regard to encouraging energy efficiency, the economic and social development of a country is not materially constrained.' ${ }^{12}$ Similarly, the Australian government defines energy security in its National Energy Security Assessment, as 'the adequate, reliable and affordable provision of energy to support the functioning of the economy and social development [...]'13 Energy security, it is implied, is not only connected to the economy but to the broader well-being of a nation.

\footnotetext{
${ }^{10}$ ASEAN, "Cebu Declaration on East Asian Energy Security," aseansec.org, http://www.aseansec.org/19319.htm.

${ }^{11}$ IEA, World Energy Outlook 2007: China and India Insights (Paris: International Energy Agency, 2007). P. 162

${ }^{12}$ Economic Commission for Europe, "Emerging Energy Security Risks and Risk Mitigation in a Global Context," in ECE Energy Series, ed. United Nations (New York and Geneva2007). P. 8 ${ }^{13}$ Australian Government, "National Energy Security Assessment 2009," (Canberra, Australia, 2009). www.ret.gov.au/energy/Documents/Energy\%20Security/National-Energy-SecurityAssessment-2009.pdf
} 
Something that threatens energy security therefore, has political implications. As Buzan et al. highlight '[p]atterns of employment and welfare expectation get rooted in domestic life of the nation and pose serious political problems when the economic conditions necessary for their maintenance disappear.'14 Governments have a vested interest in maintaining energy security and addressing energy security risks when they arise. For the most part these risks will not be brought to public attention until the lights do not turn on, or the petrol does not arrive at the pump. ${ }^{15}$ For instance, New Zealand faced extreme dry periods in 1992, 2001 and 2003, placing considerable pressure on electricity supply from the hydro-dams. This spurred the Clark Labour Government to implement national energy savings campaigns to reduce the risk of shortages. ${ }^{16} \mathrm{~A}$ more subtle response to energy security risks is found in the National Energy Efficiency and Conservation Strategy, made under the Energy Efficiency and Conservation Act 2000. Goal 5 of this strategy, according to Barry Barton, was 'to improve resilience to future energy supply disruptions and energy price shocks which was to be implemented through education rather than regulation. ${ }^{17}$

Energy security is also political because it spurs debate. This is particularly the case today, because energy security risks are more complex for policymakers to address. ${ }^{18}$ Thus new energy concerns have invigorated debate about what risks to energy security are and how they should be addressed in policy. Energy security has been traditionally defined as the adequate, reliable and secure

\footnotetext{
${ }^{14}$ Barry Buzan, Ole Waever, and Jaap de Wilde, Security: A New Framework for Analysis (Lynne Rienner Publishers, 1998). P. 20

${ }^{15}$ Dr. Richard Hawke, Interview, 2011

${ }^{16}$ Ministry of Economic Development, "Sustainable Energy - Summary," in New Zealand Government's Sustainable Development Programme of Action (Wellington2004). p. 3; see also Barry Barton et al., Energy Security: Managing Risk in a Dynamic Legal Environment (New York: Oxford University Press, 2004). P. 373 - 374

${ }_{17}$ Barry Barton et al., Energy Security: Managing Risk in a Dynamic Legal Environment. P. 377

${ }_{18}$ Economic Commission for Europe, "Investing in Energy Security Mitigation," in Energy Series, ed. United Nations (New York and Geneva2008). P. 1; Joan MacNaughton, "Cooperating on Energy Policy: The Work of the International Energy Agency," in The New Economic Diplomacy: Decision-Making and Negotiation in International Economic Relations, ed. Nicolas Bayne; Stephen Woolcock (Burlington, USA: Ashgate, 2007). P. 293.; Dieter Helm, "Energy Policy: Security of Supply, Sustainability and Competition," Energy Policy 30, no. 3 (February 2002). p. 182.
} 
supply of energy, ${ }^{19}$ but this simple definition has been criticised by scholars and policymakers as insufficient for today's world. First, the simple definition entails a narrow perception of risks to the energy system. As Philip Andrews-Speed and Anthony Froggatt argue, terms of reliability, or similar, reflect the threat of disruption to supply, and affordable reflects the potential macroeconomic effects of sudden price spikes. ${ }^{20}$ The World Economic Forum (WEF) Global Agenda on Energy Security however, states that energy security is 'the reliable, stable and sustainable supply of energy at affordable prices and at an acceptable social cost.' ${ }^{21}$ Linda Yueh argues that this captures risks and issues, environmental and other, that are 'inexorably linked with those of energy.'22 Likewise, the RSIS Centre for Non-Traditional Security (NTS) argued that among the traditional tenet of the economy and security of supplies, environmental and socio-political issues add to new concerns to be addressed. ${ }^{23}$ On the other hand, most recently and more broadly, Vlado Vivoda argued that the concept of energy security must change in order to meet new challenges in the Asia-Pacific region, and likewise John V. Mitchell called for similar in the European context. ${ }^{24}$

The politics of energy security emerges from the question of how governments will manage the complexity of economic growth, climate change, and the recognition of how a government deals with energy is at the centre of both. This recognition was evident during the 2005 UK Prime Minister's presidency of the

\footnotetext{
${ }^{19} \mathrm{Xu}$ Yi-Chong, "China's Energy Security," in Energy Security in Asia, ed. Michael Wesley (New York: Routledge, 2007). p. 42

${ }^{20}$ Philip Andrews-Speed, "Energy Security in East Asia: A European View," in Symposium on Pacific Energy Cooperation 2003 (Tokyo2003). P. 2; Antony Froggatt and Michael A Levi, "Climate and Energy Security Policies and Measures: Synergies and Conflicts," International Affairs 85, no. 6 (2009). P. 6

${ }^{21}$ Linda Yueh, "An International Approach to Energy Security," Global Policy 1, no. 2 (May 2010).p. 216

22 Ibid. p. 216

${ }^{23}$ RSIS Centre for Non-Traditional Security Studies, "Executive Summary," in RSIS-NTS Workshop on Nuclear Energy and Human Security

(Traders Hotel, Singapore: S. Rajarantnam School of International Studies, 23 April 2010). P. 1; Daniel Yergin, "Ensuring Energy Security," Foreign Affairs 85, no. 2 (2006). P. 69

${ }^{24}$ J. V. Mitchell, "Energy Supply Security: Changes in Concepts," in Seminaire Europeen sur la Securite d'approvisionnement Energetique

(Paris Ministry of Economy, Finance and Industry, 2000).; John V. Mitchell, "Renewing Energy Security," The Royal Institute of International Affairs: Sustainable Development Programme (July 2002).
} 
G8 and cooperation with the IEA, in which energy was placed at the heart of the climate change agenda. ${ }^{25}$ This reflects Anthony Giddens argument that "[i]t is certainly vital to relate the climate change debate to that over energy security, where again the state has a prime part to play." 26 It is no surprise then that energy security would be referred to more frequently by world leaders and officials in both international climate change, as well as institutions and forums dealing with global economic concerns. First, debating energy security and climate change invites thoughts about how energy is consumed and the effects of this process. The use of fossil fuels supports modern economies but also contributes to greenhouse gas emissions, thereby exacerbating the risks of climate change. Second, addressing risks to energy security implicitly involves addressing risks to the economy. And in this current environment, addressing such risks naturally encompasses issues associated with the global energy market. These issues include whether the world will have enough energy to meet future demand, and whether meeting this demand can be achieved while addressing climate change. So, how does energy security play out in New Zealand politics? How are energy security risks presented and addressed in national policy?

\section{Energy security in New Zealand politics}

New Zealand government departments refer to energy security in policy documents, as do politicians and bureaucrats in speeches and media releases. The Ministry of Economic Development's (MED) New Zealand Energy Strategy released in 2011 (NZES 2011), states that 'High standards of energy security are critical to New Zealand's economic performance and social wellbeing particularly in relation to oil and electricity. ${ }^{27}$ It does not give a clear definition of what energy security is. However, it does suggest how energy security is

\footnotetext{
${ }^{25}$ MacNaughton, "Cooperating on Energy Policy: The Work of the International Energy Agency." P. $288-289$.

26 Anthony Giddens, "The Politics of Climate Change: National Responses to the Challenges of Global Warming," www.policy-network.net(September 2008). p. 15

${ }^{27}$ Ministry of Economic Development, "New Zealand Energy Strategy 2011 - 2021: Developing Our Energy Potential," (Ministry of Economic Development, 2011). P. 12
} 
achieved, and how it is enhanced by different policy measures. This includes diversifying resources and maintaining a resilient energy infrastructure that can cope with shocks, change or supply disruptions. ${ }^{28}$

In the Ministry of Foreign Affairs and Trade, the New Zealand Ambassador to Climate Change Jo Tyndall stated in a speech delivered at the University of Otago, that '[r]ather than economic development at all costs, the watch-word seems to be sustainable economic development. Food security, energy security, and water security are three fundamental priorities for all governments around the world.' ${ }^{29}$ In an opening address to the New Zealand Petroleum Conference in September 2010, the Minister for Energy and Resources Hon Gerry Brownlee stated that significant deposits of hydrates 'could provide either a long term underpinning of energy security for the country $[\ldots]^{\prime 30}$ Prior to the election of the John Key's National government, Brownlee stated as National Party energy spokesperson, that a 'National-led Government will maintain an unrelenting focus on security of energy supply.' ${ }^{31}$ The Ministry for the Environment, in a discussion paper on Measures to Reduce Greenhouse Gas Emissions in New Zealand Post-2012, stated that it was in New Zealand's national interest to pursue GHG emissions reductions for the co-benefits of 'economic development, energy security and local environmental gains.' ${ }^{22}$ Energy security evidently is linked to the New Zealand economy and has a clear relationship with reducing greenhouse gas emissions (GHGs).

\footnotetext{
28 - - - , "New Zealand Energy Strategy 2011 - 2021: Developing Our Energy Potential," (Ministry of Economic Development, August 2011).p. 13

${ }^{29}$ Jo Tyndall, "Global Collaboration Towards Sustainability and Climate Change," in PIM Conference (University of Otago: business.otago.ac.nz, 11 November 2010).

${ }^{30}$ Hon Gerry Brownlee, "Opening Address to the New Zealand Petroleum Conference" (paper presented at the Petroleum Conference, 20 September 2010).

31 Hon. Gerry Brownlee, "Security Underlines National's Energy Policy," national.org.nz, http:/ / www.national.org.nz/Article.aspx?ArticleID=28380.

${ }^{32}$ Ministry for the Environment, "Discussion Paper on Measures to Reduce Greenhouse Gas Emissions in New Zealand Post-2012," mfe.govt.nz, http:/ / www.mfe.govt.nz/publications/climate/discussion-paper-post-2012$\mathrm{dec} 06 / \mathrm{html} /$ page3.html.
} 
Energy security was also referred to under the Clark Government, particularly in the New Zealand Energy Strategy released by MED in October 2007 and by the Hon David Parker. Hon David Parker, as both Minister for Energy and Minister Responsible for Climate Change issues, referred to energy security in his speeches and public addresses. In an address to the Hampden Energy Future Forum in 2006, Parker spoke of peak 'cheap' oil and energy security concerns that oil will run out or get more expensive, but stated that 'While the Government is concerned about threats to oil security, we don't expect it to run out.' 33 Second, the 'Government believes the more serious and more immediate problem is climate change.' 34 Then in a speech to the Electrical Engineers Association Conference in 2007, Parker stated that 'Energy security is, of course, paramount, and renewable energy has a vital part to play; expressing the desire to provide more regulatory certainty for renewable energy. This was to be achieved through finalising the NZES 2007 and preparing a National Policy Statement, as well as 'making greater use of the Minister for the Environment's call-in power.' 35 Evidently in the Clark Government, as is also the case with the Key National Government, energy security is linked to the economy and reducing greenhouse gas emissions, and a more robust role of government in the energy sector.

The NZES 2007 and 2011 refer to the challenges of energy security and climate change in slightly different ways. The NZES 2011 refers to these challenges in the global context, and in particular, states that New Zealand can contribute to global energy security through the development of petroleum resources. ${ }^{36}$ The NZES 2007 does not, and tends to identify energy security and climate change as two challenges that the Clark Government would provide leadership on. ${ }^{37}$ The NZES

\footnotetext{
${ }^{33}$ David Parker, "David Parker Speech: The End of Cheap Oil," Scoop.co.nz, http://www.scoop.co.nz/stories/PA0611/S00004.htm.

34 Ibid.

${ }^{35}$ Hon. David Parker, "Speech to Electrical Engineers Association Conference 2007," beehive.govt.co.nz, http://www.eea.co.nz/Attachment?Action=View\&Attachment_id=447. ${ }^{36}$ Ministry of Economic Development, "New Zealand Energy Strategy 2011 - 2021: Developing Our Energy Potential." P. 3

37 - - - , "New Zealand Energy Strategy to 2050: Powering Our Future," (Ministry of Economic Development, October 2007). P. 5
} 
2007 also stated that in the development of the strategic direction of $\mathrm{New}$ Zealand's energy system, 'we have weighed up a number of important considerations. Two major issues are energy security and climate greenhouse gas emissions.' 38 The energy costs impacted on by different choices were also included in the formation of the strategy. Clearly the Clark Government considered energy security an important issue for consideration in developing energy strategy. The Key Government also perceives energy security as an important issue as well as global energy security. These issues will have a role in policy-formation.

Current foreign policy does not reference global energy security in the same way as the NZES 2011. This is another difference between the two Governments' approaches to energy security. Where energy security was present in the Statement of Intents released by the Ministry of Foreign Affairs and Trade (MFAT) under the Clark Government, any similar references are absent in current strategy. In the Clark Government, foreign policy presented climate change and energy security as key concerns for the regional architecture of the Asia-Pacific. The White Paper entitled Our Future with Asia, released in 2007, argued that the region was becoming more concerned with results of economic growth and success. This included references to growing resource competition which include both energy and environmental problems, adding that ' $\mathrm{t}] \mathrm{he}$ challenges of dealing with climate change and energy security are becoming priority areas for Asian countries, and New Zealand has a stake in how the region deals with these issues." 39 MFAT's Statement of Intent 2007 highlighted the global issue of energy security several times in reference to dominant trends, where ' $[t]$ he integration of worldwide markets for labour, goods, services, capital, and technology is quickening, with increasing competition for natural resources and energy security.' 40 This is mentioned in conjunction with rapid economic

\footnotetext{
${ }^{38}$ Ibid. p. 27

${ }^{39}$ Ministry of Foreign Affairs and Trade, "Our Future with Asia," (Wellington2007). P. 26

$40--$, "Statement of Intent 2007-2010 Incorporating the Forecast Financial Statements for 2007/08," (Ministry of Foreign Affairs and Trade,, 2007). P. 14
} 
development of China and India, and the accelerating pace of economic and political integration at the regional level, especially in the Asia-Pacific. These trends place pressure on countries, especially New Zealand, 'to be more globally active and equipped to respond to a rapidly changing and less predictable world.' ${ }^{41}$ Energy security is also mentioned in regards to sustainability and climate change. ${ }^{42}$ In this respect, the domestic energy strategy was consistent with the foreign policy agenda.

Energy security in New Zealand is referred to in a variety of instances, as part of energy policy and dialogue, or presented publicly to different audiences by different government actors. It has a role in political discourse and policy formation. There are subtle differences, however, between the Labour-led and National-led energy policies, and there has also been heated debate. One difference shown here is that the NZES 2007 identified energy security and climate change as issues to be addressed, with a focus on climate change and a push for policy on renewable energy. The NZES 2007 was criticised by '[s]ome major energy users and other business interests [who] believed the draft strategy was too weighted towards climate change, at the expense of security of supply and economic growth [...]'43 The current NZES 2011 does identify energy security as a challenge and a priority area that will help achieve the government's goal of economic growth. ${ }^{44}$ Second, the NZES 2011 makes reference to the contribution New Zealand can make to global energy security by the development of both renewable and non-renewable resources.

The debate is clearly continuing: this is evident in debate between Labour and National MPs on previous and current energy strategy. This debate is not just a question of approaches to energy security, but also about what risks to energy security they perceive are the most important and how they can be addressed in

\footnotetext{
41 Ibid. P. 14

42 Ibid. p. 15;

${ }^{43}$ Ministry of Economic Development, "New Zealand Energy Strategy to 2050: Powering Our Future." P. 9

44 _ - - , "New Zealand Energy Strategy 2011 - 2021: Developing Our Energy Potential." P. 1
} 
policy. Hon Gerry Brownlee argued that 'Improving energy security and energy affordability are key concerns [...] In my view, these issues were not accorded a sufficiently strong priority in the 2007 NZES.' 45 Comparatively the current Labour spokesperson for energy Charles Chauvel, argues that National is failing to set clear priorities in the energy sector as well as make energy security and affordability priorities. ${ }^{46} \mathrm{He}$ also argues that an incoming Labour-led Government will reissue a detailed New Zealand Energy Strategy built on current and previous strategy, but specifying 'that domestic energy security is of cardinal importance, to be achieved bearing in mind the twin imperatives of affordability to consumers; and the need to fully maximise our renewable advantage.' 47

This thesis will show that energy security has been politicised in New Zealand politics. In doing so, I will show that the Clark and Key Governments interpret and present energy security risks in different ways. I will argue that this is because of, and is driven by, distinct priorities in their political agendas. Second, that it this not simply a disagreement between the Key Government and the Labour Opposition over how best to address risks to the energy system, but at the core are different perceptions of energy security. Key stakeholders and market participants also have divisive views on energy security. The two governments structured two different rhetorical politicisations to appease their constituencies, and to prioritise energy security issues that support their policy initiatives. Thus politicisation has led to divergence in New Zealand's energy policy. This is problematic because it creates political uncertainty in the domestic energy market. This could be used to stall the development of climate change policy. Alternatively, politicisation of energy security is good because it stirs

\footnotetext{
${ }^{45}$ Hon Gerry Brownlee, "Government Consulting on Energy Policy," www.med.govt.nz, http:// www.med.govt.nz/templates/Page__44122.aspx.

${ }^{46}$ Charles Chauvel, "No-Show Brownlee's Got No Plan," labour.org.nz, http://www.labour.org.nz/news/no-show-brownlee\%E2\%80\%99s-got-no-plan. 47 _ - , "Energy and Resources Policy in New Zealand: Where's the Plan?," labour.org.nz, http://www.labour.org.nz/news/energy-and-resources-policy-new-zealandwhere $\%$ E2\% $80 \% 99$ s-plan.
} 
debate on what risks to the energy system are. This is highly relevant given how the international energy debate has been unfolding.

\section{The Copenhagen School Theory of Securitisation}

I will argue that the Copenhagen School Theory of Securitisation provides the necessary framework to analyse how energy security has been politicised in New Zealand. The Copenhagen School understands that actors use security rhetoric to raise the salience of an issue on the political agenda. Furthermore, by using security rhetoric, an actor argues that the issue needs to be governed within or above politics. This process can result in different outcomes that are dependent on context. First, the Copenhagen School Theory of Securitisation argues that security is an inter-subjective process and socially constructed. ${ }^{48}$ Second, they argue that the language of threat and risk are inherent to political processes that construct ideas about security. Actors invoke the language of threat in order to present an issue as a case of some urgency and survival, and to argue that it should be prioritised above other issues. ${ }^{49}$ Actors can frame these issues in different ways, for instance, in environmental, economic or military terms. Finally, given the right conditions, the risk presented by the actor may be accepted by an audience and acted upon within or above politics.

This thesis also seeks to examine how energy security risks are presented and how they affect the process of energy policy formation. Securitisation Theory in this respect, argues that the language of threat, risk or vulnerability, has tactical appeal. The language of threat is used to elevate an issue to the top of the political agenda, to encourage the issue be prioritised and addressed within or above politics. Security is as much about the art of persuasion, convincing another of the saliency of an issue, as it is about traditional-military understanding of conflict. Buzan et al. distinguish themselves from the

\footnotetext{
48 Buzan, Waever, and Wilde, Security: A New Framework for Analysis. p. 57, 197, 31

${ }^{49}$ Holger Stritzel, "Towards a Theory of Securitisation: Copenhagen and Beyond," European Journal of International Relations 13, no. 357 (2007). P. 360
} 
traditionalist agenda of security studies by arguing that a successful securitisation can never only be imposed through coercion, that 'there is some need to argue one's case. ${ }^{50}$ Or in other words, a securitising actor must convince another that an issue is threatening enough to survival that it requires the violation of rules and normal political procedure, by emergency action. ${ }^{51}$ This of course does not just mean that an issue is addressed through emergency action only. An issue can be politicised, that is to say, it is given priority in political debate and governed through policy initiatives.

On these theoretical foundations Securitisation Theory identifies the who, what, where and how of a security concept, and yields a more in-depth understanding of risk perceptions in political debate and how these risks are responded to in policy. ${ }^{52}$ Securitisation Theory can therefore unpack how risks are presented in New Zealand politics and give a detailed analysis on the political debate on energy security.

This thesis will apply Securitisation Theory to energy security in New Zealand energy politics and policy. I am interested in the politics of energy security, particularly how strategies of politicisation have affected the formation of energy policy in New Zealand. I will therefore analyse key energy policy documents, reports, discussions and, speeches and media releases by relevant politicians and bureaucrats, news articles in the New Zealand media, as well as broader political dialogue on energy policy between government and their audience: key stakeholders. Key stakeholders include those involved in the energy sector, such as companies, associations, community groups, councils and individuals, as well as political parties. This thesis will also be informed by face-to-face discussions with politicians, bureaucrats and academics that are involved in energy policy or specialise in New Zealand energy security and policy. Labour MP David Parker

\footnotetext{
${ }^{50}$ Buzan, Waever, and Wilde, Security: A New Framework for Analysis. p. 25

51 Ibid. p. 57, 197, 31

52 Felix Ciuta, "Security and the Problem of Context: A Hermeneutical Critique of Securitisation

Theory," Review of International Studies, no. 35 (2009). P. 301
} 
will be interviewed in regards to his role as Minister of Energy in the development of the NZES 2007. Unfortunately current Ministers under the National Government were sought but unable to be contacted. These included the acting Minister for Energy and Resources Hon Hekia Parata, and Hon Dr Nick Smith, Minister for Climate Change Issues. Dr Richard Hawke, the Manager of Energy and the Environment in the Ministry of Economic Development was able to be interviewed, as was Stuart Calman, Director of Climate Risk and Policy in the Ministry for the Environment. Key energy security academics in New Zealand, Professor Barry Barton from University of Waikato and Professor Ralph Sims from Massey University were also spoken with.

\section{Outline}

Has energy security been politicised in New Zealand? If so, how has it been politicised? Has politicisation of energy security helped or hindered energy policy formation? This thesis seeks to explore these questions across the following five chapters. Chapter Two will discuss what has been written on energy security in New Zealand politics. It will show that there is a major gap in critical analysis on this topic. It will argue that the Copenhagen School's Theory of Securitisation can help us unpack the meaning of energy security by examining how it is referred to, by whom, and in what context. I argue the language of risk, threat and vulnerability continues to have its appeal in political debate on energy issues, where actors emphasise some risks over others in support of their policy objectives. The extent to which these risks are prioritised in substantive energy policy is the process of politicisation. This is relevant, in particular, to unpacking the current debate on energy security and climate change in New Zealand politics.

Chapter Three will then apply this understanding of Securitisation Theory to how energy security was politicised in the Clark Labour Government's New Zealand Energy Strategy to 2050: Powering our future. The chapter will argue 
that the Clark Government used a strategy of politicisation to bring energy security risks onto the political agenda. The rhetoric of this politicisation sought to legitimise its robust climate change policy. I will show this by highlighting the features of its security argument used to promote its particular views on energy security risks and climate change policy. I will also show that this evident politicisation of energy security and climate change was consistent through government departments; demonstrative of a broader attempt to institutionalise a whole-of-government approach to energy security and climate change issues.

Chapter Four will analyse the current New Zealand Energy Strategy 2011 - 2021: developing our energy potential. The chapter will show that energy security is referred to in a dramatically different way to the Clark Labour Government. The Key Government uses energy security rhetoric to legitimise the development of New Zealand's petroleum and mineral resources. The rhetoric clearly shows a different conceptualisation of risk: energy security risks are not articulated using a security argument. Energy security is spoken in terms of security of supply subsumed to economic growth concerns. Furthermore, New Zealand's role in contributing supply to meet the growing global demand for energy is another feature of its argument. Market processes are emphasised and coupled with more centralised approach to energy security in the Ministry of Economic Development, with the omission of the term from key foreign policy documents and activities. The Key Government uses a strategy of politicisation to legitimise robust policy on resource development for global and domestic energy security. This is in distinct comparison to the Clark Government's policy focus on domestic and global leadership on climate change, and renewable resources.

Chapter Five will explore the key reasons why this dramatic shift has occurred. It will argue that it is because of the open-ended nature of politicisation combined with three key factors; the formative stage of energy policy in New Zealand, divisive constituency views of energy security as well as domestic and international conditions. As a result, two distinct rhetorical arguments for energy 
security have been used to legitimise the Key and Clark Government energy policies. First, the chapter will show how the incumbent government has a strong influence on the direction of policy and how, institutionally, energy security issues will be addressed. Second, it will show how the Clark and Key Governments faced opposition to, and constituency support for, their respective energy strategies. This divisive energy security discourse, combined with contextual economic and political factors, form the resonating conditions which have shaped the distinct policy responses to energy security. Politicisation is an open-ended process. Thus the Key Government adopted energy security from the Clark Government, and easily shaped an entirely different rhetoric in defence of its distinct energy strategy.

The discussion in Chapter Six will summarise the analysis of the previous chapters and evaluate the consequences of the findings. It will suggest that while politicisation has given salience to energy security it has also lead to clear divergence in energy policy. The politics of energy security demonstrate that the nature and level of risks are indeed contested. The Clark Government identified risks to the energy system that the government would respond to through climate change policy. The Key National Government's current strategy gives a clear signal that the energy market will respond to particular international trends: growing global demand for energy. This divergence, coupled with resonating conditions that were not ideal for the Clark Government's politicisation of energy security, meant that politicisation has not been entirely successful towards the development of a coherent policy response to energy issues. Political uncertainty remains over New Zealand's energy policy. The institutionalisation of a coherent domestic and international policy approach to energy security and climate change has also been limited. Granted, politicisation will hopefully mean that the issue remains contested and debated. The worst for New Zealand politics would be a stagnant energy debate given the international energy challenges the country will continue to face. 


\section{Chapter Two}

\section{Energy Security and the Copenhagen School Theory of Securitisation}

It is clear that energy security has an important place in international debate on climate change and energy market concerns. Energy security also has a place in New Zealand energy policy, but exactly what place it holds is not clear. Furthermore, Labour and National politicians appear to perceive energy security differently. Has it been politicised and how? If politicians or bureaucrats present energy security risks in different ways, what does this mean for New Zealand's response to complex energy challenges? Does the politicisation of energy security help or hinder this process? There is a substantial gap in the energy security and New Zealand politics literature that directly addresses these issues. At present the literature focuses on what energy policy options are available rather than analysing how energy security has been understood and addressed in New Zealand politics.

This chapter will show how the Copenhagen School Theory of Securitisation can be used to analyse energy security in New Zealand politics. Previous research on energy security has taken the term's meaning for granted; as something objective in New Zealand. First, the securitisation framework of analysis can be used to examine how energy security risks are presented in New Zealand politics. The international literature shows that the language of threat, risk or vulnerability has been used in politics to bring energy issues to the fore of policy debate. When the issue is successfully brought to the debate, and made a part of policy, this is a politicisation. What risks have been prioritised in current and previous energy policy in New Zealand? How has energy security been politicised in New Zealand? Second, international literature also shows that energy security risks have been politicised and linked to the urgency to address climate change. Securitisation Theory can identify if this has occurred in New Zealand politics, as 
it understands that issues can be viewed through different lenses; as environmental, economic or military issues. Energy security can be at once viewed as both an environmental issue (where it contributes to climate change) or an economic issue concerned with disruptions to energy supply. Have energy security risks been linked to New Zealand's climate change debate, or do they remain separate to these concerns?

\section{New Zealand literature review}

For a concept that is increasingly part of the political lexicon, there has been a striking lack of research on the meaning of energy security in New Zealand. What research does exist tends to explore energy policy options rather than embarking on a critical examination of New Zealand's concept of energy security and its place in politics. Two texts however, have engaged with this topic. First is Energy Security: The Foreign Policy Implications, edited by Brian Lynch, and second, Barry Barton's analysis of New Zealand's energy security concerns and policy entitled Reaching the Limits of What the Market Will Provide: Energy Security in New Zealand. The former analyses future energy policy options, the latter outlines New Zealand's national approach to energy in policy. Some external factors of energy security are explored in Energy Security, for example, the Asia-Pacific's increasing dependence on crude oil from the Middle-East with reflections on the region's volatility and the possibility of oil supply disruptions. New Zealand's foreign policy position or diplomacy options however, are not explored. ${ }^{53}$ This reflects the general tenor of the contributions which focus on domestic energy policy (such as the development of resources) rather than a critical study on what energy security actually is by analysing where and how it is referred to in politics. ${ }^{54}$

\footnotetext{
53 Brian Lynch, ed. Energy Security: The Foreign Policy Implications (Wellington: New Zealand Institute of International Affairs,2008). p. 13 - 17

${ }^{54}$ See David F.S Natusch, "New Zealand's Energy Reserves as Strategic Assets," in Energy Security: The Foreign Policy Implications, ed. Brian Lynch (Wellington: The New Zealand Institute of International Affairs, 2008). p. 59
} 
The meaning that energy security bears in politics has not been explored in New Zealand research. This can be explained by the fact that energy security has not had a strong role in legislation or policy in New Zealand. In Reaching the Limits of What the Market Will Provide: Energy Security in New Zealand, Barry Barton notes the lack of legal provision for the concept in New Zealand, but adds that energy security 'problems' exist despite this and whatever the policy mix. ${ }^{55}$ Basically, New Zealand will never have comprehensive energy security, especially in regards to oil imports and the associated risks which are 'largely out of the control of a small country. ${ }^{56} \mathrm{New}$ Zealand is exposed to international energy markets, and government simply has no power over the price or supply of energy from these markets. The other major text, Energy Security: The Foreign Policy Implications, is interested in how other states perceive energy security and how they act on it. Brian Lynch states that the interest of the New Zealand study was to 'examine the constellation of factors that comes into play $[\ldots]$ and specifically those that propel a country's efforts to ensure that it has continued access to a reliable and affordable supply of energy, in one or more of its forms. ${ }^{57}$ However, no study has analysed the evident debate on energy security in New Zealand. Nor have the risk perceptions of energy security been analysed, or how these perceptions are shaping energy policy.

This chapter will elaborate on how Securitisation Theory can unpack New Zealand's energy security debate in three sections. The first section will show how energy security is a highly subjective concept. This makes the Copenhagen School relevant given its understanding of security as inter-subjective and socially constructed. The second section will highlight how security arguments have been used in the climate change and energy security debate. Risk perceptions are therefore highly important to understand because they shape the

\footnotetext{
${ }^{55}$ Barry Barton et al., Energy Security: Managing Risk in a Dynamic Legal Environment (New York: Oxford University Press, 2004). P. 389

56 Ibid. P. 389

${ }^{57}$ Lynch, ed. Energy Security: The Foreign Policy Implications. P. 7
} 
policy debate on how best to respond energy security and climate change concerns. Securitisation Theory can be used to analyse how energy security risks are presented by political actors in New Zealand, with consideration of the domestic policy environment. The third section will argue that politicisations of energy security risks are tactical moves that have real effects in politics and energy policy formation. Securitisation Theory can gauge whether energy security has been politicised in New Zealand and the effect this has had on energy policy formation.

\section{Risk perceptions and energy security theory}

The Copenhagen School Theory of Securitisation is based on an understanding that security is inter-subjective and socially constructed..$^{58}$ This makes the theory highly applicable to an analysis of energy security in New Zealand politics. First, it is commonly understood by scholars that meaning attributed to the term is highly subjective and context-dependent. As noted previously, the International Energy Agency (IEA) define energy security as the '[...] adequate, affordable, and reliable supplies of energy. ${ }^{59}$ Yet according to Stuart Harris what is reasonable or affordable is more complicated. ${ }^{60}$ For these reasons also, scholars such as Terence O'Brien argue that the meaning of energy security must be understood as context-bound and dependent. ${ }^{61}$ Perspectives on energy security will differ depending on different actors' position in the 'value-chain' - as exporters or importers, business or policy-makers, developed or developing nations. Thus concerns for energy security can involve different geopolitical tensions, market

\footnotetext{
${ }^{58}$ Buzan, Waever, and Wilde, Security: A New Framework for Analysis. p. 57, 197, 31

${ }^{59}$ IEA, World Energy Outlook 2007: China and India Insights. P. 162

${ }^{60}$ Stuart Harris and Barry Naughten, "Economic Dimensions of Energy Security in the AsiaPacific," in Energy Security in Asia, ed. Michael Wesley (New York: Routledge, 2007). P. 184

${ }^{61}$ Petersson and Tornquist-Plewa, "Energy Security in Europe: Proceedings from the Conference "Energy Security in Europe"'".p. 227; Helm, "Energy Policy: Security of Supply, Sustainability and Competition." p. 173; Chang Youngho, "Powering Growth: The Non-Traditional Security (N.T.S) Perspective on the Energy Security Policies in Singapore," in Asia Security Initiative Policy Series: Working Papers, ed. RSIS Centre for Non-Traditional Security Studies (Singapore: S. Rajaratnam School of International Studies, June 2010). p. 1; Yergin, "Ensuring Energy Security."; Lynch, ed. Energy Security: The Foreign Policy Implications. p. 69
} 
structures, and energy infrastructure, to name but a few. ${ }^{62}$ This means that actors will attribute meaning to energy security in different ways, thereby perspectives of risks are equally subjective.

The politics of energy security is as such a debate on the nature and level of risks to the energy system. Security, and risks to security, are in part a question of perception, ${ }^{63}$ and the number of actors that can have different views on energy security is broad. In the International Institute for Strategic Studies (IISS) Transatlantic Dialogue on Climate Change and Security, hosted in 2010, the language of threat was used by participants in the debate to emphasise different risks to energy security and climate change. On one hand it was argued that climate change directs threats to energy security, especially to existing energy infrastructure that can be damaged by natural disasters. ${ }^{64}$ On the other hand, it was also argued that the United States' dependence on energy imports, especially petroleum resources, presented a serious threat to security because it weakens international leverage and exposes the U.S. to hostile regimes. ${ }^{65}$ In the same debate, another argued that portraying climate mitigation policies as ways to increase energy security is a wilful manipulation of the public. ${ }^{66}$ Naturally, these different perceptions have raised debate about what energy security is and how it should be addressed.

Securitisation Theory can help understand the level of debate on energy security risks in New Zealand. Securitisation Theory identifies when the language of threat is used in New Zealand politics to prioritise an issue in energy policy. The

\footnotetext{
${ }^{6}$ World Economic Forum and Cambridge Energy Research Associates, "The New Energy Security Paradigm," in World Economic Forum: Energy Vision Update (Geneva: World Economic Forum, Spring 2006). p. 7; See also APERC, "Apec Energy Overview 2009," (The Institute of Energy Economics, Japan, 2010).

${ }^{63}$ Harris and Naughten, "Economic Dimensions of Energy Security in the Asia-Pacific." P. 184 See also, Michael Wesley, Energy Security in Asia (New York: Routledge, 2007). p. 4 - 5

${ }^{64}$ Andrew Holland, "Climate Change and Energy Security: Overlapping Priorities," in IISS

Transatlantic Dialogue on Climate Change and Security (Hyatt Regency Capitol Hill, Washington,

D.C.: International institute for Strategic Studies, 16 March 2010). p. 5

65 Ibid. p. 5

${ }^{66}$ Ibid. p. 5, 6
} 
Copenhagen School refers to this as a securitising move: a political actor argues (using threat language) that an issue is a case of some urgency or survival, and that it should, therefore, be prioritised. ${ }^{67}$ The Copenhagen School's method has also been criticised by scholars, particularly in regards to the language of threat. For instance, Matt McDonald highlights that the nature of the speech act (which embodies a securitising move) is too narrowly defined by the designation of threat. ${ }^{68}$ Holger Stritzel argues that basing analysis on an existential threat alone does not take into account how security practices can relate to threats which are not explicitly a case of survival. ${ }^{69}$ This is particularly the case in energy security and climate change debates.

An example of an immediate energy security threat that invoked a strong policy response is the Arab Oil Crisis of 1973/74, and 1979, in which Petroleum Exporting Countries (OPEC) reduced oil supplies to particular countries through embargo action. ${ }^{70}$ The International Energy Agency was established to respond to these disruptions, and coordinate member states' energy policy to mitigate the effects of another oil disruption to their economies. New Zealand is one of these member states. This is a security argument that is not based on existential threat alone, but formed on the economic significance of the oil crisis and international mobilisations of states. The New Zealand Energy Strategy of 2011 referenced New Zealand's continued fulfilment of its International Energy Agency obligations that hedge against another serious international oil supply disruption. ${ }^{71}$ It is clear that the referent object is the New Zealand economy which is vulnerable not only to price increases but also 'external disruptions to

\footnotetext{
${ }^{67}$ Stritzel, "Towards a Theory of Securitisation: Copenhagen and Beyond." p. 360

${ }_{68}$ Matt McDonald, "Securitisation and the Construction of Security," European Journal of International Relations 14, no. 563 (2008). p. 563

${ }^{69}$ Stritzel, "Towards a Theory of Securitisation: Copenhagen and Beyond." p. 367; Ciuta, "Security and the Problem of Context: A Hermeneutical Critique of Securitisation Theory."

70 MacNaughton, "Cooperating on Energy Policy: The Work of the International Energy Agency." p. 280

${ }^{71}$ Ministry of Economic Development, "New Zealand Energy Strategy 2011 - 2021: Developing

Our Energy Potential." p. 13
} 
oil supply.' 72 This warrants the government to allocate funds to continue purchasing oil stocks, and have a national emergency response strategy in place in case of another oil disruption. The effects of oil disruptions were clear enough for states to mobilise and form the International Energy Agency, and agree on collective policy to hedge against any future risk.

A security argument is often applied to energy and climate change issues using the language of threat, but the threat is not necessarily exceptional or an explicit case of immediate survival. For instance, Barry Barton argues that energy security issues can vary by the nature of the threat where short-term natural disasters are one form of threat to security, as are longer-term droughts and changes in climate. ${ }^{73}$ Particularly in the latter case, the threat is not an explicit case of immediate survival. Nevertheless as in the case of climate change, longterm threats can be couched in a security argument. The most explicit example of a securitising move made by an actor in the climate change debate is the rhetoric of the President of the Republic of Maldives, Mohamed Nasheed. In September 2009 he stated that 'For the Maldives, climate change is no vague or distant irritation but a clear and present danger to our survival [...] we need emergency action all around the world to curb emissions.' ${ }^{74}$ This is a highly political invocation of a security argument as it emphasises threat, survival and the urgency for the issue to be addressed. This does not necessarily mean that action takes place: the emergency mobilisation or all states to address climate change has simply not occurred. So what makes a security argument successful? What other results can these arguments, applied to energy and climate change issues, have in politics?

72 - - - , "New Zealand Energy Strategy: Developing Our Energy Potential and the New Zealand Energy Efficiency and Conservation Strategy," (Wellington: Ministry of Economic Development,, 2011). p. 12

${ }^{73}$ Barton et al., Energy Security: Managing Risk in a Dynamic Legal Environment. p. 10

74 Mohamed Nasheed, "Climate Change Requires a Real Movement,"

http://www.huffingtonpost.com/mohamed-nasheed/climate-change-requires-a_b_292747.html. 


\section{Securitising moves: who, how and where?}

Clearly securitising moves take place in different contexts, by different actors and will have different results. In his State of the Union address in January, 2007, President George W. Bush stated that it was in the interest of the U.S. to diversify its oil supply: '[f]or too long our Nation has been dependent on foreign oil. And this dependence leaves us more vulnerable to hostile regimes, and to terrorists who could cause huge disruptions of oil shipments ... raise the price of oil ... and do great harm to our economy. ${ }^{\prime 75}$ The reference to hostile regimes in the U.S. debate on energy dependency has strong militant connotations, while the examples of climate change threats to energy security are more environmental or economic. Comparatively, Barry Barton states that in New Zealand there is not the same need to couch issues of oil dependency in terms of national security. ${ }^{76}$ Or, as Andrew Holland argues that the perception of oil dependence as a security risk is very different between Europe and the U.S.; Europeans have not felt the price spikes as keenly, due to their higher taxes and greater efficiency. ${ }^{77}$

Buzan et al.'s securitisation analysis in this respect, includes not only political and military sectoral understandings of security, but also environmental, economic and societal. The sectors provide a broader range of lenses though which different issues are viewed by actors, and bring to light exactly how New Zealand actors define security. ${ }^{78}$ While the sectors are viewed as analytical devices, Buzan et al. state that 'sectors exist not only in a theoretician's head but also in policy heads, where the concept of security itself is the integrating force,' and that 'actors think about economics, politics, and other areas but judge their main security problems across the board.'79 Analysing the lens through which an issue is politicised and securitised, or whether the same issue appears across a

\footnotetext{
${ }^{75}$ George W Bush, "State of the Union Address," The National Business Review, http://m.nbr.co.nz/article/state-union-address. p. 1

${ }^{76}$ Barry Barton, "Interview," (2011).

${ }^{77}$ Holland, "Climate Change and Energy Security: Overlapping Priorities." p. 6

78 Buzan, Waever, and Wilde, Security: A New Framework for Analysis. p. 168

${ }^{79}$ Ibid. p. 168
} 
number of sectors, can give an indication of how a security concept is debated or constructed. It can also explain how and why politicians in New Zealand may refer to energy security differently, through a subjective process of judging where the issue sits in their broader political agenda.

The success of securitising moves, relative to the sector analysis, can also indicate what existing narratives of security have the greatest political appeal. Why for instance, would Labour MP David Parker argue that energy security is paramount, and renewables have a 'vital role to play' in this. Or why would the Hon Gerry Brownlee, as energy spokesperson prior to the November 2008 election, argue that the National party would have an 'unrelenting focus on security of supply'? Securitisation Theory allows for consideration of these factors in the idea of resonating conditions. It is these conditions that make a securitising move successful, or unsuccessful, in convincing an audience that an issue should be addressed. They include consideration of how well an issue (presented using the language of threat) fits with existing perceptions of security, the status of the actor presenting the threat, and features of threat that can facilitate or impede securitisation. ${ }^{80}$ This includes contextual dynamics, developments and institutional contexts that enable 'securitising moves' to become successful. ${ }^{81}$

The resonating conditions can account for aspects of New Zealand that influence the way energy security risks are viewed and constructed. This can elaborate on why politicians or bureaucrats in New Zealand may couch energy security in certain ways, dependent on the existing discourse or policy approaches to security or energy. These could include physical characteristics of geological isolation; or idiosyncratic energy concerns such as the effects of drought on hydro damns, or political factors such as the free-market principles. Securitisation Theory also accounts for the international context that can equally

\footnotetext{
80 Ibid. p. 31

${ }^{81}$ McDonald, "Securitisation and the Construction of Security." p. 564
} 
influence the dynamics of energy security at the national level. New Zealand is largely self-sufficient in energy except for imported oil. This is unlike the European Union, who, for example, is reliant on the pipeline from Russia to provide its gas supply. ${ }^{82}$ The international context includes the imperatives of economic growth and consumption of fossil fuels in the Asia-Pacific region, climate change, high and volatile oil prices, uncertainty in the ability of energy markets to meet increasing demand, and indeed, the global economic recession.

Depending on resonating conditions securitising moves can result in a politicisation of an energy issue or a securitisation. First, according to Buzan et al. 'politicisation means to make an issue appear open, a matter of choice, something that is decided upon and that therefore entails responsibility [...]' This is in contrast to a securitisation which is to present an issue as urgent and existential, and 'so important that it should not be exposed to the normal haggling of politics, but should be dealt with decisively by top leaders prior to other issues.' 83 This is the case particularly on the international level, although not always on the domestic one. ${ }^{84}$ Second, securitisation can be viewed as a more extreme version of a politicisation. ${ }^{85}$ In this sense a politicisation can move 'up the scale' to a securitisation, given the right circumstances. ${ }^{86}$ Yet the relationship between a securitising move and its result is not always clear-cut. ${ }^{87}$ As Buzan et al. admit, it is less clear whether a securitising move 'points to specific emergency measures and a violation of normal politics or established rules.' 88

Shocking and immediate events in particular, can facilitate the clear securitisation of an issue. In terms of energy security this was the case in 1973/74 Arab Oil Crisis. Shock is a contributing factor in providing impetus for the construction of

\footnotetext{
82 Barton et al., Energy Security: Managing Risk in a Dynamic Legal Environment. p. 373

${ }^{83}$ Buzan, Waever, and Wilde, Security: A New Framework for Analysis. p. 29

${ }^{84}$ Ibid. p. 29

${ }^{85}$ Ibid. p. $23-24$

86 Ibid. p. 103 ,

${ }^{87}$ Gareth M Winrow, "Energy Security in the Broader Mediterranean," European Security 17, no. 1 (March 2008). p. 163

${ }^{88}$ Buzan, Waever, and Wilde, Security: A New Framework for Analysis. p. 178
} 
new security narratives. A current example is the 2001 attack on the World Trade Centre. Bryan Mabee, in his article Re-imagining the Borders of U.S. Security after 9/11: Securitisation, Risk, and the Creation of the Department of Homeland

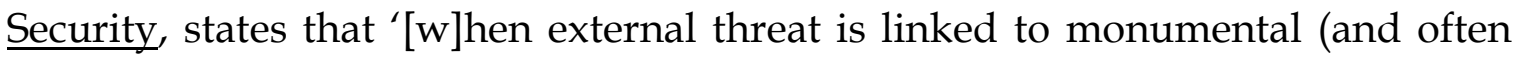
catastrophic) events, it can lead to historical openings for the rearticulating of security.' 89 The formation of the Homeland Security Department in the U.S. was a direct institutional response to the $9 / 11$ events and evident of a securitisation in response to terrorism. Disasters can also be embedded in the social psyche as a security issue, dealt with at the time through extraordinary measures and policy that prevail well after the disaster has passed. An event like Chernobyl for instance, can dictate subsequent action to make sure such an event would never occur again. 90

Politicisations however, are particularly relevant to the international debate on energy security. Determining the nature of energy security risks in regards to climate change, is difficult because the risks are long-term and not immediately apparent. It is also a subjective process, and leads to contestation in policyformation. When integrating climate risks with those of energy security, the debate naturally broadens and becomes more complex. The Intergovernmental Panel for Climate Change (IPCC) has provided the science behind the potential effects of climate change, such as the accelerated pace of natural disasters, however, how these are translated into policy are '[...] value judgements determined through socio-political processes, taking into account considerations such as development, equity, and sustainability, as well as uncertainties and risk.' ${ }^{91}$ The IEA World Energy Outlook 2010 states, '[t]he energy world is facing unprecedented uncertainty $[. . .]^{\prime 92}$ Thus the energy security and climate change

\footnotetext{
${ }^{89}$ Bryan Mabee, "Re-Imagining the Borders of Us Security after 9/11: Securitisation, Risk, and the Creation of the Department of Homeland Security," Globalizations 4, no. 3 (2007). p. 386

${ }^{90}$ Buzan, Waever, and Wilde, Security: A New Framework for Analysis. p. 74

${ }^{91}$ IPCC (2001) TAR, 'Synthesis report, summary for policymakers', available at http://www.ipcc.ch. In James Garvey, The Ethics of Climate Change: Right and wrong in a warming world, (London \& New York: Continuum International Publishing Group, 2008) p. 1 - 2 92 International Energy Agency, "World Energy Outlook 2010: Executive Summary," ed. OECD/IEA (Paris: International Energy Agency, 2010). p. 3
} 
nexus has sparked contentious debate on risk and a flurry of rhetoric. The Copenhagen School argues that politicisations are often present in a situation where there is uncertainty over the rules of the game and the nature of threat. ${ }^{93}$ Politicisations of energy security therefore tend to have a political purpose.

\section{The tactical appeal of security arguments}

When there is contentious debate on energy security and climate change risks, security arguments have tactical appeal. This is particularly the case for energy issues in which threats are long-term and not immediately apparent. The language of threat invokes a sense of urgency, of action, and of how it prioritises issues. ${ }^{94}$ This is why issues like climate change, or long-term energy security risks of oil dependency, may be politicised by politicians to inject a sense of urgency to address these issues. Oli Brown and Robert McLeman argue that 'Climate change was seen by security organisations as an issue lurking somewhere over the horizon, to be studied and monitored.' 95 Brown, of the International Institute for Sustainable Development (IISD) stated that raising climate change on the back of national security concerns is politically motivated to inject a greater sense of urgency to boost global efforts to reduce greenhouse gases. He argues that this is because the people who talk about security issues are prime ministers and presidents, and '[t]alking about climate change in security terms raises it to the realm of high politics. ${ }^{96}$ There has been faltering state action on climate change and robust debate over the nature and degree of threat it presents. Not to mention the difficult negotiations towards the who and how of reducing global greenhouse gas emissions. These environmental lobbies often result in

\footnotetext{
${ }_{93}$ Andrey Makarychev, "Energy Relations in Russia: Administration, Politics and Security," International Social Science Journal 57, no. Supplement s1 (May 2005). p. 107

${ }^{94}$ Buzan, Waever, and Wilde, Security: A New Framework for Analysis. p. 29

${ }_{95}$ Oli Brown, Anne Hammill, and Robert McLeman, "Climate Change as the 'New' Security Threat: Implications for Africa," International Affairs 83, no. 6 (November 2007). p. 1141 - 1142 ${ }^{96}$ Cited in Leonie Joubert, "Africa: Climate Change 'Is a Security Issue'," Global Information Network (31 August 2009). p. 1; See also Barry Buzan and Ole Waever, "Macrosecuritisation and Security Constellations: Reconsidering Scale in Securitisation Theory," Review of International Studies 35(2009). p. 254
} 
politicisations as, Buzan et al. state that 'In terms of politicising causes, much is happening, but most of the threats are too distant to lead to securitisation.' ${ }^{97}$ This raises the question of whether security arguments have been used in the energy debate in New Zealand, in terms of energy security or climate change.

Rhetorical politicisations of energy security, with tactical intentions, can have a variety of forms. An example is the politicisation of oil and gas by Venezuelan President Hugo Chavez prior to the Russian-Ukraine gas dispute of 2006. A substantial amount of literature on energy security concerns from the EU emerged that was set against the backdrop of the gas dispute. ${ }^{98}$ According to E. Harks, President Chavez warned of an oil export disruption to the U.S. while 'charming offensives towards China and the threat of euro-denominated oil exports.' 99 This situation coupled with the break-down of relations between Russia and Ukraine, skyrocketed the 'Eastern European energy scenario and problems associated with natural gas to the top of the political agenda of European governments.' 100 Thus the European Commission responded with an energy strategy: “Green Paper: A European Strategy for sustainable, competitive and secure energy." 101 Effectively, energy security was politicised and characterised by two competing energy policy responses. A. Makarychev argues that Russia politicised energy relations with concepts of 'energy sovereignty' and 'energy superpower' while the European Union did it by broadening the possibilities for normalising energy markets on the basis of the European economic model. ${ }^{102}$ Thus Securitisation Theory can also help understand how politicisations manifest in different energy policy responses.

\footnotetext{
${ }^{97}$ Buzan, Waever, and Wilde, Security: A New Framework for Analysis. p. 83, see also p. 91

98 Gawdat Bahgat, "Europe's Energy Security: Challenges and Opportunities," International Affairs 82, no. 5 (2006).; Raphael Sauter, "E.U. Energy Security from an Agenda-Setting Perspective Implications for E.U. Climate Change Policy?" (paper presented at the Energy Security in Europe: Proceedings from the Conference "Energy Security in Europe" Lund, Sweden, 2008).

${ }^{99}$ Enno Harks, "The Conundrum of Energy Security - Gas in Eastern and Western Europe," The International Spectator 3(2006). p. 48

100 Ibid. p. 48

101 Bahgat, "Europe's Energy Security: Challenges and Opportunities." p. 962

102 Makarychev, "Energy Relations in Russia: Administration, Politics and Security." p. 113
} 
The ways in which energy security is interpreted and rhetorically politicised can have real effects in politics as well as energy markets. First, how governments politicise energy security risks is particularly important to understand as it can have destabilising effects on energy relations. Energy markets are highly politicised arenas, especially when energy concerns are politicised as national security concerns. As Vlado Vivoda argues 'Energy security is a vital national security concern for all states and energy nationalism dominate the behaviour of nation-states in Asia.' ${ }^{103}$ For instance, an article entitled China or the United States: which threatens energy security?, addresses how China's role in the changing global energy market - where the price of oil is at records highs - has lead to debate centred on the 'China energy threat'. In particular the article states that ' $[t]$ he 'China energy threat' reflects the disputes between China and America over energy security, the majority of which are attributable to geopolitical clashes,' and that ' $[t]$ he politicisation of oil has already exerted considerable effect on the relationship between China and America over issues like Sudan $[\ldots]^{\prime 104}$ Second, governments have the difficult role of managing risks to energy security that can stem from international or domestic energy markets. Thus a politicisation of energy security can also highlight imperfections in these markets. Harris and Naughten state, in '[...] in economic terms, security problems imply what economists refer to as market failures or market imperfections.' ${ }^{\prime 105}$ These market imperfections can include new risks that global energy resources will be constrained by rising demand and low supply margins, or the externalities of the process of consuming these resources on a warming climate. Thus politicisations of energy security risks from the energy market especially by governments, implies that an energy policy response is needed.

In the United States, tactical politicisations of energy security have manifested in institutional restructuring to address new risks in energy policy. First, energy

\footnotetext{
103 Vlado Vivoda, "Evaluating Energy Security in the Asia-Pacific Region: A Novel Methodological Approach," Energy Policy 38(2010). p. 5262

${ }^{104}$ Liu Xuejun Wu Lei, "China or the United States: Which Threatens Energy Security?," OPEC review 31, no. 3 (September 2007).p. 224

${ }^{105}$ Harris and Naughten, "Economic Dimensions of Energy Security in the Asia-Pacific." p. 184
} 
security can be politicised within domestic politics, and made part of the institutional framework for dealing with energy concerns. The U.S. Secretary of State Hillary Clinton created the International Energy Affairs at the State Department, to demonstrate the importance of energy security to U.S. Foreign Policy. ${ }^{106}$ To what extent has a similar move been made in New Zealand? Was David Parker's appointment to both Minister of Energy and Minister Responsible for Climate Change Issues in 2005 a strategic move to politicise energy security? President Barack Obama's sentiment reinforces the institutional move made by Hillary Clinton, most recently in regards to how unrest in the Middle-East (with implicit reference to Libya, as well as the tsunami and nuclear disaster in Japan) connects to 'the cost and security of our energy.'107 And in particular, how the situation in the Middle East implicates our energy security.'108 Has New Zealand couched these new energy concerns in terms of energy security? If not, why not? Securitisation Theory provides the basis to find answers to these questions by first, pinpointing where security arguments have been used. Second, Securitisation Theory can also highlight different features of a politicisation of energy security (other than just a security argument), as seen in the example of Clinton's creation of the International Energy Affairs.

Securitisation Theory can show the tactical features of an actor's presentation of energy security risks in energy politics. First, Securitisation Theory highlights the different lenses through which an energy risk can be framed. Second, the theory examines the success of the politicisation in relation to existing risk perceptions and institutions. Thus where politicisations of energy security are tactical moves can be highlighted: to support new energy policy initiatives to address climate change by framing energy security risks in both economic, military and environmental terms. The U.S. for instance, may feel primarily threatened by

\footnotetext{
106 Jenni Wiener, "Search for Oil Alternatives, Based on National Security, Goal of Clean Energy," VOANews.com, http://www.voanews.com/english/news/economy-and-business/Goals-ofClean-Energy-National-Security-Propel-Search-do-Alternatives-to-Oil-99563139.html. ${ }_{107}$ Barack Obama, "Remarks by the President on America's Energy Security," The White House, http://www.whitehouse.gov/the-press-office/2011/03/30/remarks-president-americas-energysecurity. 108 Ibid.
} 
military matters and therefore define security in military terms, ${ }^{109}$ which affects how different issues that arise are assimilated into the country's politics. President Obama used similar language, in relation to hostile regimes, and terrorism - evidently a military concern - but added the effects of climate change (an environmental issue) in the same way. He highlighted the dire need for the U.S. to reduce its oil dependency and gave it urgency by stating that 'America will not be held hostage to dwindling resources, hostile regimes and a warming planet $[\ldots]^{\prime} 110$ The issue of oil dependency and its associated threats, were presented by President Barack Obama not only with militant connotations but also with vast environmental and societal consequences. Thus Securitisation Theory can not only show where politicisations of risks are tactical, but also highlight features that influence how issues are presented in politics.

Whether New Zealand's political leaders have politicised energy security risks can be determined using Securitisation Theory. Analysis of this kind can also reveal features of New Zealand's institutional structure for dealing with energy concerns. Furthermore, it can reveal the extent to which energy security has been politicised in attempt to change existing perceptions or push through new policy. Essentially President Obama's politicisation of threats associated to oil dependency is what Holger Stritzel terms an 'act of translation,' where a new threat or issue is worked into the existing discourse. The better the resonance of this new threat with the old security framework, and the better the positional power of the actor, Stritzel argues, 'the easier it is for them to establish their preferred individual text as a dominant narrative for a larger collective.' 111 President Obama appeals directly to military narratives that strike a particular chord, then assimilates this more powerful narrative of terrorism with a less powerful one: the need to reduce oil dependency. This is also associated to the need to reduce greenhouse gas emissions and address climate change. Whether

\footnotetext{
109 Buzan, Waever, and Wilde, Security: A New Framework for Analysis. p. 168

110 Barack Obama, "Obama Orders Push to Cleaner, More Efficient Cars," 3news.co.nz, http://www.3news.co.nz/Obama-orders-push-to-cleaner-more-efficientcars/tabid/728/articleID/88601/Default.aspx.

111 Stritzel, "Towards a Theory of Securitisation: Copenhagen and Beyond." p. 370
} 
President Obama is successful in convincing others that all of these threats are urgent enough to address oil dependency equally suggests something of the nature of security in the U.S.: namely that the transition of the U.S. economy to clean energy, and low-carbon, faces strong debate and obstacles. ${ }^{112}$ Buzan et al. state for instance, that one of the difficulties of securitising environmental issues is that these new threats 'find themselves operating in a political context dominated by security institutions designed for other types of threats.' 113 Institutional arrangements and resonating conditions have their role to play, and therefore can impede or facilitate the securitisation of new threats. In sum, New Zealand's institutional structures that address energy security and perceptions of risk can be more thoroughly understood using Securitisation Theory.

\section{Conclusion}

Securitisation Theory can examine the extent to which energy security is political in New Zealand. In other words, Securitisation Theory can examine how and why energy security has been framed in politics or as something to be addressed by government. First, Securitisation Theory identifies how an issue is presented by an actor in order to encourage action to address the issue within or above politics. The framing of energy security concerns can be unpacked using the idea that issues can be viewed through otherwise conflicting lenses. Environmental and economic lenses will be particularly relevant to the analysis of energy security. Second, Securitisation Theory unpacks the resonating conditions and pressures that influence how energy security risks are politicised. This can also help evaluate the reasons for the success of these risks being addressed in debate and policy. Analysis will also reveal features of the New Zealand's institutional structures for addressing energy security concerns, as well as perceptions of risk in the domestic policy environment that are shaping energy policy. This is

\footnotetext{
112See Suzanne Goldenberg, "Republicans Attack Obama's Environmental Protection from All Sides," guardian.co.uk, http://www.guardian.co.uk/world/2011/mar/04/republicans-attackobamas-environmental-protection?INTCMP=SRCH.;

${ }^{113}$ Buzan, Waever, and Wilde, Security: A New Framework for Analysis. p. 29
} 
important to understand because as much as energy security can be a technical and administrative problem for actors in the energy market, it can also be a highly political and contested one in domestic and international politics. New Zealand, like other governments, face complex questions for policy in regards to energy, as energy is at the centre of both climate change and economic growth. Fundamentals of the global energy market are changing particularly in regards to oil which is in greater demand and more highly priced than previous years. The extent to which new threats to energy security are also presented in New Zealand energy politics will reveal much about its approach to the complexity of energy issues.

Throughout the remainder of the discussion, this thesis will apply the Copenhagen School's framework of analysis to key energy policy documents, reports, discussions and, speeches and media releases by relevant politicians and bureaucrats, news articles in the New Zealand media, as well as broader political dialogue on energy policy between government and key stakeholders. Energy security has been politicised in a variety of ways. In some instances, particularly the United States, politicisation has a role in the political debate to deal with climate change. Specifically, to what extent may this have played out in New Zealand energy politics? Governments face both international and domestic pressures when it comes to energy politics, and energy security. For instance on the domestic front, John Deutch argues that ' $\mathrm{t}$ ] he public understandably wants cheap and dependable energy that permits an improved lifestyle and neither harms the environment nor depends on foreign sources. Simultaneously satisfying all these conditions is difficult, if not impossible $[\ldots]^{\prime 114}$ Then on the international front Anthony Froggatt and Michael A. Levi state that concerns for climate change and energy security 'are leading to greater government intervention in the energy sector than has existed since the start of energy market

\footnotetext{
${ }^{114}$ John Deutch, "Prority Energy Security Issues," in Energy Security and Climate Change: A Report to the Trilateral Commission, ed. John Deutch; Anne Lauvergeon; Widhyawan Prawiraatmadja (Washington, Paris, Tokyo: The Trilateral Commission, 2007). p. 3
} 
liberalisation several decades ago.' ${ }^{115}$ In this respect, the way governments interpret and present energy security in their domestic and international affairs can shed light on the way they intend to manage these different pressures, particularly risks and insecurities that stem from the energy market or the challenges of climate change. New Zealand is no exception to these challenges.

${ }^{115}$ Froggatt and Levi, "Climate and Energy Security Policies and Measures: Synergies and Conflicts." p. 1129 


\section{Chapter Three}

\section{The Clark Labour Government, Energy Security and Climate Change}

The Clark Labour Government used a strategy of politicisation to bring energy security issues onto the political agenda. This helped to forge an integrated, whole-of-government approach to climate change policy. This chapter will use Securitisation Theory to explain how energy security was politicised and the role it played in the policy-making process. It will argue that the Clark Government used particular energy security rhetoric to legitimise its robust policy response to climate change. First, energy security was identified as a challenge alongside climate change that required strong government leadership and policy action. It was used as an umbrella term for risks to New Zealand's energy system. In particular, new risks from the international and domestic energy markets were given emphasis. These energy security risks were presented through both environmental and economic lenses and, therefore, demonstrated the Government's efforts to synthesise energy concerns in policy response. The Clark Government politicised energy security in this way consistently between relevant government departments dealing with climate change and energy policy. Thus a strategy of politicisation is clear: energy security risks were identified that required a policy-response. This response would be through government leadership in the energy sector to develop robust climate change policy.

The chapter is in four parts. The first section analyses the use of energy security in the major document on energy policy in New Zealand: the New Zealand Energy Strategy 2007. The second section will extend analysis to other policy documents, speeches and media releases during the Labour Government. The way government departments, including the Ministry of Economic Development and the Ministry for the Environment, refer to energy security will be critically 
examined. A security argument was used to highlight the long-term risks of energy security in support of strong climate change policy. The third section will show the extent to which energy security risks were politicised, drawing also on the documents and mandates of the Ministry of Transport and the Ministry of Foreign Affairs and Trade. The fourth section shows how energy security was integral to the Labour Government's international climate change agenda. Energy security was politicised as a tactical move by Labour to support its other objective: to address international climate change in domestic policy through the promotion of sustainability and economic transformation.

\section{The New Zealand Energy Strategy to 2050: powering our future}

Energy security in the Ministry of Economic Development (MED) under the Labour Government was politicised alongside climate change as a key challenge for energy policy. This was articulated in the New Zealand Energy Strategy (NZES), released in October 2007.116 The MED under the Labour Government had a clear strategic objective to respond to climate change. The Minister of Energy, David Parker, stated in the Foreword of the NZES 2007 that '[t]he New Zealand Energy Strategy sets the strategic direction for the energy sector to contribute to New Zealand's future prosperity and sustainability.' 117 The Government's primary concerns were to promote economic transformation by formulating New Zealand's response to climate change. ${ }^{118}$ According to the NZES 2007 the quest for sustainability 'has taken on a new urgency because of the scale of the environmental challenges the world faces.'119 First, the NZES of 2007 would respond to this urgency on the basis of the Clark Government's objectives: 'provide clear direction on the future of New Zealand's energy

\footnotetext{
${ }^{116}$ Ministry of Economic Development, "New Zealand Energy Strategy to 2050: Powering Our Future." p. 12

117 Ibid. p. 5

118 Ibid. p. 5

119 Ibid. p. 5
} 
system,'120 defined by the aspiration for 'New Zealand to be carbon neutral over time.'121 Two key aspects of this framework affect the concept of energy security: the apparent link to the urgent issue of climate change and the concern for the future of New Zealand's energy system in relation to the goal of reducing greenhouse gas emissions.

During the NZES 2007 the Clark Government politicised energy security as a challenge in tandem with climate change, with a clear ambition to provide leadership in the energy sector in order to address these challenges. To restate, if an issue is politicised it is part of public policy and requires government decision, resources or governance. ${ }^{122}$ Energy security and climate change are at the core of the strategy and under this umbrella '[t]he New Zealand Energy Strategy specifically responds to the challenges of providing enough energy to meet the needs of a growing economy, maintaining security of supply and reducing greenhouse gas emissions.' ${ }^{123}$ The Minister for Energy David Parker stated that, 'the strategy will ensure the right conditions for capital investment in coming years and provide leadership on energy security and climate change.'124 The importance placed on the Government's leadership on both challenges suggests indeed that governance, resources and strong decision-making are needed to deal with these challenges.

\section{Risk perceptions and climate change policy}

The NZES 2007 applied a security argument to its climate change policy by highlighting energy security risks. First, energy security risks in the international energy market were discussed. In the section 2.1 Energy Security, it states that 'the pressure on global energy resources is expected to increase strongly [...] oil

\footnotetext{
120 Ibid. p. 17

${ }^{121}$ Ibid. p. 9

122 Buzan, Waever, and Wilde, Security: A New Framework for Analysis. p. 23

${ }^{123}$ Ministry of Economic Development, "New Zealand Energy Strategy to 2050: Powering Our

Future." p. 5

124 Ibid. p. 5
} 
markets may come under pressure due to supply constraints within the next five years.' ${ }^{25}$ Second, it argues that these consumption patterns mean that, 'within a decade, the capacity to increase oil production will be concentrated to just a few predominantly OPEC countries.' Following, that as the IEA has reported, 'the ability and willingness of major oil and gas producers to step up investment in order to meet rising global demand are particularly uncertain.'126

This argument strikes a chord with the historic fear of oil supply disruptions in the 1973/74 Arab Oil Crisis, when the Organisation of the Petroleum Exporting Countries (OPEC) reduced oil supplies to particular countries through embargo action. ${ }^{127}$ Professor Ralph Sims suggests these historic energy security fears remain in politicians' minds. ${ }^{128}$ In the NZES 2007 these fears broaden to new risks in the uncertainty of the market to maintain supply to meet the international rising demand for energy. New Zealand's reliance on this market is exposed, insofar as the country relies on 'imported oil for around half of [its] energy needs, and must be prepared to respond to supply disruptions $[\ldots]^{\prime 129}$ and that the Government has buffered against this risk by increasing oil reserves to meet its IEA obligations. Invoking uncertainty in this market brings to mind not only the fears of a repeat of political exploitation of oil by OPEC, but also questions of security of supply in the efficient but insecure, economic dependence of a nation on outside sources of energy supply. ${ }^{130}$

In the NZES 2007, these risks of the international market support the argument for a domestic policy response to climate change. The NZES 2007 argues that New Zealand, the referent object, will be affected by an increasing import bill

\footnotetext{
125 Ibid. p. 13

126 Ibid. p. 13

127 MacNaughton, "Cooperating on Energy Policy: The Work of the International Energy Agency." p. 280

128 Ralph Sims, "Interview," (2011).

${ }^{129}$ Ministry of Economic Development, "New Zealand Energy Strategy to 2050: Powering Our Future." p. 12

130 Barry Buzan, Ole Waever, and Jaap de Wilde, "The Economic Sector," in Security: A New

Framework for Analysis (London: Lynne Rienner Publishers, 1998). p. 98
} 
relative to increasing oil prices which is all the more reason to lessen our dependence on imported oil. ${ }^{\prime 131}$ Furthermore in section 4.6.2 Transport, it states that '[i]t is in New Zealand's wider interests to reduce our transport emissions and our dependence on imported oil.' ${ }^{132}$ Again this is essentially a security argument, as Harris and Naughten state, '[...] in economic terms, security problems imply what economists refer to as market failures or market imperfections.' ${ }^{133}$ New Zealand can simultaneously hedge against oil price uncertainty and disruptions (market imperfections) and address climate change through emissions reductions in the transportation sector. ${ }^{134}$ Energy security embodies a heightened awareness of new risks and uncertainty in the energy market, and in this respect is presented in a way that supports the Clark Government's political agenda to form more robust climate change policy.

This emphasis on New Zealand's exposure to international energy security risks is integrated with a presentation of risks in the domestic market. Again, by highlighting these risks the NZES 2007 is implying that governance of the energy sector is required in order to address them. The NZES 2007 proposed energy security measures include first, that this uncertainty can be addressed in an effective policy response. ${ }^{135}$ The section on Energy Security highlights how gas supplies can be 'interrupted by international events', and that simply using more gas without developing oil reserves is not enough, as prices will increase in the gas and electricity sector. ${ }^{136}$ In the section entitled Measures to Ensure Energy Security, it states that in terms of non-renewable resources an energy security measure is '[c]larifying the long-term role of gas (including LPG), oil and coal and other alternative energy sources in New Zealand's energy mix,'137 and

\footnotetext{
${ }^{131}$ Ministry of Economic Development, "New Zealand Energy Strategy to 2050: Powering Our Future." p. 13

132 Ibid. p. 23

${ }^{133}$ Harris and Naughten, "Economic Dimensions of Energy Security in the Asia-Pacific." p. 184

134 Ministry of Economic Development, "New Zealand Energy Strategy to 2050: Powering Our Future." p. 17 In regards to the introduction of electric cars, New Zealand will be 'more resilient to international oil price uncertainty and risks of supply disruptions.'

135 Ibid. p. 13

136 Ibid. p. 12

137 Ibid. p. 19
} 
'[i]ncreasing energy efficiency and resonating demand-side response.' 138 The use of non-renewable resources such as oil and coal, contribute to climate change. Clarifying their role and managing their consumption through energy efficiency are examples of climate change policy. Other measures include regulations in the market, the most important being '[a]n ongoing commitment to competitive markets and focused regulation to deliver the objectives of the NZES.' ${ }^{\prime 39}$ These examples all equate to emphasising the risks and threats to energy supply that in turn can be addressed through government initiatives in climate change policy.

Energy security embodies risks in the domestic and international energy market, but in particular these are long-term risks. As Chapter Two highlights, security arguments have tactical appeal in the energy security and climate change debate when threats associated to both are not immediately apparent. In the NZES 2007, clarifying the role of different resources in the present hedges against perceived long-term risks of an uncertain future in the energy market. The NZES 2007 in this respect, the long-term scope of energy security policy with the long-term scope of climate change policy. This is evident in the policy focus on renewable resources. In section 4.6.1 Electricity, the NZES 2007 states that it is in New Zealand's longer-term economic and environmental interests to meet increases in demand through an economic mix of renewable energy sources that will meet our security objectives.' ${ }^{140}$ Here, economic and environmental concerns are synthesised with national interest and energy security, ultimately to argue the benefits of relying on renewable energy for future energy sources. These objectives are centred in the development of renewable resources and target of 90 percent renewable electricity generation by $2050 .{ }^{141}$

The Ministry for the Environment (MfE) presented the same line of argument for renewable energy policy: highlighting the long-term risks to energy security if

\footnotetext{
${ }^{138}$ Ibid. p. 19

139 Ibid. p. 19

140 Ibid. p. 22

${ }^{141}$ Ibid. p. 17
} 
the Government does not provide clear leadership on climate change policy. The Clark Government proposed a National Policy Statement in support of the NZES 2007. The NPS aimed to encourage all new developments in electricity generation to be from renewable resources only. ${ }^{142}$ This was to be implemented through an amendment to the Resource Management Act. The MfE argued that the NPS would lead to greater certainty in the market for renewable energy, and that this would increase security and resilience of electricity supply. ${ }^{143}$ Or in other words, renewable energy would increase New Zealand's energy security. Second, the MfE highlighted risks to energy security if the government did not take this legislative measure. This again, is bolstered by the argument that there is market uncertainty due to a lack of government leadership. In a report on the reasons for implementing the NPS, the MfE stated that,

[..] the proposed NPS identified that market uncertainty created by lack of clear government direction on the benefits of renewable electricity generation introduces a risk that generators will be unable to develop sufficient capacity to meet the government's renewable electricity targets as expressed in the New Zealand energy strategy. ${ }^{144}$

The Clark Government thus politicised long-term energy security risks in order to bring the future of New Zealand's energy sector to the focus of policy. Here, energy security risks are not immediate or a case of survival, but they do have tactical appeal to support climate change initiatives. The presentation of energy security was clearly in support of the NPS and the NZES 2007. Energy security embodied future risks and uncertainties of the energy market. These risks were considered important enough to deem a strong policy response in the present by

\footnotetext{
142 Ministry for the Environment, "Archived Publication: Renewable Energy Solutions Combat Climate Change," mfe.govt.nz, http://www.mfe.govt.nz/publications/about/environz/environz-jul07/page8.html. 143 _ - - , "Proposed National Policy Statement for Renewable Electricity Generation," mfe.govt.nz, http://www.mfe.govt.nz/publications/rma/nps-for-renewable-electricitygeneration-ris/html/ page1.html. 144 Ibid.
} 
the Clark Government. Energy security in this respect, is a politicised issue that supports the need for governance of the energy sector, not just for energy security's sake, but also for New Zealand's policy response to climate change.

\section{The politicisation of energy security}

The extent of this politicisation was evident in the consistency of presentation and perceptions of energy security between relevant government departments and agencies. This also suggests that the Clark Government's energy security and climate change agenda were taking on a strong institutional form. This is evident in the New Zealand Transport Strategy released in 2008 prior to the election of the Key National Government. The New Zealand Transport Agency is responsible for helping 'New Zealanders travel reliably and safely and to grow the country's economy by investing in moving people and freight,' as well as delivering national transport networks and support local networks, and making public transport and freight networks more effective. ${ }^{145}$ Prior to the 2008 election the Ministry of Transport outlined a strategic approach to research on the basis that 'New Zealand's transport sector has an important part to play in contributing to the government's goal of economic transformation and energy conservation for New Zealand [...]'146 This drew on key challenges identified by the NZES 2007, energy security and climate change, and emphasised even more so the threats oil dependency posed to the New Zealand economy. The presentation of these concerns in strategic documents also gives a clear indication that the issues are deemed to be important enough to be integrated into the strategic focus of the Ministry of Transport.

The language of risk and vulnerability was used in relation to New Zealand's dependency on the international energy market. The NZTS states that 'supplies

\footnotetext{
${ }^{145}$ New Zealand Transport Agency, "About Us," nzta.govt.nz, http://www.nzta.govt.nz/about/index.html.

146 - - - , "NZ Transport Agency's Approach to Research 2009-12," (Wellington October 2008). p. 8
} 
of conventional (cheap) oil are finite, and global demand is growing due to rapidly increasing consumption in developing countries like China and India.'147 This is coupled with recognition of the interconnected nature of the New Zealand economy and international markets, insofar as New Zealand's economic future as a trading nation is closely linked to the international economy. ${ }^{148}$ Hence New Zealand is highly dependent on fossil fuels for transport, and that the '[...] nation is vulnerable to potential fuel supply disruptions and future cost increases. ${ }^{\prime 49}$ The referent object here is the 'nation,' as well as the economy, where it states that ' $[\mathrm{i}] \mathrm{f}$ oil shortages or high costs occur before alternatives can be found, they would have an adverse impact on the New Zealand economy.'150 The use of the nation compared to the economy implies not only macro-level success of the country but also the security of communities and individuals. This could well be the case considering that the NZTS also highlights the relationship between high oil costs and increasing price of commodities, the cost of public transport, implications for tourism, business, and price of goods that need to be transported as well as the everyday New Zealander 'getting around.' It also states that '[t]hose on low incomes are particularly vulnerable.' 151 The NZTS presents oil dependency through an economic lens, specifically in regards to the threat of the rising price of oil to the economy that is linked also to individuals' standard of living.

The NZTS also presented these economic risks of oil dependency through an environmental lens of concern for climate change. First, the NZTS argued that economic performance and growth will likely result in higher transport demand in the future, and 'Such growth in demand will place significant burdens on the transport network and could harm economic competitiveness as a result of congestion [which] may adversely affect the social and environmental wellbeing

\footnotetext{
${ }^{147}$ Ministry of Transport, "The New Zealand Transport Strategy," ed. Ministry of Transport (newzealand.govt.nz, 2008).p. 25

148 Ibid. p. 24

149 Ibid. p. 26. My emphasis.

150 Ibid. p.26

${ }^{151}$ New Zealand Transport Agency, "Nz Transport Agency's Approach to Research 2009-12." p. 26
} 
of New Zealanders [...] $]^{\prime 152}$ This policy is driven by the need to reduce emissions from transport to meet New Zealand's climate change obligations. ${ }^{153}$ Consequently, these risks can be mitigated through New Zealand's 'potential to generate renewable electricity and, in future, to produce sustainable bio-fuels.' ${ }^{154}$ Energy security is clearly used in the argument to transition to other sources of fuel that can align with climate change concerns, and benefit energy security. Or that the challenge for New Zealand is to decrease energy use in the transport sector, while moving to sources of energy that are not based on fossil fuels, and are less vulnerable to changing international prices and availability.' ${ }^{155}$ Again this is in tune to the NZES 2007 presentation of risks. The NZTS uses the same language to emphasise the need to address these challenges in a way that can also synthesise with climate change concerns.

The synthesis of energy security risks with climate change policy was also evident in the Ministry for the Environment. MfE is the lead department on international climate change and domestic environmental issues and governance. The Ministry states that it 'advises the Government on all matters related to the environment and is one of its major advisers on the sustainable development of New Zealand,' furthermore that their 'advice includes both international and domestic matters related to the environment and climate change' as well as advice on effective environmental governance. ${ }^{156}$ Under the Labour-led Government the MfE argued that domestic energy security is improved through reducing oil imports and developing domestic renewable resources, both linked also to reducing emissions to 'improve our environment.' 157 Energy security risks

\footnotetext{
152 Ministry of Transport, "The New Zealand Transport Strategy." p. 24 - 25

153 Ibid. p. 27

154 Ibid. p. 26

155 Ibid. p. 25

156 Ministry for the Environment, "Statement of Intent 2010 - 2013,," (Wellington: Ministry for the Environment,, May 2010). p. 4

157 - - - , "Archived Publication: Why a New Zealand Emissions Trading Scheme?," (Wellington: Ministry for the Environment, September 2007). p. 4 See also, _- - - "Archived Publication: Renewable Energy Solutions Combat Climate Change."
} 
were clearly included in the MfE's ambit, and framed in a way to support climate change initiatives in energy policy.

Increased energy security was presented as a benefit of the Government's implementation of a number of policies and measures to reduce emissions and prepare for climate change, among them, improving the fuel efficiency of vehicles, increasing the standards for insulation in buildings, and encouraging renewable energy.' 158 The concept of energy security was characterised by a common recognition, by the Ministry for the Environment, the Ministry of Economic Development and the New Zealand Transport Agency, of the risk of oil import dependency and the benefit of the renewable energy focus on increasing domestic supply. Domestic energy security was again presented as a response to international uncertainties in the oil market and a benefit from climate change policy. The concept therefore, had a strong international dimension, which was politicised and integrated into domestic strategy.

\section{Energy security and New Zealand's international climate change agenda}

The Clark Government's political agenda on climate change policy also had a strong international dimension, which informed how it perceived energy security's strategic role in promoting sustainable economic development both at home and abroad. The Clark Government decided that it wanted to position New Zealand at the forefront of climate change policy. According to the Ministry for the Environment's Statement of Intent 2007 - 2010 (SOI 2007 - 2010), New Zealand's policy around sustainability would inform the country's interactions at the international level, among them on energy and climate change, and was 'designed to position New Zealand as an innovative and interlinked nation in a

${ }^{158}$ Ministry for the Environment, "Archived Publication: Why a New Zealand Emissions Trading Scheme?." p. 4 
future (low carbon) world.'159 Ministry of Foreign Affairs and Trade's (MFAT) Statements of Intent under the Labour Government clearly outlined environmental sustainability as a key priority for New Zealand. For instance, MFAT's SOI 2007 - 2010 refers to the way in which climate change brings about concerns for sustainable resource and development strategies, the environment and energy security. ${ }^{160}$

MFAT also politicised energy security as an international issue integrated with other concerns for economic growth and climate change. First, the SOI 2007-2010 released under Labour refers to energy security in tandem with competition for natural resources, where '[t]he integration of worldwide markets for labour, goods, services, capital, and technology is quickening, with increasing competition for natural resources and energy security.'161 Energy security here is related to the guarantee of access to resources, and more broadly, to the guarantee of supply to meet demand. This is not surprising, because at the time international literature tended to focus on two concerns that were becoming increasingly acute in the Asia-Pacific, namely, the increasing oil import dependency from fewer supplier countries, mostly concentrated in the MiddleEast, and the region's economic dependency on petroleum. ${ }^{162}$

The SOI 2007-2010 also politicised energy security as both an economic and environmental concern, and linked it to climate change. It states that ' $[t]$ he issue of climate change brings together many concerns about the environment, energy security, and sustainable resource and development strategies,' and energy security naturally is a key feature because 'responses to climate change are likely

\footnotetext{
159 - - - , "Statement of Intent 2007 - 2010," (Wellington: Ministry for the Environment,, May 2007). p. 50

160 Ministry of Foreign Affairs and Trade, "Statement of Intent 2007-2010 Incorporating the Forecast Financial Statements for 2007/08." p. 15

${ }^{161}$ Ibid. p. 14

162 Lynch, ed. Energy Security: The Foreign Policy Implications. p. 11 - 13; Vivoda, "Evaluating Energy Security in the Asia-Pacific Region: A Novel Methodological Approach." p. 5259;Wesley, Energy Security in Asia. P. 2 -3; Kang Wu et al., "Strategic Framework for Energy Security in Apec," ed. National Center for APEC (Honolulu Hawaii: East West Center, 2008). p. 1
} 
to sit within a broader context of promoting sustainable practices across economies, including [...] energy [...] $]^{\prime 163}$ In turn, strategically, the focus for New Zealand's engagement in the international environment agenda was to promote New Zealand's domestic values and interests, where '[a]n increasingly important dimension in our engagement is around issues of environmental sustainability.' 164 Energy security is recognised as a key feature on the operating landscape, and concerns for energy security were presented as integral with dialogue on climate change.

For MFAT, promoting the energy security and climate change agenda was evident in dialogue on economic development in the Pacific region. New Zealand's involvement with the United States in the International Partnership for Energy Development in Island Nations (EDIN) aimed to '[...] increase energy security in island nations by promoting clean energy technologies.' 165 In 2006, at the 37th Meeting of the Pacific Islands Forum (which MFAT participated in), it was reported that 'Leaders recognised the detrimental impact on people and countries in the region of increased oil prices particularly in small island economies,' and moreover that '[t]hey affirmed the importance of assured longterm energy security to the future prosperity of the region.' ${ }^{166}$ Not only are price concerns being articulated here, but clearly the long-term features of energy security were also negotiated. Finally, according to the report, the leaders 'welcomed proposals to explore the possibilities for bulk petroleum purchasing and for exploitation of renewable energy resources.' 167

The same approach was taken on at the Asia-Pacific level as well. For instance, in the East Asia Summit (EAS) New Zealand made progress in contributing to 'new streams of work on environment and education, and on-going work on energy

\footnotetext{
163 Ministry of Foreign Affairs and Trade, "Statement of Intent 2007-2010 Incorporating the Forecast Financial Statements for 2007/08." p. 15 164 Ibid. p. 53

165 _ - - , "Annual Report 2007/08," (mfat.govt.nz, For the year ended 30 June 2008). p. 14

166 _ - - , "37th Meeting of the Pacific Islands Forum" (paper presented at the Forum

Communique, Nadi, Fiji, 24-25 October 2006). p. 1

167 Ibid. p. 1
} 
security and financial cooperation [...] $]^{\prime} 168$ This is also referenced by MFAT today, where mention of energy security in EAS is seen as another 'avenue to work with our neighbours. ${ }^{169}$ Another regional body mentioned is APEC, in which progress was described as 'secur[ing] Leader's Declaration on Climate Change and Energy Security.' ${ }^{170}$ Engaging with energy security and promoting on-going work for it to be achieved in light of environmental and climate change considerations, was evidently regarded as a positive in New Zealand foreign policy.

The foreign policy approach synthesises with the approach to energy security and climate change in the NZES 2007. This is evidence of how in many ways, the domestic and foreign policy agendas were in step. Interestingly the international concern for energy security in the NZES 2007, particularly the uncertainty in the oil market, played out in foreign policy through a military lens of security. At the time of the Clark Government, New Zealand was engaged in the conflict in Afghanistan; and, more broadly, the War on Terror was still fresh in the minds of key players in the international community. MFAT's regard for the region shows reference to key characteristics of energy security issues of secure supply at affordable prices, as '[New Zealand shares] with many countries an interest in secure energy supplies at affordable prices. These interests give New Zealanders a direct stake in the stability of this turbulent region. ${ }^{171}$ Identified as an 'Area of Concentration and Intervention', the SOI 2007 highlighted that support for stabilisation, reconstruction and reconciliation effort in the Middle East was consistent with 'New Zealand security interests and values.' Furthermore, tensions in this region involve major international political and economic challenges that shape the 'global environment in which New Zealand operates.' ${ }^{172}$ In sum, international energy security issues were not presented in

\footnotetext{
168 - - - , "Annual Report 2007/08." p. 14

169 - - -, "Our Future with Asia," mfat.govt.co.nz, http://www.mfat.govt.nz/Media-andpublications/Publications/Asia-White-Paper/0-asia-strategy.php.

170 - - - , "Annual Report 2007/08." p. 40

$171 \ldots-$, , "Statement of Intent 2007-2010 Incorporating the Forecast Financial Statements for 2007/08." p. 35

172 Ibid. p. 35
} 
isolation to New Zealand's domestic interests, rather, they were clearly integrated with domestic policy.

\section{Conclusion}

Energy security risks were coherently presented across government departments and agencies under the Clark Government. A strategy of politicisation was used to bring particular energy security risks onto the political agenda, and argue that these required clear leadership of the Government in the energy sector. The domestic and international climate change agenda of the Clark Government shaped how energy security risks were presented and responded to in energy policy. As a politicised issue with climate change, energy security embodied long-term risks and uncertainty associated to the domestic and international energy markets. Additionally, it was used to demonstrate that these market externalities needed to be addressed. Energy security was also presented as a benefit of policy initiatives to address climate change, such as renewable energy policy and energy efficiency. The politicisation of energy security spread across government departments and agencies. This demonstrated the extent to which the Clark Government sought to institutionalise common perceptions of energy security risks. Second, these risks were not only framed in economic terms but also environmental ones that related the concept of energy security to climate change. Furthermore, the domestic approach to energy security and climate change was also integral to the Government's foreign policy agenda to position New Zealand as an innovative nation in climate change policy. The task of the next chapter is to analyse how energy security is referred to under New Zealand's present government. John Key's National Government's goal is economic growth, and the Ministry of Economic Development has identified the promotion of energy security as a way to help achieve this goal. The extent to which this agenda has shaped the presentation of energy security, and how different risks are prioritised in support of the Government's interests, will be specifically highlighted for further analysis. 


\section{Chapter Four}

\section{The Key National Government, Energy Security and Economic Growth}

The Key National Government marks a dramatic shift in how energy security is presented in energy policy since the Clark Government. The Key Government adopted the energy security label, but uses a strategy of politicisation to prioritise energy security policy measures that will contribute to economic growth. This chapter will use the Copenhagen School Theory of Securitisation to outline the key features of this move. First, energy security no longer embodies domestic and international risks. Instead, it embodies a heightened concern for security of supply. Second, it is presented as something that will contribute to economic prosperity and growth. Third, energy security is no longer included in the discourse of foreign policy documents and government departments, other than the Ministry of Economic Development's current energy strategy. These are the key features of the Key Government's distinct rhetorical politicisation of energy security to legitimise the prioritisation of petroleum and mineral resource exploitation: policy measures that will contribute to New Zealand's economic prosperity as well as global energy security. This is in distinct comparison to the Clark Government's approach to energy security that was shaped by the prioritisation of renewable resources and robust climate change policy.

This chapter, like the previous, is in four parts. The first section analyses the current NZES 2011 and outlines the Government's broad objectives in energy policy that affect the way energy security will be addressed. The second section will embark on a detailed analysis of the present use of energy security in political discourse under the Key National Government, again policy documents, speeches and media releases, will be analysed. It will show how the predominant use of energy security in the Ministry of Economic Development's energy 
strategy is completely different to the Clark Government's NZES 2007. The third section will argue that this is because the incumbent Government has a primary concern for security of supply. The fourth section will elaborate on the extent to which the Key Government has retracted the Clark Government's politicisation of energy security and climate change. There are far fewer references to energy security made in work of the Ministry for the Environment, Ministry for Transport, the Ministry of Defence and the Ministry of Foreign Affairs and Trade. In some instances, energy security is referenced by bureaucrats or politicians from these departments. However, it is no longer framed in terms of the language of threat, and more clearly in support of the National-led Government's economic concerns.

\section{The New Zealand Energy Strategy 2011 - 2021: developing our energy potential}

The Key Government has adopted the energy security and climate change framework from the Clark Government. The economic benefits of resource development however, are the primary focus of the new energy strategy. In the Foreword of the New Zealand Energy Strategy 2011 - 2021: developing our energy potential (NZES 2011) released in August 2011, acting Minister for Energy and Resources Hon Hekia Parata states that 'Globally, there are two challenges: energy security and responding to climate change.' 173 The response to these challenges is shaped by the key role the Government believes energy will play in the New Zealand economy. ${ }^{174}$ This role is clearly to develop New Zealand's renewable, petroleum and mineral resources, as she states: 'It is in New Zealand's interest to use its portfolio of energy resources to maximise economic opportunities in a way that is environmentally-responsible. ${ }^{175}$ Four priority areas will be focused on to achieve this. These are diverse resource development,

\footnotetext{
${ }^{173}$ Ministry of Economic Development, "New Zealand Energy Strategy 2011 - 2021: Developing Our Energy Potential." p. 1

${ }^{174}$ Ibid.p. 1

175 Ibid. p. 1
} 
environmental responsibility, achieving efficient use of energy, and promoting energy security and affordability. ${ }^{176}$ This is based on the recognition that renewables will help address the challenges of energy security and climate change. Fossil fuels however, will also continue to play an important role in the energy mix, as 'We cannot just turn off the tap in our journey to a lower carbon economy.'177

The Key Government uses a strategy of politicisation to prioritise the development of New Zealand's renewable, petroleum and mineral resources. It is in particular concern to the latter two that the Key Government shapes its own energy security rhetoric to legitimise its policy initiatives. First, the NZES 2011 states that New Zealand has an abundance of petroleum and mineral resources, and that '[d]eveloping these resources can contribute to energy security and provide export earnings for New Zealand.'178 Second, that through developing New Zealand's diverse energy portfolio (and mentioning petroleum reserves in particular) 'we contribute to global energy security - and have been commended for doing so by the International Energy Agency.' 179 These initiatives conflict with international efforts to address climate change, as the exploitation and consumption of coal and petroleum emit greenhouse gases. The Clark Government did not refer to New Zealand's role to help global energy security through the development of petroleum resources: simply, this would contrast too starkly with its aspiration to be an international leader on climate change. The Key Government however, brings the concern for global energy security to the forefront of its political agenda. The key features of the Key Government's presentation of energy security and energy issues will be outlined in the next sections. The analysis will elaborate on how the Key Government has appropriated energy security from the Clark Government, but shapes a

\footnotetext{
${ }^{176}$ Ibid. p. 1

177 Ibid. p. 1

178 Ibid. p. 1

179 Ibid. p. 3
} 
completely different rhetorical politicisation to support its distinct approach to energy, economic growth and climate change.

\section{Risk perceptions and economic growth}

In the NZES 2011 energy security is not politicised using the language of threat, nor does it imply that energy security should be governed within or above politics. The absence of the language of threat in the NZES 2011 is the most prominent point of difference with the NZES 2007. For instance, the current strategy does not refer to the energy security risks of oil dependency. The NZES 2011 states that most of New Zealand's oil is imported, 'which exposes the New Zealand economy to volatile international energy prices. More efficient use and greater use of alternative transport fuels can reduce our exposure to oil prices.' 180 This exposure to price is not presented as a risk that requires government leadership or strong policy response. The NZES 2011 expects the future price of oil to rise and become volatile. In response it states that non-renewables will continue to play a role in the energy mix alongside an increasing role of renewables. It also highlights how fuel prices affect consumer choice which affects 'the uptake of low-carbon fuels, new technologies and more efficient vehicles, vessels and aircraft.' ${ }^{181}$ Granted, and similar to the NZES 2007, the NZES 2011 references New Zealand's continued fulfilment of its IEA obligations to hedge against the risk of another serious international oil supply disruption. ${ }^{182}$ These concerns are not elaborated on, however.

Neither is there a sense of uncertainty conveyed in regards to the ability of domestic or international energy markets to ensure energy security. This is evident in statements made elsewhere in the NZES 2011. For instance, while citing the importance of secure and competitive markets, the NZES 2011 states that 'In the longer-term, investment in oil alternatives will boost transport energy

\footnotetext{
180 Ibid. p. 19

181 Ibid. p. 13

182 Ibid. p. 13
} 
security.' ${ }^{183}$ And, that '[t]he Government recognises that alternative transport fuels derived from a range of sources have the potential to contribute to the development of a more energy efficient transport system.'184 Energy security is the referent object in itself, and as a concept does not clearly include the presentation of risks associated to price or supply. In the draft $\mathrm{New}$ Zealand Energy Strategy (NZES 2010) released by the MED in 2010, the certainty of the market to determine the future of transport energy mix was even clearer: 'the Government will not pick winners: ultimately uptake of new energy sources and technologies will depend on the decisions made by consumers as they respond to prices.' 185 Policy documents and government departments in the Clark Government presented high oil prices and oil dependency as an energy security risk that will affect the New Zealand economy. This was presented as a reason to transition to a low-carbon economy, thus supporting the development of climate change policy. The NZES 2011 clearly does not frame the issues in the same way, nor does it convey a sense of insecurity in the market to make the transition to a low-carbon economy.

\section{Energy security: security of supply}

The Key National Government reconceptualises energy security. This is to align with its focus on domestic concerns for New Zealand's economic growth and the expectations of the voting-public. The emphasis on energy security's link to social and economic necessity prioritises these concerns. This is part of its rhetoric to legitimise the development New Zealand's resources. Prime Minister John Key stated that '[e]conomic growth is vital to providing New Zealanders and their families with the services and living standards they want and deserve.'186 First, in this respect, the NZES 2011 states that '[h]igh standards of energy security are

\footnotetext{
183 Ibid. p. 12

${ }^{184}$ Ibid. p. 19

185 _ - - , "Draft New Zealand Energy Strategy and the Draft New Zealand Energy Efficiency and Conservation Strategy," (Ministry of Economic Development, July 2010). p. 15

186 John Key, "Budget 2010 About Opportunity for Kiwis," ed. Releases (beehive.govt.nz, 20 May 2010).
} 
critical to New Zealand's economic performance and social well-being particularly in relation to oil and electricity.'187 As noted previously, the concern for economic growth has led to a focus in the NZES 2011 on developing New Zealand's abundance of renewable energy resources, as well as the less-well known petroleum and mineral reserves that can generate export earnings. The NZES 2011 states that it is a necessity to do so on economic grounds and therefore implies that the Government's policy response is a legitimate one: 'Developing all energy resources, subject to environmental considerations being managed, is necessary for our economic future.'188

The Government's support for the development of resources means that a concern for security of supply is prioritised in the NZES 2011's concept of energy security. The strategy states that it continues to hold the goal of 90 percent of electricity generation to be from renewable sources by 2025 but importantly adds 'providing this does not affect security of supply.'189 The NZES 2011 elaborates on this by stating that a price on carbon will enhance the competitiveness of renewable generation. It adds however, that achieving the 90 percent renewables target '[...] must not be at the expense of the security and reliability of our electricity supply. For the foreseeable future some fossil fuel generation will be required to support supply security.'190 The notion of security of supply is often referenced in discourse on energy issues, and is a prime concern for New Zealand's electricity sector. It is often referred to in relation to the reliability of a network that involves the delivery of electricity supply. ${ }^{191}$ Or, it can refer to

\footnotetext{
${ }_{187}$ Ministry of Economic Development, "New Zealand Energy Strategy 2011 - 2021: Developing Our Energy Potential." p. 12

188 Ibid. p. 3

189 Ibid. p. 6

${ }^{190}$ Ibid. p. 6

191 Transpower, "Security of Supply Important for South Island," scoop.co.nz,

http://www.scoop.co.nz/stories/BU0702/S00244.htm.;Orion, "Security of Supply Standard," oriongroup.co.nz, http://www.oriongroup.co.nz/publications-anddisclosures/consultation/security-of-supply-standard.aspx.
} 
resource development, such as wind projects or diversity, that add to supply. ${ }^{192}$ Likewise, the NZES 2011 states that 'Significant discoveries of oil and gas resources will help boost New Zealand's foreign earnings and domestic gas supplies.' 193 This statement invokes economic as well as security of supply benefits (in terms of increasing New Zealand supply of gas). This does not articulate risks to legitimise a policy response as the Clark Government did. Instead, the NZES 2011 supports its policy initiative by arguing that developing New Zealand's resources will be of combined economic and security of supply benefit.

The Labour-led Government's concept of energy security and climate change has been surpassed by a traditional focus on energy security; as the secure and reliable supply of energy. Scholars argue that security of supply is traditionally at the core of energy policy. ${ }^{194}$ This component of energy security has become inherent to the current model, and is common and persistent as a strategy today. ${ }^{195}$ The NZES 2011 states that it will promote 'energy security and affordability,' 196 and is consistent with its emphasis on the benefits of developing resources for energy supply, and maintaining security of supply in the electricity sector. This is not to suggest that energy prices are not concerns in New Zealand.

The NZES 2011 in fact, highlights price concerns and incorporates them into its argument for diverse resource development. It states that New Zealand's energy

\footnotetext{
192 The Main Report Group, "Electricity Supply Security: Grid to Upgrade to Help Power Supply Security," themainreport.co.nz, http://www.themainreport.co.nz/home/free-articles/electricitysupply-security-grid-upgrade-to-help-power-supply-security.html.

193 Ministry of Economic Development, "New Zealand Energy Strategy 2011 - 2021: Developing Our Energy Potential." p. 7

${ }^{194}$ Sauter, "E.U. Energy Security from an Agenda-Setting Perspective - Implications for E.U. Climate Change Policy?". p. 109; Helm, "Energy Policy: Security of Supply, Sustainability and Competition." P. 175 ; Sauter, "E.U. Energy Security from an Agenda-Setting Perspective Implications for E.U. Climate Change Policy?". p. 109;Chantale LaCasse and Andre Plourde, "On the Renewal of Concern for the Security of Oil Supply," Energy Journal 16, no. 2 (April 1995). p. 1 Cited in Bahgat, "Europe's Energy Security: Challenges and Opportunities." p. 965

${ }^{195}$ Collin Koh Mely Caballero-Anthony, "The Way Forward for Energy Security," Centre for NonTraditional Security (NTS) Studies: Policy Brief (December 2008). p. 1

196 Ministry of Economic Development, "New Zealand Energy Strategy 2011 - 2021: Developing Our Energy Potential." p. 1
} 
resources can further contribute to economic growth and promote the well-being of New Zealanders, by '[p]roviding diverse sources of reliable energy at competitive prices within New Zealand.' ${ }^{\prime 197}$ In regards to developing renewable resources, it states that using a wide range of energy will 'help make New Zealand more resilient to fluctuating commodity prices.' ${ }^{\prime 198}$ This is on the back of its recognition that the public is conscious of changes in electricity and petrol prices. In response the NZES 2011 states that it aims to keep energy as affordable as possible through competitive markets, and that New Zealand has lower energy prices than many other countries. ${ }^{199}$ This is more in reference to electricity than oil, as oil prices are set internationally and outside of the Government's control. In the domestic electricity market however, the Government cites its major review in 2009 (after public concern was raised over price) that included proposals to 'increase security of supply.'200

Professor Ralph Sims states that in terms of energy security, in general, there are two major trends. The first is security alone, where the policy focus is on the development of coal, gas and oil. The second is a notion of climate change security, where the policy focus is on renewable energy. ${ }^{201}$ Likewise, Dr Richard Hawke from the Ministry of Economic Development identified the twin challenges of energy and energy security, and energy security and climate change. ${ }^{202}$ Bearing this in mind the NZES 2011 does refer to energy security in relation to the future development of renewable resources, energy efficiency and the diversification of transport fuels. ${ }^{203}$ It continues to recognise that both energy security and climate change are difficult global challenges. The dominant political narrative however, articulates the benefits that diverse resource development will bring to energy security and the economy. Thus in the NZES

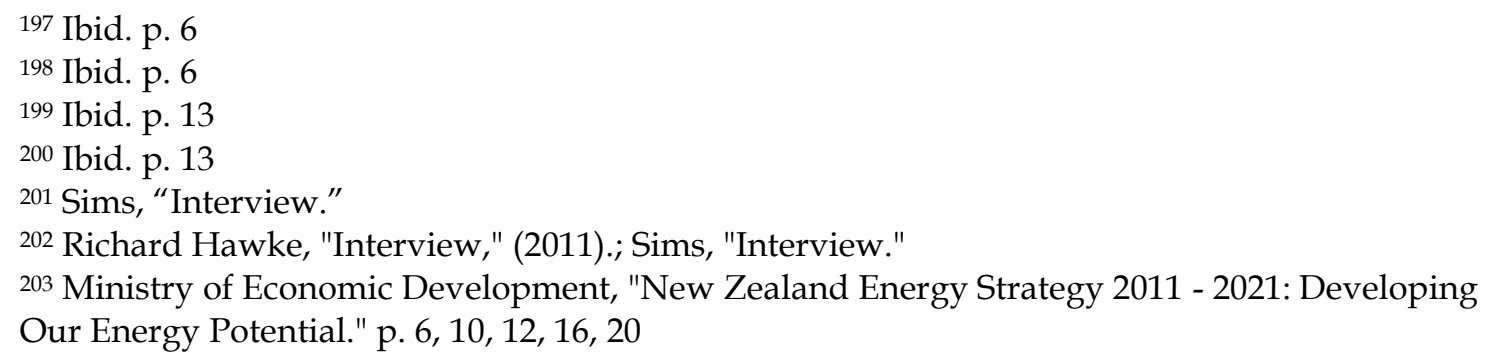


2011 energy security and climate change framework, energy security plays a very different role to what it did in the NZES 2007. Energy security is a distinct policy focus in itself, security alone, rather than something subsumed to the development of climate change policy.

The heightened concern for economic growth, and security of supply, mean that energy security embodies these core issues. In the NZES 2007 there was a heightened concern to address the urgent issue of climate change. Thus energy security embodied risks that would need to be addressed by the new climate change policy framework. In comparison, energy security in NZES 2011 is a collection of policy measures that align with those of economic growth. This policy focus is reminiscent of the domestic energy policies that IEA member states pursued after the 1973/74 oil shocks. These policies included diversification of member states' energy mix with alternative sources to oil (especially in power generation), increasing energy efficiency and development of their indigenous petroleum resources. ${ }^{204}$ First, under a heading What is energy security? the NZES states that 'On a system level, energy security is achieved when there are sufficient levels of energy resources reliably delivered via robust networks to meet changing demands over time.' 205 This refers to the ability of energy supply to meet demand which is more simply, security of supply. Second, it states that 'More efficient and flexible use of energy across society also contributes to system security.' 206 This perhaps refers to demand-side management of energy consumption, for instance, efficiency can be viewed as reducing energy waste and demand through the use of more fuel efficient cars. Flexibility is less clear, and could be related to the diversity of the energy system, or the idea of having choices between different forms of energy. Third, the NZES 2011 refers to the need for a resilient energy system. This is when the energy

\footnotetext{
204 Dieter Helm, "Energy Policy: Security of Supply, Sustainability and Competition." p. 181; MacNaughton, "Cooperating on Energy Policy: The Work of the International Energy Agency." p. 281

${ }^{205}$ Ministry of Economic Development, "New Zealand Energy Strategy 2011 - 2021: Developing Our Energy Potential." p. 13

${ }^{206}$ Ibid. p. 13
} 
system can 'cope with shocks and change, for example from natural disaster or international events.' ${ }^{207}$ And not surprisingly, it suggests that, having a diversity of sources, rather than being reliant on a few dominant sources, enhances energy security and resilience to these shocks. These are very general statements: specific risks to New Zealand's energy system are not elaborated on.

The ambiguity towards energy security's relationship to issues (other than supply disruptions) is clear when the NZES 2011 states that 'Security is enhanced where energy resources can be sustained environmentally, socially and economically over time. ${ }^{\prime 208}$ This primarily reflects a focus on secure supply of energy or in other words, security alone. First, this is clearly an idea of security in the long-term sense insofar as the supply of resources is sustained over time. Security however is used quite broadly, and it is not clear whether it is referring to any particular level of security, international, national or regional for instance. While it understands security to be related to environmental, social and economic issues, these concerns are not elaborated on. This reflects the degree of ambiguity towards energy security in the NZES 2011; it is generally referenced as a benefactor of energy policy designed to contribute to economic growth. If the integration of environmental concerns with security were more prominent in the document then energy security would be presented through both an environmental lens and an economic one. However this is not the case.

\section{Energy security through an economic lens}

The retraction of the Clark Government's politicised model of energy security is made clear in the MED's approach to climate change policy. The NZES 2011 tends to view energy security through an economic lens and separate to environmental concerns. First, the NZES 2011 does refer to climate change as a challenge. The Government aims to achieve its over-arching goals (prosperity,

${ }^{207}$ Ibid. p. 13

208 Ibid. p. 13 
security and opportunities) by focusing on four priority areas: diverse resource development, environmental responsibility, achieving efficient use of energy, and promoting energy security and affordability. Environmental responsibility is discussed, and has two areas of focus. First is best practice in environmental management for energy projects and second, is the reduction of energy-related greenhouse gas emissions. ${ }^{209}$ The former is in regard to a major programme review of the Resource Management Act, including reference to the National Policy Statement on renewable energy generation. The latter aims to monitor the adverse environmental effects of energy use and 'address issues relating to access to, or allocation of natural resources. ${ }^{210}$ Energy security is not associated to either of these policy initiatives, nor for instance, are the co-benefits between the reduction of GHG emissions and oil dependency presented in the tone of the NZES 2007. This is reflected elsewhere in the NZES 2011 where energy security is grafted onto longer-term projections of energy use. In these instances it is referred to in tandem with renewable resources, spoken of in relation to longerterm investments in alternatives to oil, and in particular, energy efficiency. ${ }^{211}$ Yet these are not immediately or clearly associated to the language of reducing energy-related greenhouse gas emissions, which are referenced in the section 'Environmental responsibility.'212

The emphasis in energy security on short-term risks to domestic security of supply and economic growth is reinforced by the omission of the term from policy documents, as well as in other government departments. The Clark Government politicised energy security across relevant government departments; energy security and climate change were issues that required an integrated policy response. The Key Government retracted this approach and centred energy security policy in the Ministry of Economic Development. In parliamentary Order Paper and Questions dated 23 September 2010, the Hon

\footnotetext{
209 Ibid. p. 8

210 Ibid. p. 8

211 Ibid. p. 3, 6, 8, 10, 12

212 Ibid. For example p. 8 - 9
} 
Trevor Mallard (Labour) inquired with the current Minister of Transport, whether he or the office had received any correspondence regarding 'global petroleum estimates and their impact on matters relating to his Transport portfolio since November 2008 [...]' The response of the Hon Steven Joyce (Minister of Transport) was that he had not, and that 'Energy security and supply issues are the purview of the Minister for Energy and Resources.' 213 The integration of energy security concerns with other relevant government departments has clearly failed to remain past the Clark Government.

The Key Government institutionally approaches energy security through an economic lens. Energy security is dealt with as an economic and development issue rather than integrated conceptually with environmental concerns in other departments. First, energy security is addressed in a structurally different way to the Clark Government, and is predominantly the focus and concern of the Ministry of Economic Development. Given also the omission of energy security in current Statement of Intents released by the Ministry for the Environment, ${ }^{214}$ and the infrequent use of the term in other documents, the predominant focus and narrative is centralised to the MED. Second, energy security is no longer used as the policy link between approaches to economic growth and climate change, as evident in comments made by the Minister for the Environment and Minister Responsible for Climate Change Issues, Hon Dr Nick Smith. Smith stated that the current '[g]overnment is committed to a carefully balanced agenda of both environmental and economic goals.'215 Energy security is not a feature of this agenda, nor it seems, is energy of primary strategic focus in the Ministry for the Environment's development of climate change policy.

The Ministry for the Environment is a major adviser on the sustainable development of New Zealand, which includes both international and domestic

\footnotetext{
213 Hon Trevor Mallard, 23 September 2010.

214 See Ministry for the Environment, "Statement of Intent 2009 - 2012," (Wellington: Ministry for the Environment, May 2009).; - - - "Statement of Intent 2010 - 2013,."

${ }^{215}$ Ministry for the Environment, "Statement of Intent 2010 - 2013,." p. 1
} 
matters related to climate change. ${ }^{216}$ In its Statement of Intent 2010-2013, it says it aims are to also give 'policy advice, regulatory reforms and programmes that the Government requires to ensure that resources are used productively while maintaining environmental values,'217 and that the Ministry will work with other central government agencies to give advice on issues related to natural resources. In the current strategy energy security is not mentioned. Climate change policy is mentioned, particularly matters concerning the implementation of the Emissions Trading Scheme. But there is no urgency to address these issues in the discourse. In terms of risks associated to energy, or energy related issues such as climate change, the Ministry for the Environment considers that,

Likely changes in our climate pose environmental, economic and social risks and opportunities. These risks and opportunities relate to rising sea levels, increases in flood events and droughts, changing wind and rainfall patterns, increased temperatures, and reduced frosts. ${ }^{218}$

The risks associated to climate change are presented as uncertain, there being opportunities as well. This is in contrast to the views of the MED under the Clark Government, which stated that 'there is a growing sense of urgency about the need to address the serious challenges of climate change.' ${ }^{219}$ Both Labour and National had different approaches to climate change and views on the urgency of the issue, as well as different ideas about how to address climate change policy. Previously under Labour, the urgency of climate change and the associated challenges of energy security meant that all relevant government departments concerning energy policy had to be engaged. The Clark Labour Government clearly tried to do this through bringing energy security to the forefront of departments' mandates.

\footnotetext{
216 Ibid. p. 4

217 Ibid. p. 3

218 Ibid. p. 11

${ }^{219}$ Ministry of Economic Development, "New Zealand Energy Strategy to 2050: Powering Our

Future." p. 13
} 
Where energy security was closely linked to climate change policy during the Clark Government, this is simply no longer the case in current strategy. Stuart Calman, the current Director of Climate Risk and Policy for the Ministry for the Environment, noted that there was quite an integration of climate change and energy security policy in previous government. Today, while the MfE and MED still operate in an integrated way to manage environmental, energy and economic issues, energy security tends to sit outside of this framework. ${ }^{220}$ Clearly also, the Key Government has a different approach to climate change policy which has affected how energy security is presented and dealt with in strategy. Unlike the Clark Government (who argued that New Zealand should be one of the first developed country's to reduce emissions), the current Government has a more cautious approach to climate change policy in the country's economic interests. The Minister Responsible for Climate Change Issues, Hon Dr Nick Smith argues that 'as a small open trading nation, accounting for $0.2 \%$ of global emissions, tough emission reduction policies would just export emission-intensive industries offshore.'221 Currently New Zealand's economic interests remain heavily tied to the agricultural sector, which also accounts for $50 \%$ of New Zealand's emissions. ${ }^{222} \mathrm{New}$ Zealand's international climate change policy retains a commitment to securing an effective global agreement. ${ }^{223}$ It also recognises the implications that commitments to emissions reductions will have on New Zealand's economy: specific priority areas include

\footnotetext{
220 Stuart Calman, "Interview," (2011).

${ }^{221}$ Hon Nick Smith, "Nick Smith: Climate Change and Business Conference," scoop.co.nz, http://www.scoop.co.nz/stories/PA0908/S00351.htm.

222 Ministry for the Environment, "Value of the Environment to the Economy," mfe.govt.nz, http://www.mfe.govt.nz/publications/ser/enz07-dec07/html/chapter2environment/page5.html.; Ministry of Economic Development, "Working with Sectors," med.govt.nz, http:// www.med.govt.nz/templates/StandardSummary__44546.aspx. Dairy is among the MED's priority industries for development and growth.

${ }^{223}$ Office of the Minister for Climate Change Issues and Office of the Associate Minister for Climate Change Issues (International Negotiations), "Climate Change International Negotiations: Update and New Zealand Position," ed. Ministry of Foreign Affairs and Trade (Wellington: mfat.govt.nz, 2009). p. 1
} 
agriculture and land use. ${ }^{224}$ A Cabinet paper states that 'It is imperative that we continue to build understanding amongst the international community of the challenges in reducing emissions from agriculture, in particular grazing livestock.'225 It is no surprise that the Government would focus on the agriculture sector rather than energy in climate change policy: the energy sector has a proportionally (by international standards) high use of renewable in New Zealand electricity generation and therefore, low emissions. Granted, Hon Dr Nick Smith noted that this has declined given the increase in coal generated production. ${ }^{226}$ Simply, the energy security related aspects of New Zealand's own climate change policy are not a predominant focus, therefore, why refer to energy security at all?

The unravelling of the Clark Government's politicised model of energy security and climate change is also made clear by the current ambiguity towards how energy security interrelates with other policy challenges. Where energy security is referenced by bureaucrats or officials from other departments, it is at times, ambiguous in regards to whether it is an environmental and economic issue or an economic issue alone. For instance, in the Ministry for the Environment the Hon Dr Nick Smith referred to greenhouse gas emissions in relation to energy security. In a Minister's Position Paper, Hon Dr Nick Smith stated that examples of non-economic co-benefits from moving to a low-carbon economy include 'increased energy security from less reliance on fossil fuels.' 227 Comparatively, in “Discussion Paper on Measures to Reduce Greenhouse Gas Emissions in New Zealand Post-2012" it states that,

\footnotetext{
224 Ministry of Foreign Affairs and Trade, "New Zealand's International Climate Change Policy," mfat.govt.nz, http://www.mfat.govt.nz/Foreign-Relations/1-Global-Issues/Environment/2Climate-Change/climate-change-policy.php.

225 Office of the Minister for Climate Change Issues and Office of the Associate Minister for Climate Change Issues (International Negotiations), "Climate Change International Negotiations: Update and New Zealand Position."

${ }^{226}$ Hon Dr Nick Smith, "Nick Smith: Climate Change and Business Conference," scoop.co.nz, http://www.scoop.co.nz/stories/PA0908/S00351.htm.

${ }^{227}$ Hon Nick Smith and Hon Tim Groser, "Ministers' Position Paper: Gazetting New Zealand's 2050 Emissions Target," Ministry for the Environment, http://www.mfe.govt.nz/publications/climate/nz-2050-emissions-target/gazetting-nz-2050emissions-target.pdf. p. 4
} 
[...] even if domestic emission reductions were more costly in New Zealand than in other countries, it could still be in the national interest to pursue domestic emission reductions because of other co-benefits, such as economic development, energy security and local environmental gains. ${ }^{228}$

While Hon Dr Nick Smith's statement argues that reducing reliance on fossil fuels is a non-economic benefit (but a benefit nonetheless for energy security and climate change), the discussion paper suggests that it could be in our national interest to pursue emission reductions, for co-benefits of both energy security and economic development. There seems to be shifting views on the economic and energy security benefits of investing in more robust climate change policy. On one hand, energy security is a non-economic co-benefit of reduced reliance on fossil fuels. On the other hand, it is referred to alongside economic co-benefits to suggest that it is in the national interest to pursue emissions reductions.

Energy security no longer has a clear role in international climate change policy in the Ministry for the Environment under the Key Government. Similarly, energy security is no longer used in foreign policy documents released under the Ministry of Foreign Affairs and Trade (MFAT). MFAT's overarching mission is that 'New Zealand's security and prosperity interests are advanced and protected, our voice is heard abroad.' 229 It clearly articulates its current objective to further New Zealand's economic growth prospects. ${ }^{230}$ First, energy security is not referenced in MFAT's strategic documents, yet energy supply disruptions are presented as direct threats to 'economic security.' In an explanation of New Zealand's current APEC priorities in regards to business costs and behind-border reforms in the World Trade Organisation 'DOHA Development Round' (DDA)

\footnotetext{
228Ibid. p. 4

${ }^{229}$ Ministry of Foreign Affairs and Trade, "Statement of Intent 2010 - 2013," (New Zealand Government, 2010).p. 10

${ }^{230}$ Ibid. p. 8
} 
Negotiations and Free trade Agreements/Regional Trade Agreements, it states the following in relation to security:

Neither New Zealand's economic prosperity nor that of the region takes place in a vacuum. Economic security can be threatened by terrorism, threats to health or potential disruptions to energy supplies. New Zealand places a high priority on working with its APEC partners on these broader issues, which we see as a complementary mission to APEC's core trade and economic work. ${ }^{231}$

The referent object is economic security which is indirectly linked to New Zealand's own economic prosperity in the Asia-Pacific region. Economic security in this sense refers broadly to a regional dynamic. The language of threat is used in reference to supply disruptions. In some respects then, current government departments appear to be talking past each-other. At the domestic policy level in the NZES 2011 disruptions to energy supplies are perceived as a security of supply issue in electricity generation and in oil security. MFAT links energy supply concerns directly to the term 'economic security.'

The policy response and interpretation of international energy security is clearly the purview of the MED. Under the Clark Government, energy security was included in the mandates of MFAT and MfE, recognised as part of the operating environment. This is simply not the case under the Key National Government. First, the NZES 2011 recognises international concerns for energy security, stating that 'countries are striving to improve energy security, reduce pressure on the environment and reduce greenhouse gas emissions.'232 As noted previously in this chapter, the NZES 2011 also refers to the challenges of energy security and

\footnotetext{
$231 \quad---$, "Asia-Pacific Economic Cooperation (Apec)," mfat.govt.nz, http://www.mfat.govt.nz/Media-and-publications/Publications/Trade-matters/0-apec.php. 232 Ministry of Economic Development, "New Zealand Energy Strategy 2011 - 2021: Developing Our Energy Potential." p. 2
} 
climate change in the global context. ${ }^{233}$ Thus the interpretation of these challenges is through an economic lens. For instance, '[g]lobal challenges of energy supply and climate change will increasingly influence the availability and cost of energy.'234 The policy response to these concerns is first related to the economy and second, to the supply and use of energy. The NZES 2011 states that `New Zealand future competitiveness will [...] require innovative solutions in the sources and uses of energy - both renewable and non-renewable.'235 It is clearly stated in the passage that supply is responded to by developing all energy resources, and use the promotion of energy efficient practices. ${ }^{236}$ There are common economic benefits highlighted for both policies. However, developing resources is 'subject to environmental considerations' while efficient use of energy will 'reduce greenhouse gas emissions.' ${ }^{237}$ Concern for energy security, as the supply of energy through developing diverse resources, is in opposition to climate change policy. Energy security is considered something that is subject to environment considerations. It is not, as it was in the Clark Government, articulated as a co-benefit of climate change policy.

The MED's interpretation of the global challenge of energy security is shaped by the economic opportunities presented by increasing world energy demand. The NZES 2011 states that 'For the next few decades at least, the world and New Zealand will need oil, gas and coal.' 238 It also argues that there is an opportunity to develop New Zealand's potential non-renewable resources that the country should grasp, '[p]rovided that the very highest standards of environmental protection are applied.' ${ }^{239}$ Not only can New Zealand gain from this, in export earnings, but as previously noted the NZES 2011 states that this will contribute to 'global energy security.'240 Energy development in other countries, according to

\footnotetext{
233 Ibid. p. 1, p. 3

234 Ibid. p. 3

235 Ibid. p. 3

236 Ibid. p. 3

237 Ibid. p. 3

238 Ibid. p. 2

239 Ibid. p. 3

240 Ibid. p. 2
} 
the NZES 2011, is also interpreted as an economic benefit for New Zealand. It states that New Zealand's expertise and technologies can 'assist other countries to develop their energy resources and generate income for New Zealand.' ${ }^{241}$ It is clear that the Key Government frames global energy security concerns as economic opportunities rather than risks of the international operating environment. This is a different approach to the Clark Labour Government who integrated the mandates of MFAT and MfE with the NZES 2007. This meant that international energy security issues were approached through a dual environmental and economic lens. In other words, energy security was integrated with the policy response to climate change and factored in on economic development aid in other countries.

New Zealand's global role to contribute to energy security, and the economic benefits of doing so, are not articulated in the policy mandate of MFAT. This is further evidence of the centralisation of policy response to international energy security concerns in the MED. And second, that these concerns are viewed through an economic lens and not as risks to international stability that require policy attention, or strong integration with economic development and climate change adaptation policy. In MFAT's Statement of Intent $2010-2013,{ }^{242}$ it refers to energy in a section entitled 'Our Operating Environment: International Trends', where 'Competition for natural resources (including energy, water and food) is intensifying, including for fisheries in New Zealand's region.' ${ }^{243}$ While this is quite broad, later examples in the document show that in terms of natural resources, New Zealand focuses on fisheries and climate change. For instance, it states that '[i]n recent years our understanding of threats to New Zealand's prosperity has broadened to include environmental threats such as climate change, and the unsustainable use of shared resources, such as high seas fisheries.'244 In particular where common resources are concerned MFAT seeks to

\footnotetext{
241 Ibid. p. 2

242 Referred to here on as SOI

243 Ministry of Foreign Affairs and Trade, "Statement of Intent 2010 - 2013." p. 15

244 Ibid. p. 12 See also p. 23, under 'Climate change and natural resources'
} 
achieve 'an international environmental and natural resources agenda that advances New Zealand's interests and supports New Zealand's economic competitiveness.' ${ }^{245}$ Among the high-level measures it identifies reducing the number of whales caught in the Southern Ocean, reduction in illegal fishing, concerns for international rules and food markets, and 'a world on track' to reduce greenhouse-gas emissions by $50 \%$ by 2050.246 Evidently energy concerns do exist but currently they are not MFAT's primary focus, but rather an indirect concern.

MFAT's SOI 2010-2013 states that it intends to 'work through bilateral and regional mechanisms on trade, fisheries, transport, infrastructure, energy and tourism to help Pacific countries to grow their economies.' ${ }^{247}$ In this regard, MFAT intends to strengthen these relationships. ${ }^{248}$ Renewable energy is mentioned by the Hon Murray McCully, Minister of Foreign Affairs, in reference to strengthening New Zealand's leadership in the South Pacific through using Official Development Assistance (ODA). ${ }^{249}$ Development is related to New Zealand's security and prosperity interests insofar as 'Our ability to turn international connections into economic growth relies on the existence of a stable and secure environment.' 250 Contributing to global security and development in poorer nations will contribute to this stable and secure environment. ${ }^{251}$ Energy concerns in international affairs are centred in development in the Pacific and at best, are part of a broader package to contribute to international stability through development aid in the Pacific region.

The New Zealand Defence White Paper, released in 2010 by the Ministry of Defence, is consistent with MFAT's approach to energy concerns. It does not present any specific energy security concerns in New Zealand's interest to

\footnotetext{
245 Ibid. p. 22

246 Ibid. p. 22

247 Ibid. p. 19

248 Ibid. p. 26

249 Ibid. p. 6

250 Ibid. p. 12

251 Ibid. p. 12
} 
address. For instance, it mentions resource competition with indirect consideration of energy therein, where '[a]s the world's population increases, resources (water, food, energy and minerals) are likely to become scarce in some regions, leading to increased competition for their allocation.' ${ }^{252}$ In broader terms of 'resources' there is a reference to competition and its effects on regional stability in the Asia-Pacific. Under 'Open trade routes' it states that competing territorial claims in parts of maritime Asia will remain contested. While this competition may be expressed militarily, it argues that shared economic benefits could promote regional stability. However, 'the combination of resource competition and narrowly defined national interest will continue to be a volatile mix.'253

This omission of energy security from foreign policy mandates was not immediately evident at the beginning of the Key Government's term; only appearing later when the first draft New Zealand Energy Strategy was released in 2010. In a Post-election brief released by MFAT, closely after the National Party won the general election in November 2008, it stated that 'climate change increasingly needs to be seen as an energy security, economic and development issue, as well as an environmental one.'254 The Post-election brief suggests that initially, the Clark Government's politicisation of energy security and climate change in international as well as domestic strategy remained institutionally. The whole-of-government approach to these concerns however, has been clearly retracted. The NZES 2011 is the only document that gives a policy response to energy security and climate change. But the role of energy security in this framework (in comparison to the Clark Government) is reconceptualised. The NZES 2011 frames its international response to global energy security through an economic lens. This policy response is no longer institutionally integrated with departments dealing with international climate change negotiations (MFAT and

\footnotetext{
${ }^{252}$ Ministry of Defence, "Defence White Paper " (Wellington: Ministry of Defence,, 2010). p. 26 253 Ibid. p.3 2

${ }^{254}$ Ministry of Foreign Affairs and Trade, "3 Other Key Relationships: The United States (Us)," Ministry of Foreign Affairs and Trade: Post-Election Brief (mfat.govt.nz, November 2008). p. 29
} 
MFE). The NZES 2011 redefines the place of energy security on the international agenda as an opportunity for economic growth. It is no longer a strategic focus for New Zealand's international development aid. The Clark Labour Government comparatively, instituted the climate change, economic growth and energy security nexus into its development strategies.

\section{Conclusion}

The Key Government has adopted the Clark Government's energy security and climate change framework, but has reshaped the energy security rhetoric to suit its policy initiatives. This is for all intents and purposes, a strategy of politicisation. Energy security embodies a heightened concern for security of supply and global supply challenges. The MED prioritises these concerns in its concept of energy security. This forms the basis of its rhetorical politicisation of energy security to legitimise the heightened policy focus on developing all energy resources. This is not bolstered by articulating energy security risks, as the Clark Government did, but by clearly arguing for the benefits of this policy for the New Zealand economy. Centralising energy security concerns to the MED is also strategic and telling of the Key Government's perspective of energy security's place in policy; as an economic concern and policy focus alone, rather than something that is addressed through climate change policy outright. In comparison, highlighting threat or risk suggests that something needs to be done to mitigate these effects. To refer back to the introduction, security is a 'move that takes politics beyond the established rules of the game and frames the issue either as a special kind of politics or as above politics.'255 The politicisation of energy security and climate change under the Clark Government brought these risks to the forefront of debate, and sought to address them in an integrated way across government departments. Notably, it introduced government initiatives such as the National Policy Statement on renewable electricity generation in support of climate change objectives. It has more hall-marks of a security

${ }^{255}$ Buzan, Waever, and Wilde, Security: A New Framework for Analysis. p. 23, 
argument than the Key Government's current rhetoric. The tactical appeal of politicisation is no less powerful however, when energy security and economic concerns are invoked. The Key Government's rhetoric prioritises global energy security and economic opportunities in capitalising on renewable, petroleum and mineral resources. This clearly aims to legitimise its energy policy initiatives. Energy security is used to support two very different priorities in energy policy. Why has this happened? Are there other factors involved that have shaped this process, or does it really come down to the government in power? The next chapter will explore the factors that have shaped the politicisation of energy security and climate change in New Zealand's domestic and foreign affairs, and the subsequent restructuring of energy policy when the Key Government came into power. This will provide further insight into what has shaped New Zealand's energy policy, and the nature of the country's energy politics. 


\section{Chapter Five \\ Energy security and political agendas}

There have been two distinct rhetorical politicisations of energy security between the Key and Clark Governments. The Clark Labour Government's rhetorical politicisation emphasised energy security risks in order to legitimise its robust climate change policy. The Key National Government, in comparison, has prioritised security of supply in its rhetorical politicisation of energy security. This distinct energy security rhetoric aims to legitimise its policy to develop New Zealand's energy resources. This chapter will examine why this shift has occurred. It will argue that because politicisation means an issue is debated and addressed within politics, it set the course for contestable views of energy security to develop on the political agenda. Two different rhetorical politicisations then manifested in policy because of three key factors. First, is the formative stage of energy policy in New Zealand. Second, the divisive constituency views of energy security. Third, are the economic and political conditions that favoured as well as hindered the development of each Government's energy policy. These key factors will be highlighted across two main sections that analyse the development of each Government's energy policy. The analysis will show how their distinct rhetorical politicisations of energy security were shaped by the favourable resonating conditions they could draw on, and the hindering conditions they defended their respective strategies against.

\section{The development of energy policy under the Clark Labour Government}

The Clark Government's development of energy policy was against the backdrop of a strong, free-market approach to energy security. Its argument for a stronger role of government in the energy sector therefore, had to be convincing. Government leadership in the energy market through robust energy policy was 
not established prior to the Clark Government. In New Zealand, since neo-liberal restructuring in the mid-1980s market competition has determined the direction of the domestic energy market, not the government. As Barry Barton points out, during this time of reform energy planning on the part of government went out of fashion. The Ministry of Energy was eliminated in 1989 as the government shed its ownership interests in oil and gas, and introduced commercial objectives into state-owned enterprises in electricity and coal. ${ }^{256}$ Energy policy in many ways is relatively new to New Zealand, and the reliance in the market to deliver energy security remains a strong feature of the domestic policy environment. ${ }^{257}$ The fact that energy policy is not well-established in New Zealand worked in the Clark Government's favour: there was a relatively clean slate as it were, to develop an energy policy. This would be successful particularly if perceived market failures of the energy system could be capitalised on. This has been used in energy security arguments before, where a market failure (or risk) is highlighted to invoke the need for a government response. This is exactly what the Clark Government did.

The Clark Government's rhetorical politicisation of energy security drew on resonating conditions in events that turned political and public attention to the risks of New Zealand's energy system. The Clark Government was attuned to these risks and politicised them in the development of its energy policy. In 2004 Labour MP David Parker (before he was appointed Minister of Energy) stated that '[e]nergy policy is being given heightened consideration worldwide due to dramatic price increases, potential future constraints on fuel supplies and widespread acknowledgement of the threat that climate change poses [...] energy is one of the most important issues facing the world. New Zealand is no exception.'258 The public was also aware of these risks. First, several energy issues and concerns had arisen in the early 2000s. New Zealand had faced extreme dry

\footnotetext{
256 Barton et al., Energy Security: Managing Risk in a Dynamic Legal Environment. p. 375

${ }^{257}$ Barton, "Interview."; Sims, "Interview."

258 Ministry of Economic Development, "Developing a New Zealand Energy Strategy - Terms of

Reference," (Wellington2004). p. 1
} 
periods in 1992, 2001 and 2003, which placed considerable pressure on the hydrodams. This led to national energy savings campaigns to reduce the risk of shortages. ${ }^{259}$ Furthermore, the Maui gas field was depleting and concerns for New Zealand's gas supply arose. ${ }^{260}$ The capacity of New Zealand's energy system to keep up with rising demand was put into question: the years after 2000 saw a rise in economic activity and thus a rise in demand for energy resources. ${ }^{261}$ Rising oil prices and debate over the capacity in the international oil system to keep up with demand were also prevalent in the public media. ${ }^{262}$

A second favourable condition for politicisation was that political attention had turned to climate change policy, as during this time New Zealand ratified the Kyoto Protocol.263 This would require New Zealand to develop strategies to reduce greenhouse gas emissions in line with its Kyoto commitments. In 2004 the then Minister for Energy, Hon Pete Hodgson, stated that two challenges would force a radically different energy system to emerge, 'One is the coming peak global oil production, which will probably occur within our lifetimes or our children's. The other is global climate change. Both of these render our current energy habits unsustainable.' ${ }^{264}$ Furthermore, 'to make progress towards a sustainable energy system we need a long-term view of our interests and those of future generations of New Zealanders.' ${ }^{265}$ This required the government to develop climate change policy.

\footnotetext{
259 - - - , "Sustainable Energy - Summary." p. 3; Barton et al., Energy Security: Managing Risk in a Dynamic Legal Environment. p. 373 - 374

${ }^{260}$ Ministry of Economic Development, "Sustainable Energy - Summary." p. 3; Barton et al., Energy Security: Managing Risk in a Dynamic Legal Environment. p. 373 - 374

${ }^{261}$ David Parker, "Interview", 2011

262 Ellen Read and Reuters, "Oil Price Increases About to Hit Home," nzherald.co.nz, http://www.nzherald.co.nz/markets/news/article.cfm?c_id=62\&objectid=3581165.; RNZ, "Petrol Prices Follow Oil Higher," tvnz.co.nz, http://tvnz.co.nz/view/page/411319/593350.; Interactive/AAP, "Kiwis Feel Price Pinch, More to Come," tvnz.co.nz, http://tvnz.co.nz/content/425389/425823.html.

${ }^{263}$ Ministry of Economic Development, "Sustainable Energy - Summary." p. 3

264 Ibid.p. 2

265 Ibid. p. 2
} 
Public and stakeholder resistance to climate change policy however, created a hindrance to policy development. As Geoff Bertram and Simon Terry point out, both Labour and National accept that 'a price on carbon' is essential to a policy response to climate change. ${ }^{266}$ The Labour Government's attempts however, to introduce a price via a carbon tax or similar 'have repeatedly been abandoned in the face of strong lobbying by major emitters and their supporters.' 267 Opposition to the 'fart-tax', in reference to the carbon price Labour proposed for the release of methane gas in the agricultural sector, was an example of this lobbying and resistance. Despite this resistance, the Clark Government decided to sacrifice a large amount of political capital and continue with the formation of a New Zealand energy strategy. 268 This resistance shaped the Clark Government's response in energy policy.

The Clark Government's politicisation of energy security legitimised its robust climate change policy in the face of this opposition. The Clark Government politicised energy security risks that affect the New Zealand economy and that bring uncertainty to the domestic energy market. Furthermore, it argued that these risks are exacerbated if New Zealand does not form a robust policy response to climate change. This effectively highlights that while climate change policy will impact on New Zealand's agricultural sector, not doing anything will exacerbate the risks to long-term energy security and thus to the national economy. When recently interviewed for this thesis, David Parker noted that the government wanted to show that they were prepared to say that 'we're going to change,' and would do so through developing a national energy strategy. ${ }^{269}$ This was on the back of failed climate change policy initiatives resisted by lobbying in the agricultural sector. Bearing this in mind, it makes political sense to re-focus the debate to the very thing that ensures New Zealand's key industries function:

\footnotetext{
266 Geoff Bertram and Simon Terry, The Carbon Challenge: New Zealand's Emissions Trading Scheme (Wellington: Bridget Williams Books, 2010). p. 18

${ }^{267}$ Geoff Bertram and Simon Terry, The Carbon Challenge: New Zealand's Emissions Trading Scheme

(Wellington: Bridget Williams Books, 2010). p. 18

${ }^{268}$ David Parker, "Interview," (2011).

269 Ibid.
} 
the secure, reliable and affordable supply of energy. Highlighting that current business-as-usual practice is putting the future of energy security at risk provides a counter-argument to opposition of climate change policy.

There were favourable political and economic conditions that the Government capitalised on, and less ideal resistance that shaped its approach to energy security in policy. No doubt, the election of the Clark Government to its third term in 2005 gave it the opportunity to pursue its new energy policy. According to David Parker, the country was enjoying a relative period of prosperity which meant the public was open to thinking about other issues, particularly climate change. ${ }^{270}$ The Government decided to make a move, as it were, and push its political agenda for climate change further into the heart of economic policyformation. ${ }^{271}$ With the backing of Prime Minister Helen Clark and Michael Cullen, David Parker was instructed to go ahead and get 'the policy settings right.'272 These policy settings clearly involved giving a clear indication that energy security concerns and climate concern would be addressed at the same time, evident in the NZES 2007.

The Clark Government used its political power to restructure how energy security, climate change and economic issues were to be institutionally addressed. The Government's politicisation of energy security embodied a tactical move to institutionally support the new approach to energy policy. This involved placing climate change at the heart of energy policy and economic development by integrating the ministerial portfolios and centering the move in the MED. First, in the Government's third term David Parker was made both the Minister of Energy and Minister Responsible for Climate Change Issues by Prime Minister Helen Clark, who also gave him co-signing authority over papers from other ministries that impacted on his climate change portfolio. ${ }^{273}$ Second, the Government's goal

\footnotetext{
270 Ibid.

271 Ibid.

272 Ibid.

273 Ibid.
} 
was to provide certainty on the future policy and regulatory environment, increase awareness of the energy challenges, develop a more informed and inclusive decision-making process, through an all-encompassing government process led primarily by the Ministry of Economic Development. 274 The Clark Government wanted not only to push energy policy in a particular direction, but also wanted to change the institutions and the processes through which this policy would be formed. This move faced obstacles. Here David Parker notes that the policy pursued when he was Minister met with some resistance from the MED. According to Parker, the MED was 'more fixated on energy security rather than climate change,' and asked him whether the strategy was about climate change or economic growth and energy security. ${ }^{275}$ Thus between bureaucrats and politicians, risks and the appropriate policy response are contested.

This level of debate on energy security creates an environment in which politicians need to clearly argue their case convincingly to win support. Thus the presentations of energy security, as discussed in Chapters Three and Four, pander to the audience of energy policy; political and government opponents, as well as key stakeholders and market actors in the energy sector. This is particularly relevant to the Clark Government that clearly faced resistance from the Opposition and within government departments for its approach to energy security and climate change.

The Government's energy policy was limited by particular resistance from market participants and key stakeholders. This group shaped its own argument for energy security in response to the NZES 2007. In order to argue its own case against NZES 2007, market participants used security arguments to highlight the threats climate change policy would pose to New Zealand's energy security. As evident in the submissions to the NZES 2007 there was a concern that climate change policies would threaten security of supply. The electricity generator and

\footnotetext{
${ }^{274}$ Ministry of Economic Development, "Developing a New Zealand Energy Strategy - Terms of Reference." p. 3, 4, 5

275 David Parker, "Interview," (2011).
} 
retail company Genesis Energy argued that a more aggressive approach to reducing thermal generation would place 'security of supply' at risk, for instance, if the gas-fired Huntly Power station was phased out of electricity generation too quickly. ${ }^{276}$ Likewise, the submission made by the Gas and LPG Associations stated that 'Insufficient attention was paid to [...] the contribution other fuels can make to energy security and diversity.'277 Todd Energy New Zealand (which owns and operates in natural gas, oil, LPG, electricity, as well as cogeneration and solar heating) ${ }^{278}$ used threat language in specific reference to the National Policy Statement on renewable electricity generation. The energy company stated that where 'there are very good reasons for thinking that overzealous pursuit of renewable energy generation in the medium term (as in the $90 \%$ by 2025 objective) could [...] pose a threat to New Zealand's energy security. ${ }^{279}$ For energy industry participants in gas and oil extraction, and electricity generation, energy security was therefore presented as an area of concern, and at risk, if renewable energy was too heavily focused on by the Government. Todd Energy New Zealand politicised energy security in this way in order to argue against the NZES 2007 policy initiatives.

The Clark Government's rhetorical politicisation of energy security responded to criticisms in a symbolic way; arguing that the Government could address energy security through climate change policy. Second, by highlighting the long-term risks to energy security, and the greater urgency to address climate change, it aimed to prioritise these concerns over short-term risks to security of supply

\footnotetext{
276 Genesis Energy, "Target 2030 Planning the Future of New Zealand Energy: Integrated Submission on Four Consultation Papers," ed. Murray Jackson (30 March 2007). p. 2

277 Gas and LPG Associations of New Zealand, "Submission on the Draft NZ Energy Strategy and the Draft Nzeecs: Comments from the Gas and Lpg Associations," ed. Jim Coe (Wellington30 March 2007).; See also Aotearoa Wave and Tidal Energy Association (AWATEA), "Submission on the New Zealand Energy Strategy, New Zealand Energy Efficiency and Conservation Strategy, Energy Research Roadmap and Related Climate Change Documents," ed. AWATEA (Wellington).

278 Todd Energy New Zealand, "Who We Are," toddenergy.co.nz, http://www.toddenergy.co.nz/who-we-are.

279 Bill Armstrong, "Todd Energy Submission on National Policy Statement on Renewable Electricity Generation " mfe.govt.co.nz, http://www.mfe.govt.nz/rma/central/nps/generation/submissions/77-todd-enegry.pdf. p. 6
} 
articulated by the market. But different perceptions not only of risks but how they should be governed, is a crucial tension at the heart of the energy policy debate. Securitisation Theory purports that the language of threat is a tactical move, and used to legitimise governance of an issue within or above politics. Under the Clark Government energy security embodied risks to the energy system, and was presented as a benefit of climate change policy. Climate change policy required stronger leadership of government in the market through policy initiatives that promote renewable energy. This was particularly difficult facing a strong, free-market culture that dominates the domestic policy environment. ${ }^{280}$ Market participants and stakeholders who criticised the NZES 2007 argued that energy security was put at risk by the policy interventions. Energy security embodies a tactical move to legitimise this position.

These contestable views on energy security have been given voice through the Clark Government's initial politicisation of the concept. Clearly energy security risks have been politicised in response and used in New Zealand energy politics to argue against climate change policy. More so perhaps than promoting change. The prominent New Zealand mining company Solid Energy argued that in the case that New Zealand adopted climate change strategies which 'addressed risks of high future energy costs but assumed weak [and] early international on climate change,'281 the company would take measures to address energy security and affordability. These measures included the accelerated development of indigenous energy resources. This is a more subtle argument which, in fact, argues that if New Zealand adopts early climate change policy this would affect energy security and affordability, and hence, Solid Energy would need to address this through increasing security of supply by developing resources. Professor Ralph Sims of Massey University states that 'security is first and foremost

\footnotetext{
280 Sims, "Interview."; Barton, "Interview."; International Energy Agency, "Executive Summary and Key Recommendations," http://www.iea.org/Textbase/npsum/NewZealand2010SUM.pdf.; International Enegry Agency, "New Zealand 2006 Review," in Energy Policies of IEA Countries (Paris: IEA/OECD, 2006). p. 11 281 Solid Energy, "Submission on Draft New Zealand Energy and Climate Change Strategies," ed. Solid Energy (March 2007). p. 14
} 
carrying on with business-as-usual, regardless of where the energy comes from.'282 Evidently energy supply is important in the mid-term, and that in spite of the effects that developing gas, coal and petroleum resources would have on greenhouse gas emissions (consumed on New Zealand shores or overseas), energy security alone remains the priority. This is as equally tactical and convenient an argument as the NZES 2007's emphasis on long-term risks to energy security to support climate change policy.

The Clark Government's rhetorical politicisation of energy security was limited by the opposition, thus its politicisation did not lead to a successful institutionalisation. The NZES 2007 emphasises long-term risks to the energy system, such as oil dependency and the uncertainty in the domestic energy market, and the need to address climate change in policy; all of which are exacerbated if the Government does not give clear signals and leadership in the energy sector. This view though, is hindered by the concern for security of supply that is epitomised in the current energy strategy. Barry Barton points out that energy security has a time dimension, where some problems are short-term, and that risk is difficult to evaluate. ${ }^{283}$ He states that,

Security, after all, is no more the protection from the risk of harm. Risk is notoriously difficult for individuals to evaluate. [...] And we are all at sea in estimating the risk of events of low probability. These tendencies affect political action, so that we invest far more in maintaining some kinds of security than others. $^{284}$

This explains why in the energy security debate today the Hon Gerry Brownlee argued that 'Improving energy security and energy affordability are key concerns

\footnotetext{
282 Sims, "Interview."

283 Barton et al., Energy Security: Managing Risk in a Dynamic Legal Environment. p. 9 and secondly, that the concept also invites thoughts about risk.

${ }^{284}$ Barry Barton et al., Energy Security: Managing Risk in a Dynamic Legal Environment. p. 9
} 
[...] In my view, these issues were not accorded a sufficiently strong priority in the 2007 NZES.' 285 The NZES 2007 addressed long-term risks of energy security and climate change, while the Key National Government has greater concern for short-term risks of climate change policy on security of supply. In response, the current energy spokesman for Labour Charles Chauvel, argues that '[t]he confusion and uncertainty created by National's climate change policy is putting New Zealand's energy security at risk.' 286

The two Governments' rhetorical politicisations of energy security resonate with the two sides of the divisive constituencies in the energy debate. First, the way energy security was presented in current strategy aligns to the language used by market actors and key stakeholders who criticised aspects of the NZES 2007. Security of supply is emphasised in the concept of energy security by this group. Second, and one point of difference between the criticisms and the NZES 2011, the language of threat is used by market actors critiquing the NZES 2007. Energy security is put at risk by policy interventions in the market. This is to prioritise a business-as-usual approach of government in energy policy. While the language used is different, the political agendas of the Key Government and these market participants align in the common perception that the market will determine the direction of energy choices, energy use and energy security. Hence, as will be shown in the next section, the Key National Government drew on this constituency to support its energy strategy. As a result energy security was shaped by the views of this group, and set to align with the goals of the incumbent Government in the wake of a the Global Financial Crisis. The Key Government also faced opposition from a constituency group whose energy security rhetoric aligns more closely with the Clark Labour Government.

\footnotetext{
285 Brownlee, "Government Consulting on Energy Policy."

286 Charles Chauvel, "ETS Uncertainty Points to Serious Energy Problems," labour.org.nz, http://www.labour.org.nz/news/ets-uncertainty-points-serious-energy-problems.
} 


\section{The development of energy policy under the Key National Government}

The Key National Government adopted the energy security label, but for a different political agenda. Clearly it would, and did, find support in its constituency who had opposed the Clark Government's energy security strategy. First and foremost however, the unravelling of the Clark Government's particular politicisation of energy security and climate change was in part, due to the loss in the general election to the National Party in November 2008. The opposing side now had the opportunity to prioritise its views on energy security in policy. Upon the release of the initial draft NZES in 2010, the MED stated that 'The strategies have been updated to align with current government energy policy priorities and to reflect a stronger focus on economic development.' 287 Second, the climate change and energy portfolios are no longer held by the same Minister. The Hon Gerry Brownlee was appointed Minister for Energy and Resources, while Hon Dr Nick Smith was appointed the Minister for Climate Change Issues, and Hon Tim Groser became the Minister Responsible for International Climate Change negotiations. The rhetorical politicisation of energy security that highlighted risks in support of domestic climate change policy, was simply no longer applicable to the strategic focus of the National Government. And the Clark Government's approach to energy policy-formation was also no longer applicable.

From the outset, the National Government wanted to emphasise the importance of security of supply in energy policy. As stated previously, prior to the election in November 2008, the then National Party Energy spokesman Gerry Brownlee stated that 'a National-led Government will maintain an unrelenting focus on security of energy supply.'288 This could be considered in line with early efforts to

\footnotetext{
287 Brownlee, "Government Consulting on Energy Policy."

288 Hon Gerry Brownlee, "Security Underlines National's Energy Policy," national.org.nz, http:/ / www.national.org.nz/ Article.aspx?ArticleID=28380.
} 
repeal the Electricity (Renewable Preference) Bill in parliament so that all resources would hold a short-term and mid-term role in base-load generation, as well as giving a clear indication in the draft NZES 2010 to develop New Zealand's indigenous resources. Upon election, the Hon Gerry Brownlee stated that energy security and affordability had not been addressed in previous strategy, and that if New Zealand is to improve economic performance, 'we must be able to ensure that the electricity and fuel needs of a growing society can be and are met.' ${ }^{289}$ Clearly security of supply was prioritised in National's new approach to energy security. Security of supply was the thrust of its argument in response to the Clark Government's energy policy. Thus the Key National Government perceives energy security in a traditional sense as the secure and reliable supply of energy. Its logical energy policy response is to develop these resources, which sits comfortably with the Government's goal of economic growth.

The wake of the Global Financial Crisis was a favourable condition for the Key National Government's policy response to energy security, centred in concerns for economic growth and security of supply. The financial crisis that occurred in early 2008, which led to the global economic recession, most certainly had a political toll on climate change policy. Internationally, the financial crisis heightened fears of the cost emissions would place on already strained economies. ${ }^{290}$ For New Zealand, economic concerns were high on the political agenda and were only made more important by the economic recession. Upon his election Prime Minister John Key unveiled his Cabinet and pledged to 'focus on boosting economic growth and tackling the global financial crisis in a country suffering recession.' ${ }^{291}$ The politicisation of energy security risks in energy policy has taken a backseat to the greater political focus on managing the crisis.

\footnotetext{
289 Brownlee, "Government Consulting on Energy Policy."

${ }^{290}$ Muriel Newman, "Comment: Climate Change Review Echoes World Trend," The National

Business Review, http://www.nbr.co.nz/article/comment-climate-change-review-echoes-worldtrend-37859.

${ }^{291}$ AFP, "New Zealand's Pm-Elect Unveils Cabinet with Focus on Economy," www.channelnewsasia.com, http://www.channelnewsasia.com/stories/afp_asiapacific/view/390354/1/.html.
} 
Immediate economic concerns weigh heavily on the current government's political agenda as well as the voting public. The energy policy response to these concerns has been to supersede the Clark Government's rhetorical politicisation of long-term energy security risks. Given the shock of the crisis to the national economy, it is not surprising that the Key National Government would be successful in pushing through its pre-existing campaign agendas: the unrelenting focus on security of supply and retracting the Labour Government's robust domestic climate change policy.

As discussed in Chapter Four, energy security also disappeared from key foreign policy documents following the 2008 election. The National Government's development of its distinct rhetoric is consistent with its economic approach to energy security, and its markedly different approach to climate change policy. Helen Clark's Labour Government considered climate change as an opportunity to demonstrate to other nations that it was possible to implement emissions reductions policy without imposing high costs on the economy. ${ }^{292}$ The Key Government aims to promote international efforts and rules that 'accommodate New Zealand's circumstances and interests, and are affordable.'293 This sentiment was reiterated by Prime Minister John Key when he stated 'We campaigned solidly on taking a balanced approach to climate change, balancing our environmental responsibilities with our economic opportunities,' and furthermore that 'We don't want to be a global leader in climate change.' ${ }^{294}$ These comments were echoed by Hon Dr Nick Smith, who argued that the goals of the Labour Government to lead the world on climate change did more harm than good to New Zealand's international reputation, and said 'It is just unrealistic to continue to pretend we are, or can be, world leaders in reducing emissions.'295 The Key National Government essentially re-focused energy security's place in

\footnotetext{
292 Parker, "Interview."

${ }^{293}$ Ministry of Foreign Affairs and Trade, "Statement of Intent 2010 - 2013." p. 23

294 Dennis Shanahan, "Kiwi Pm Wants Trans-Tasman Consensus on Emissions Trading," The Australian National Affairs, http://www.theaustralian.com.au/national-affairs/climate/kiwipm-wants-ets-consensus/story-e6frg6xf-1111119013985.

${ }^{295}$ Smith, "Nick Smith: Climate Change and Business Conference."
} 
strategy to the Ministry of Economic Development alone. The MED states that the current draft strategies are not action plans but sharply-focused statements of government energy policy, and that '[b]y focusing on near-term actions, the 2007 strategies - and the NZEECS in particular - quickly became out of date.'296 These near-term actions, evidently, are those that can stimulate economic growth in the wake of a global economic recession.

The Key Government's draft NZES 2010 (and the finalised NZES 2011) gave a clear signal that the energy market would respond to fundamentals of this market, rather than the government responding to the risks of the market through energy policy. The draft NZES 2010 stated that New Zealand has an abundance of resources (including less well known petroleum and mineral reserves) and that 'it is a priority of this government to develop those resources,'297 in the interest of stimulating the economy. The finalised NZES 2011 did not dramatically change this tack. Thus the response to the rising international demand for energy is to increase the availability of New Zealand's resources for export. Solid Energy epitomised this view, stating that '[i]n a world increasingly starved for available, affordable energy and other commodities many countries are threatened - but our indigenous natural resources make us one of the world's richest nations.' 298 The development of these resources therefore, would take opportunity of the international demand for resources rather than being an area of concern.

The Key National Government's rhetorical politicisation of energy security resonated with its constituency who had felt the NZES 2007 compromised its industries. Energy companies need favourable political, legislative and investment climates in order to fund and continue their projects, hinging on the

\footnotetext{
${ }^{296}$ Ministry of Economic Development, "Questions and Answers," www.med.govt.nz, http://www.med.govt.nz/templates/Page__44120.aspx.

297 - - - , "Draft New Zealand Energy Strategy and the Draft New Zealand Energy Efficiency and Conservation Strategy." p. 1

298 Solid Energy New Zealand Limited, "Our Natural Resources," coalnz.com, http://www.coalnz.com/index.cfm/1,134,0,0,html/About-Solid-Energy.
} 
certainty that they have a future place in the market. TrustPower argued that the energy security goals under the NZES 2007 were unlikely to be met, because, if a 'promise' of carbon pricing post 2012 was made 'fossil fuelled generation will be concerned that their generation will be displaced [...] and renewable generation will have the risk of not receiving future income if carbon pricing is does not eventuate.' 299 For example, the Petroleum Exploration and Production Association of New Zealand (PEPANZ) considered that the NZES 2007's focus on renewable resources in electricity generation, and phasing out of nonrenewable resources from base-load generation, would pose a number of risks to the gas market. They supported this argument by stating that gas-fired generation underpins renewable generation and that the key issue of energy security [is] if New Zealand places too much reliance on renewable energy.'300 The issue of energy security for PEPANZ is really about the certainty of its position in the market. The Government's policies would '[provide] explorers (i.e. PEPANZ's members) with no degree of certainty that there will be a sustained development of the New Zealand gas market [...].'301 Furthermore, that growth in the gas industry would be constrained by impeded investment and development.

Energy security in the NZES 2011 is a clear policy focus in itself, rather than the embodiment of risks to the energy system in the NZES 2007. As argued in Chapter Four, the focus on security of supply and development of all energy resources means that the Key Government's approach to energy security is characterised by a 'security alone' mind-set. By projecting this view, the NZES 2011 clearly allayed concerns in the energy market that some energy participant's future position in that market would be compromised by the NZES 2007. For instance, in its submission to the NZES 2010, PEPANZ stated that it 'supports the

\footnotetext{
299 TrustPower, "Combined Submission Draft New Zealand Energy Strategy to 2050, Measures to Reduce Greenhouse Gas Emissions Post 2012, Transitional Measures, Draft National Energy Efficiency and Conservationa Strategy," (30 March 2007).

300 Petroleum Exploration and Production Association of New Zealand, "Pepanz Energy Strategy Submission 2007," ed. John Pfahlert (Wellington30 March 2007).

301 Ibid.
} 
priority recognition given in the strategy to the concept of energy security, a glaring omission from the 2007 strategy.'302 The Key National Government is giving a clear signal to the energy market that it does not intend to intervene in the future of New Zealand's energy system. This is why it does not invoke risks to the system, as to invoke risks would mean that the Government would have to address these risks. This response is in line with the views espoused in the NZES 2011 (as argued in Chapter Four): market uncertainty does not pose risks great enough to prioritise a strong policy response to climate change. The market, ultimately, will respond to the challenges of climate change and energy security.

A favourable condition for the Key National Government (and less ideal for the Clark Government) is a low articulation of energy issues in terms of risk. While the public has been concerned about the price of energy, discourse does not naturally invoke energy security risks. Professor Ralph Sims identified low public awareness of energy issues as a key problem in New Zealand. He added that there will be 'no change in policy unless [there is] a change in public attitude.' ${ }^{303}$ As highlighted in the Introduction, Nobuo Tanaka, Executive Director the IEA, argues that the world is facing unprecedented uncertainty in the energy market. This is not just uncertainty in the market itself, but crucially in how governments will respond to the complexity of energy issues today in their energy policy. This uncertainty was included in the Clark Government's rhetorical politicisation of energy security, but not in the current NZES 2011. The Clark Government's argument may have found resonance with a particular constituency. The Key Government's energy policy however, shows clearly that articulating energy security in terms of risk has been limited by the opposing discourse of certainty and reliance in the free-market. This still leaves the longterm risks of energy security and climate change in the eyes of opposition to the draft NZES 2010, insufficiently responded to in policy (even if not publicly articulated in terms of risk.)

\footnotetext{
$302---$, "Submission: Petroleum Exploration and Production Association of New Zealand (Pepanz)," ed. John Pfhalert (10 August 2010). p. 1

303 Sims, "Interview."
} 
The Key Government faced resistance to its new energy policy stance and response to energy security. The Green Party gave rather forthright opinions on the draft NZES 2010, stating that 'We cannot end our addiction to fossil fuels, lower emissions or achieve energy security by digging up more of what we are trying to use less of.' ${ }^{304}$ This is an effort to prioritise the concept of energy security and climate change, over energy security that emphasises security of supply. On 16 December 2008, in reference to the Electricity (Renewable Preference) Repeal Bill, the Green Party co-leader Jeanette Fitzsimons argued that the Minister for Energy, Hon Gerry Brownlee, 'says that we need to build more fossil-fuelled plants for security of supply,' and in retort argued that 'if we want security of supply we need a diversity of renewable sources.' ${ }^{305}$ She then stated that focusing on security of supply (meaning that supply can meet demand) and building more supply, is unreliable and expensive, in comparison to demandside measures of efficiency and home insulation. Finally, after highlighting both supply and demand-side facets of energy policy, she states that if Gerry Brownlee wants energy security he needs to focus a lot more on the demand side than New Zealand ever has.' ${ }^{306}$ Clearly Fitzsimons highlights that the focus on security of supply alone will not achieve what the Green Party regard as energy security.

In opposition to the draft NZES 2010, Labour energy spokesman Charles Chauvel argued that National has a lack of oversight in energy policy, that 'according to the Electricity Commission, energy security is deteriorating [...] and prices keep escalating.' In particular, its hands-off approach has 'been exposed' from a poorly implemented home insulation scheme. ${ }^{307}$ Chauvel's comments show that energy

\footnotetext{
304 Green Party, "Joint Submission on the Energy Strategy (Nzes) and the Energy Efficiency and Conservation Strategy (Nzeecs)," ed. Metiria Turei and Dr. Kennedy Graham (Wellington2 September 2010). p. 3

305 Jeanette Fitzsimons, "Electricity (Renewable Preference) Repeal Bill - First Reading, Second Reading, in Committee, Third Reading," parliament.nz, http://www.parliament.nz/enNZ/PB/Debates/Debates/Speeches/0/7/d/49HansS_20081217_00001201-Fitzsimons-JeanetteElectricity-Renewable.htm. 
security is considered as something that can only be addressed with a strong government policy response, and that there is no security in leaving the market to address long-term risks to the energy system. Chauvel's comments also resonate with the concerns of key stakeholders who have expressed opposition to the draft NZES 2010. The Environment and Community Development Centre argued that 'generally, the draft NZES and NZEECS put a heavy reliance on markets to produce solutions, even where this approach is not appropriate or workable (e.g. energy security).' ${ }^{308}$ The long-term energy security risks are also politicised by this group, in order to argue that these issues need to be addressed in the finalised NZES 2011. As Chapter Two argues, to highlight risks or threats to energy security is to imply that these risks require governance, therefore, should be prioritised in policy or political debate. The Wellington City Council argued that 'most targets refer to 2015 and given the risks with energy security and climate change, the Council believes New Zealand's energy strategy needs to have a long-term approach.' ${ }^{309}$ It also argues that the strategy should find pathways for 'New Zealand to reduce fossil fuel dependency in order to manage increasing fossil-fuel energy costs, energy security risks and carbon costs.' 310 Local Government New Zealand states that 'A key difference between this draft NZES and the current strategy [NZES 2007] is its more candid recognition of impending issues in the longer-term, particularly around the future use of oil and fossil fuels.' 311 Evidently this reflects how Labour energy spokesperson Charles Chauvel refers to energy security and energy strategy, as well as the NZES 2007.

\footnotetext{
308 Environment and Community Development Committee, "Consultation Reponse to Draft New Zealand Energy Strategy and New Zealand Energy Efficiency and Conservation Strategy," ed. Jake Roos (Kapiti Coast District2 September 2010). ${ }^{309}$ Wellington City Council, "Submission to the Draft New Zealand Energy Strategy," ed. Strategy and Policy Committee (Wellington, 2 September 2010).

310 Ibid. p. 3

${ }^{311}$ Local Government New Zealand, "Submission to the Ministry of Economic Development on the Draft NZ Energy Strategy, and the Draft NZ Energy Efficiency and Conservation Strategy 2010," (Wellington, 2 September 2010); Wellington City Council, "Submission to the Draft New Zealand Energy Strategy." p. 3; Susanne Becken, "Submission to the New Zealand Energy Strategy," ed. Lincoln University (Christchurch31 August 2010). p. 2
} 
This resistance coincided with a marked change between the draft NZES, released in 2010, and the finalised NZES 2011. First, in the draft NZES 2010, the Key Government did use an energy security argument to support the development of renewable, petroleum and mineral resources. In regards to the latter however, the argument was less explicit. For instance, the draft NZES 2010 stated that 'boosted' energy security is a benefit of developing a mix of renewable energy resources, alongside other benefits of creating jobs, and increasing the availability of energy to assist economic growth. ${ }^{312}$ When it came however to oil and gas finds, it stated that ' $[t]$ he effect of future gas or oil finds on New Zealand energy security is difficult to forecast and will depend on the size of discoveries $[\ldots]^{\prime 313}$ Resistance to the exploration by foreign companies in New Zealand offshore basins was vocal and tense: public opposition and protests by Greenpeace in April through to July of 2011 were prevalent in mainstream media, and a hot topic of debate. ${ }^{314}$ The Government however, did not change its stance to promote oil and gas exploration in policy.

The marked change in language appeared in the NZES 2011 released recently in August. The rhetorical politicisation of energy security in the NZES 2011, more subtle in the draft NZES 2010, included a new emphasis on global energy security. As outlined in Chapter Four, the NZES 2011 states that New Zealand can contribute to global energy security through the development of petroleum and mineral resources. ${ }^{315}$ It states also how New Zealand was commended for this policy measure by the International Energy Agency. Furthermore, that this is part of New Zealand's 'global role.' 316 This language and argument was simply

\footnotetext{
312 Ministry of Economic Development, "Draft New Zealand Energy Strategy and the Draft New Zealand Energy Efficiency and Conservation Strategy." p. 11

313 Ibid. p. 14

${ }^{314}$ Lois Cairns, "Greenpeace: Oil Exploration's Political Hot Potato," nzherald.co.nz, http://www.stuff.co.nz/national/politics/5297054/Greenpeace-Oil-explorations-political-hotpotato.; Newstalk ZB, "Greenpeace Not Backing Down," newstalkzb.co.nz, http://www.newstalkzb.co.nz/newsdetail1.asp?storyID=194414.

315 Ministry of Economic Development, "New Zealand Energy Strategy 2011 - 2021: Developing Our Energy Potential." p. 3

316 Ministry of Economic Development, "New Zealand Energy Strategy 2011 - 2021: Developing Our Energy Potential." p. 3
} 
not included in the draft NZES 2010. In addition, after the release of the 2011, Hon Hekia Parata stated that 'We [...] can't ignore the major economic opportunity that continuing global oil demand could provide New Zealand.'317 In light of this political rhetoric, New Zealand's contribution to global energy security is clearly an economic benefit and marks the Key Government's views of rising international energy demand; an economic opportunity. Thus the rhetorical politicisation of global energy security serves to bolster this argument, particularly against the tension this could have with New Zealand's climate change commitments. This is a distinct argument to the Clark Labour Government, who prioritised the goal for New Zealand to be an international leader on climate change (and shaped its presentation of energy security accordingly). The Key Government have responded to this argument, counteracting it with a redefinition of New Zealand's global role: to contribute to global energy security. Like the Clark Government, energy security is shaped to convince key stakeholders and opposition of the merits of this policy response.

\section{Conclusion}

The two rhetorical politicisations of energy security have been used to argue for two different energy strategies. This occurred because of three key factors brought to light in this chapter. First, the formative stage of energy policy in New Zealand. Second, divisive constituency views of energy security. Third, economic and political conditions that favoured as well as hindered the development of each Government's energy policy. The Clark Government pushed its perspective on energy security and climate change when economic and social conditions were in its favour. When the Key Government came to power it brought its prioritisation of economic growth and its different approach to climate change policy. The impacts of the Global Financial Crisis conveniently suited this agenda. The Key Government's argument for energy security, framed by stimulating

\footnotetext{
317 Jared Smith, "Trundle Welcomes Energy Strategy from Government," taranakidailynews.co.nz, http://www.stuff.co.nz/taranaki-daily-news/business/5563940/Trundle-welcomes-energystrategy-from-government.
} 
economic growth, resonated with the crisis. In addition, the Clark and Key Governments' distinct energy policies are also shaped by two competing perspectives on energy security risks that are debated among key market actors and stakeholders in energy policy. The two competing sides frame energy security risks in support of its differing views on climate change and the role of government in the energy sector. As with the Key and Clark Governments respectively, one side places emphasis on security of supply alone. It raises concerns for economic growth and the certainty of business-as-usual in the energy market, which would be affected by strong climate change policies. The other side places emphasis on the long-term risks associated to both energy security and climate change. The ability of the market to address these concerns without government leadership and action in policy is questioned. These divisive constituency views have resonated with each Government's rhetorical politicisation of energy security.

The Government in power, with support from the constituency and favourable economic and political conditions, has meant two very different approaches to energy security have manifested in energy policy. The less ideal conditions have also shaped the distinct politicisations of energy security. Government must argue its case convincingly, in which its interpretation of energy security has had a prominent role. Thus different energy security risks are contested, and highly politicised in New Zealand energy politics. Current energy strategy is now heading in a divergent direction from the former Clark Government. Politicisation has thus lead to inchoate political discourse on energy security. Whether politicisation has helped or hindered the development of energy policy in New Zealand is left to be decided, and the task of discussion in the final chapter. 


\section{Chapter Six \\ Conclusion}

Energy security is a highly politicised and contested concept in New Zealand politics. Two distinct rhetorical politicisations of energy security have been used to legitimise the Clark and Key Government's respective energy policies. The Clark Government's rhetorical politicisation of energy security prioritises longterm risks to the energy system. This aimed to legitimise more robust climate change policy. In comparison, the Key Government uses politicisation to bring security of energy supply to the forefront of its political agenda. This is to support its policy initiative to develop renewable, petroleum and mineral resources. While politicisation has led to greater salience of energy security in New Zealand's energy policy overall, clearly it has coincided with divergence in energy policy. A final question remains: has politicisation of energy security helped or hindered the development of energy policy in New Zealand? This chapter will address this question in two sections. The first section will provide a critical overview of the findings from the previous chapters. The second section evaluates the effects politicisation has had on New Zealand energy policy development.

The discussion in these sections will suggest that the Clark Government's politicisation of energy security helped stir a necessary debate on New Zealand's energy system and future. It has brought energy security onto the political agenda. Energy security however, remains a contested concept as a result of politicisation. Polarised views have led to flip-flopping rhetoric in energy policy between the Key and Clark Governments. First, this is problematic because it has led to political uncertainty for the energy market. Second, the current marketorientated concept of energy security means that policy will follow energy market trends. Response to energy security is market-driven therefore, developing New Zealand's petroleum and mineral resources responds to 
increasing international energy demand. This rhetorical politicisation of energy security does not substantially hinder policy towards New Zealand's domestic energy system change. The current energy security rhetoric does however, make domestic and international climate change policy appear less coherent. Overall the politicisation of energy security has helped contribute to what will hopefully be, a rising debate on New Zealand energy policy. The debate is needed, it is continuing, and this suggests that energy security's place in policy will not go without being questioned.

\section{Overview}

The thesis addressed three questions: has energy security been politicised in New Zealand politics? If so, how has it been politicised? And finally, has this hindered of helped the development of energy policy in New Zealand? The politicisation of energy security in New Zealand has followed international trends in energy discourse. Chapter One highlighted that energy security has become more important in international debate. The relationship between energy security risks, well-functioning economies and climate change has been brought to the attention of both scholars and policymakers. It is also debated by scholars and policymakers, who have argued that the concept can no longer be understood as simply the secure, reliable and affordable supply of energy. The concept of energy security must be re-conceptualised to include new environmental and social concerns. Likewise it has been brought to the attention of policymakers in New Zealand. It is the subject of debate between politicians, bureaucrats and key stakeholders in energy policy.

The Clark Labour Government's rhetorical politicisation of energy security brought the risks of New Zealand's energy system onto the political agenda. This occurred at the same time as a strong policy focus on addressing climate change. Through a strategy of politicisation the Clark Government forged a whole-ofgovernment approach to energy security and climate change. The Government 
institutionalised an integrated approach to both issues in the mandates of government departments. The appointment of David Parker as Minister of Energy and Minister Responsible for Climate Change Issues further deepened this institutionalisation of energy security and climate change. These moves placed climate change at the heart of energy and economic policy development, the MED, and linked this policy approach in the mandates of the Ministry of Foreign Affairs and Trade, Ministry for the Environment and the Ministry of Transport. This mimics examples of politicisation overseas that were cited in Chapter One. First, energy was placed at the heart of climate change agenda at G8 in 2005. In the U.S. Hillary Clinton established the International Energy Affairs at the State Department to demonstrate the importance of energy security to U.S. Foreign Policy. President Obama also highlighted the dire need for the US to reduce its oil dependency stating that 'America will not be held hostage to dwindling resources, hostile regimes and a warming planet [... $]^{1318}$ And finally, in his remarks to the Climate Change Conference in Cancun last year, United Nations Secretary General Ban Ki-Moon stated that 'We will never assure energy security - or international security - without climate security.' 319 The Clark Government's politicisation of energy security risks supported the institutionalisation of the climate change, energy and economic policy-formation nexus in New Zealand. Given that the international examples are recent, this nexus is still relevant.

The Copenhagen School's Theory of Securitisation was used to understand the dynamics behind the Clark Government's politicisation of energy security. As Chapter Two argued, Securitisation Theory understands that security is subjective and socially-constructed. This suited an analysis of energy security in New Zealand politics for two key reasons. First, scholars and policy-makers argue that energy security is a highly subjective and context-dependent concept. Second, there was evidence of debate and disagreement between politicians on

\footnotetext{
318 Obama, "Obama Orders Push to Cleaner, More Efficient Cars."

${ }^{319}$ Ki-moon, "Remarks to Climate Change Conference (Unfccc Cop16 High-Level Segment) - as Delievered."
} 
energy security. Securitisation Theory could also help understand the dynamics (and politics) behind the energy security rhetoric in New Zealand. Chapter Two highlighted that a politicisation is when an actor argues that an issue is salient enough (often through security rhetoric of risk or threat) to be elevated to political debate and governed within politics. This is different to a securitisation, when a security argument convinces audience that an issue is urgent and threatening enough to require emergency action above politics. The appeal of security arguments is not lost in politicisations. Threats and risks to national well-being are used to elevate energy security and climate change issues. This often results in these issues being governed within politics, rather than leading to securitisation. Furthermore, actors will draw on existing narratives, discourses, or contextual factors, in order to form an argument that will be convincing and more successful with an audience.

Thus in Chapter Three, Securitisation Theory showed how a strategy of politicisation was used to support the Clark Government's climate change policy. Energy security embodied risks in the international and domestic energy markets. A security argument was used to legitimise its initiative for stronger leadership in the energy sector. This leadership involved clarifying New Zealand's energy future in support of its climate change objectives. The Clark Government sought to synthesise environmental and economic concerns through energy security. This informed and helped forge the whole-of-government approach to climate change. The politicisation of energy security played a central role in institutionalising common perceptions of risks to the energy system (and how they relate to climate change) through relevant departments. For instance, energy security became part of a strategic role in the Ministry of Foreign Affairs and Trade; seen as something that was integral to addressing both economic development and climate change concerns.

It was understood from the analysis in Chapter Two that politicisation is an open-ended process that can have different political and policy impacts. 
Applying Securitisation Theory to an analysis of the Key National Government confirmed this, insofar as its rhetorical politicisation prioritised a different concept of energy security in policy. Chapter Four showed that the Key Government adopted the energy security label, but shaped a different rhetorical argument in favour of its policy to develop all of New Zealand's energy resources. Politicisation of energy security led to a dramatic shift between the Clark and Key Government's energy policies. The Key Government did not use a security argument to support its initiatives (by highlighting risks to the energy system), nor was uncertainty in the energy market (to deliver energy resources) conveyed through the concept. Nevertheless they used a strategy of politicisation to elevate security of supply on the political agenda. This also used rhetoric of well-being and economic growth to support its policy focus on developing renewable, petroleum and mineral resources. Chapter Two showed how energy security can mean different things to different actors. In the case studies, even though the same term is used energy security means something quite different to the Clark and Key Governments respectively. Thus politicisation has been used to prioritise two different concepts of energy security in support of their distinct policy initiatives.

The Clark Government's rhetorical politicisation of energy security supported its focus on energy system change. This aimed to help the country meet a domestic emissions reduction target and fulfil its international climate change commitments. The Key National Government's rhetorical politicisation argues for the benefits to domestic and global energy security that a policy focus on mineral and petroleum resource development (as well as renewables) would bring. Again, similar trends can be seen in the international debate discussed in Chapter Two. In particular, politicisation of energy security can aim to help prompt change in the energy system for climate change policy. It can also stall this type of change. The rhetoric and intention of the Clark Labour Government was for robust energy system change. 
As Chapter Five discussed, economic and political conditions were favourable enough for the Clark Government to push its climate change policy. Securitisation Theory helped show how its rhetorical politicisation of energy security drew on resonating conditions to support its policy initiatives. These conditions included risks to the energy system (in electricity generation particularly) that had arisen in early 2000s and that its concept of energy security embodied in the NZES 2007. The public were enjoying relative economic prosperity and were open to thinking about climate change issues. Yet given the strong free-market culture in the energy sector, and strong public resistance to its previous climate change policy initiatives, the Clark Government had to structure a convincing argument to win over the opposition. Securitisation understands that a security argument has tactical appeal because they can be powerful when a threat is invoked and legitimises a policy response. Highlighting energy security risks and demonstrating how they could be addressed through climate change policy was at the heart of the Clark Government's strategy. Energy security therefore, embodied a tactical move to further push to for energy system change through policy initiatives like the 90 percent renewables energy target.

The Key National Government's rhetorical politicisation of energy security is in part, a counter-argument to robust energy system change driven by climate change policy. Securitisation Theory enabled an understanding of what dynamics lay behind this move. Politicisation of energy security was used to prioritise a very different sort of change to the Clark Labour Government: the development of New Zealand's fossil fuel resources, including oil, gas and coal. Concern for climate change was trumped by the election of the Key National Government and heightened public concern for the global financial crisis. The Key Government's politicisation of energy security resonated with these conditions. First, the concept was informed by a more cautious approach to climate change negotiations and policy. Comparatively to the Clark Labour Government, the Key Government argued that they aimed to protect New Zealand's economic interests by not pushing strong emissions policy prematurely. Energy security 
was retracted from a whole-of-government approach to energy security risks and climate change, and institutionally centralised to the purview of the Ministry of Economic Development. The urgency rhetoric of climate change was not linked to energy security. The Clark Labour Government did this by framing risks to the energy system through an economic and environmental lens. The Key National Government's retracted concept was primarily viewed through an economic lens.

The Key National Government reinforced its argument for developing all resources by drawing on relevant international conditions of the energy market. Politicisation of energy security helped the development of its policy stance. A common theme in the international energy market cited in Chapter One, Three and Four, is that there is an increasing world demand for energy. There are particular concerns for whether the supply of petroleum can keep up with this rising demand as new easy-to-tap supplies begin to dwindle. More expensive and difficult exploitation of resources is needed. The Key Government politicised the issue of global energy security in the NZES 2011. Securitisation theory revealed that this was not just a case of New Zealand fulfilling its international role as a member of the IEA. First, in the NZES 2011 global energy security was synthesised with the domestic economic benefit of developing petroleum and mineral resources. Second, this rhetoric resonated with the constituency group who had initially criticised the NZES 2007. Energy market actors in gas, coal or oil exploration, expressed concerns for the future of their industries under the more robust climate change policy of the NZES 2007. This was targeted at the strategy's clear focus on renewable resources. They also expressed concern for how this policy focus could threaten energy security. The NZES 2011 mirrors their concerns with its emphasis on security of supply and explicit prioritisation of developing all resources to include petroleum and minerals.

The Key Government also faced resistance to its policy. Securitisation Theory was able to reveal this third dynamic that shaped the Key Government's rhetorical politicisation in defence of its policy initiatives. Chapter Five demonstrated that 
energy security is a contested issue between key stakeholders and market participants of energy policy. The Clark Government also had a constituency group who used similar energy security rhetoric to criticise the draft NZES 2010. The group argued for the need to address climate change by prioritising longterm risks to the energy system. The Key Government also faced particular resistance to its emphasis on developing New Zealand's petroleum and mineral reserves. Very public protests by Greenpeace erupted in New Zealand's East Cape, where oil exploration was being carried out by the Brazilian company Petrobras. Global energy security was a new feature in the NZES 2011 not seen in the draft NZES 2010. In the NZES 2011 there was a heightened awareness for both energy security and climate change concerns. The rhetorical politicisation in the NZES 2011 elevated the concept of global energy security (in which New Zealand should contribute to through the development of petroleum and mineral resources) with that of domestic commitments to respond to climate change. Politicisation has clearly led to the salience of energy security rising on both Government's agendas. Two different rhetorical politicisations of energy security however, show clear divergence in energy policy.

The Copenhagen School does not comprehensively consider the variety of outcomes politicisation can have. Analysis of energy security in New Zealand politics reveals that politicisation is quite complex. The thesis shows that the politicisation of energy security in New Zealand has clearly resulted in a patchwork of different institutional and rhetorical moves by the Clark and Key Governments. Politicisation of energy security has aided the acceptance of their respective policies by giving clear signals to their constituency group and defending their strategies against criticism. Assessing whether politicisation has been good or bad towards the overall development of energy policy in New Zealand is a more contentious, and a speculative issue for analysis. It also reveals the limitations of Securitisation Theory analysis, particularly in regards to the impacts of politicisation. This is because of the Copenhagen School's original mandate: it aimed to provide a framework to distinguish a security issue from 
the widening of the security agenda to a broader range of issues (including economic, environmental and societal issues). ${ }^{320}$ As Walter B. Galliue, cited by Barry Buzan in People, States and Fear, states, '[w]ithin the International Relations' sub-discipline security studies, security is regarded as being an "essentially contested concept".' 321 Buzan et al. sought to address the dynamics and difficulties of attaching the word security onto a greater variety of issues seen in recent times. ${ }^{322}$ Their framework did broaden analysis of security from traditional military-political lens to include non-traditional security issues. Their purpose however, was quite specific. By providing an explanation of the processes and dynamics behind securitisations they aimed to clarify what a security issue is. 323 Thus their theory does not comprehensively address the effects of politicisations, particularly in relation to whether politicisation is a good or bad thing.

There is perhaps no easy answer then, for the third question of this thesis: has politicisation of energy security helped or hindered the development of energy policy in New Zealand? First, what has happened in New Zealand is a far cry from a full securitisation. Based on the Copenhagen School this is a positive because security is negative, as it can be a catalyst for panic politics and legitimises special state power. ${ }^{324}$ Energy security is addressed within politics and remains subject to debate in New Zealand. Securitisation Theory has revealed the processes and dynamics behind the debate on energy security. Based on the theory, energy security has a legitimising role in the development of energy policy. The incumbent Government demonstrates that its policy continues

\footnotetext{
320 See Colin Innes \& Simon Rushton, "Hiv, Aids and Security: Where Are We Now?," International Affairs 86, no. 1 (January 2010).; Roxanna Sjöstedt, "Exploring the Construction of Threats: The Securitization of Hiv/Aids in Russia," Security Dialogue 39, no. 1 (March 2008).; Ki-moon, "Remarks to Climate Change Conference (Unfccc Cop16 High-Level Segment) - as Delievered." Ban Ki-Moon stated 'We will never assure energy security - or international security - without climate security.'; Brown, Hammill, and McLeman, "Climate Change as the 'New' Security Threat: Implications for Africa." Food security, p. 1146

${ }^{321}$ Rita Floyd, "The Environmental Security Debate and Its Significance for Climate Change " The International Spectator, 43, no. 3 (2008). p. 51

${ }^{322}$ Buzan, Waever, and Wilde, Security: A New Framework for Analysis. p. 21

323 Ibid. p. 1

${ }^{324}$ Ibid. p. 21
} 
to address energy security, and its rhetoric defends new policy initiatives that may come under criticism. The analysis across Chapters Three, Four and Five showed that both Governments took a hard-line on what they thought was the best way to approach the challenges of economic growth, climate change and energy security. Both Governments faced resistance but neither dramatically changed their tack. Instead, they supported their respective policy stances by rhetorical politicisation of energy security. They were not completely successful in arguing their cases, and debate remains. The empirical analysis therefore demonstrates that politicisation of energy security in New Zealand has not lead to resolution on the issue. The Copenhagen School ask whether it is good or bad to securitise a certain issue, and place it in the realm of panic politics rather than normal politics. ${ }^{325}$ But has politicisation, despite a lack of resolution in debate, hindered or helped over-all energy policy formation?

\section{Discussion}

Politicisation has stirred a necessary debate in New Zealand's energy politics. As discussed in Chapters One and Two, in international politics there has been a heightened concern for energy security and climate change. Both have been elevated to the top of political agendas around the world. These issues are complex and present acute challenges for policy-makers. As noted in Chapter One, Nobuo Tanaka, Executive Director of the IEA, argues that the world is facing unprecedented uncertainty in the energy market. This is not just uncertainty in the market itself, but crucially in how governments will respond to the complexity of energy issues today in their energy policy.

Given the salience of energy security in international politics and debate, New Zealand needed to bring these issues to debate at the domestic level. As highlighted in Chapter One scholars and policy-makers have argued that a simple definition of energy security is insufficient to meet today's challenges. The 
concept itself has to change. This is crucial to the development of a policyresponse to the fundamental challenges that climate change and the international energy market presents. New Zealand is not immune to risks that an uncertain energy future may present. Events, shocks or disruptions that highlight the vulnerability of the energy system do invoke major policy response. Examples of this include the wake of the 1973/74 and 1979 Arab Oil disruptions, or the major droughts of early 2000s that placed pressure on the hydro-dams and caused electricity prices to rise. Policy-makers and academics are aware that, in these events, the public will turn to the government to address threats when they arise. For instance, Shell International forecasts that the longer the delay in climate policy action, the more likely shocks become. 326 These shocks are primarily price shocks from knee-jerk policy responses to major events, such as the physical effects of severe storms or floods. ${ }^{327}$ If the current rate of greenhouse gases emitted into the atmosphere from the consumption of fossil fuels continues, the world will face unprecedented challenges from a dramatically altered climate system by $2100 .{ }^{328}$ Understanding and debating energy security risks is the first step to developing a policy response. It cannot be a standalone issue, given that today, energy is inexorably linked with addressing climate change.

The concept of energy security in New Zealand politics currently has a traditional focus on a secure and reliable supply of energy. Chapter Four showed that a strategy of politicisation was used in NZES 2011 to elevate security of supply concerns. Security of supply is traditionally at the core of energy policy. ${ }^{329}$

\footnotetext{
326 Shell International BV, "Shell Energy Scenarios to 2050: An Era of Volatile Transitions," in Shell Scenarios to 2050: Signals and Signposts (The Hague: Shell Internation BV, 2011). p. 16 - 17 327 Shell International BV, "Shell Energy Scenarios to 2050: An Era of Volatile Transitions," in Shell Scenarios to 2050: Signals and Signposts (The Hague: Shell Internation BV, 2011). p. 16 - 17 328 See IPCC, "Climate Change 2007: The Physical Science Basis," in IPCC Fourth Assessment Report (AR4) (IPCC, 2007).; Hansen et al., "Dangerous Human-Made Interference with Climate: A Giss Modele Study," Atmospheris Chemistry and Physics 7(2007).

329 Sauter, "E.U. Energy Security from an Agenda-Setting Perspective - Implications for E.U. Climate Change Policy?". p. 109; Helm, "Energy Policy: Security of Supply, Sustainability and Competition." P. 175 ; Sauter, "E.U. Energy Security from an Agenda-Setting Perspective Implications for E.U. Climate Change Policy?". p. 109;LaCasse and Plourde, "On the Renewal of Concern for the Security of Oil Supply." P. 1 Cited in Bahgat, "Europe's Energy Security: Challenges and Opportunities." p. 965
} 
This component of energy security has become inherent to the current model and is common as a strategy today insofar as management of supply is the dominant focus of policy, rather than management of demand. ${ }^{330}$ This stance was hardened after the controversies over the first draft strategy, and finalisation of the NZES 2011. The inclusion of global energy security rhetoric in the latest strategy has bolstered the argument to supersede climate change concerns for the continued development and consumption of fossil fuels.

This is not however, an anomaly in the world but in step with international trends. The depth of the financial crisis has led to political flip-flops elsewhere and intensified lobbyist pressure to respond to the crisis by developing indigenous resources. A report by the petroleum company Shell International gives the example of energy policy direction in the U.S. President Obama had initially decided to open more of the Outer Continental Shelf (OCS) for drilling (prior to the moratorium on development after the Deepwater Horizon Spill in the Gulf of Mexico.) This was to increase energy supply security and reduce imports from foreign states, and coincided with a stalling of climate legislation due to the difficult political environment left by the intense economic slowdown. ${ }^{331}$ In this instance energy security rhetoric has hindered climate change policy development and therefore, energy system change. The report by Shell International states that,

The recession has [...] provided governments, anxious to weather the downturn, with opportunities to take regulatory measures. Concerns about employment, debt, economic competitiveness, energy security and climate change are now being used to justify this. These measures are accelerating or delaying energy system change, depending on the political or economic circumstances. ${ }^{332}$

\footnotetext{
${ }^{330}$ Mely Caballero-Anthony, "The Way Forward for Energy Security." p. 1

331 Shell International BV, "Shell Energy Scenarios to 2050: An Era of Volatile Transitions," in Shell Scenarios to 2050: Signals and Signposts (The Hague: Shell Internation BV, 2011). p. 65

332 Ibid. p. 23
} 
Reflecting on this, the Clark Government's rhetorical politicisation was sufficient enough to influence current energy strategy. There are still remnants of the Clark Government's energy security rhetoric and climate change policy in place. First, the criticism of the draft NZES 2010 highlighted issues that had been politicised in Labour's NZES 2007. The patterns in energy security debate (as shown in Chapters Three, Four and Five) are sufficient to suggest an influential interaction between the Clark Labour Government and its constituency. This was enough to build rhetorical resistance to the Key National Government's politicisation.

Second, the draft NZES 2010 did not recognise energy security and climate change as challenges. Comparatively the finalised version, the NZES 2011, did. While this was more often expressed in global terms, the energy security and climate change nexus has clearly remained in energy policy. Thus the Key Government justifies the allocation of government resources to support the development of regulatory frameworks for investment in appropriate renewable projects. ${ }^{333}$ In regards to petroleum and mineral resources, it aims to ensure that 'regulatory settings maximise the return to $\mathrm{New}$ Zealanders while also promoting safety, preventing harm and requiring environmentally-responsible practices.' 334 These are both based on its assertion that using a wide range of resources will 'help make New Zealand more resilient to fluctuating commodity prices, leading to improved energy security.' 335 Both renewable resources, as well as petroleum and mineral resources, are given focus in the NZES 2011.

The Clark Government's institutional politicisation of energy security risks however, has not been retained. This has hindered coherent policy and energy system change based on a more urgent sense to address climate change. First, the Key Government retracted the energy security and climate change framework to the MED, as demonstrated in Chapter Four. Second, the Ministerial roles in

\footnotetext{
${ }^{333}$ Ministry of Economic Development, "New Zealand Energy Strategy 2011 - 2021: Developing Our Energy Potential." p. 4 and 5

${ }^{334}$ Ministry of Economic Development, "New Zealand Energy Strategy 2011 - 2021: Developing Our Energy Potential." p. 4 and 5

335 Ibid. p. 4
} 
Energy and Climate Change were separated. Energy security no longer appears in the mandates of other government departments as it did under David Parker's watch. The Clark Government's whole-of-government approach has been stalled. Thus coherent policy development on climate change and energy, which are inexorably linked, is hindered. This is problematic insofar as a government focus on mineral and petroleum resources can develop contradictions with climate change policy. For instance, New Zealand's climate change delegation must actively participate in negotiations with other developed and developing nations to resolve issues and encourage all to reduce emissions. Yet, domestic energy policy suggests that New Zealand is more than willing to develop its mineral and petroleum resources for export-earnings. Climate change negotiations aim to reduce the consumption of these very resources.

Politicisation has indeed, lead to a political flip-flop on energy security and climate change in New Zealand energy policy. This is problematic not only for a coherent whole-of-government energy policy, but also for the energy sector. It is political uncertainty over risk that presents particular challenges for the domestic market. In regards to the electricity market structure and regulation, the investment company Infratil with holdings in TrustPower, stated that '[i]t is easier to forecast (and respond to) economic, resource or technology changes than changes in political inclination.' 336 The market does respond to policy changes. The company states that it has transitioned from anticipating that electricity would be increasingly generated by large coal/gas plants, to now expecting future electricity needs will largely come from renewable sources.'337 There is uncertainty in the future of New Zealand's energy policy, and to whether policies will be enhanced to ensure a secure, sustainable and decarbonised future. IEA executive director Nobuo Tanaka noted this as a key challenge over the long-term. ${ }^{338}$ The IEA report on New Zealand, released in 2010

\footnotetext{
336 Infratil Limited, "Infratil Update," no. 33 (March 2011). p. 6

${ }^{337}$ Ibid. p. 1

338 Kiran Chug, "Nz Praised for Energy Policy but Warned About 'Challenges'," The Dominion Post 11 May 2011.
} 
stated that 'in recent years, the energy policy environment has been marked by uncertainty. It is difficult to fully assess the long-term potential and effectiveness of energy policy when significant changes occur on a regular basis.' ${ }^{339}$ This was in reference to the review and revision of the NZES 2007 in order to create the draft NZES 2010. The IEA's comments were based on the notion that it is governments, and how they respond to the twin challenges of climate change and energy security, 'that will shape the future of energy in the longer term.' 340 The NZES 2011 though finalised, has changed in semantics but not in content. It maintains a focus on developing renewable, petroleum and mineral resources.

Politicisation is not a hindrance to substantive energy policy development. Analysis of New Zealand's energy policy and debate suggests that energy security is more a case of rhetoric banter. First, some core issues have not changed between the Governments' energy policies. New Zealand is relatively self-sufficient when it comes to energy, except for its reliance on access to the international energy market. While the Clark Government presented this reliance as a potential source of risk to New Zealand's economy and energy security, the NZES 2011 released under the Key Government perceived it as a source of opportunity for export and development. But developing New Zealand's resources, including gas, oil, and coal, is nothing new to energy policy. Both governments have made movements in these areas. The Clark Government supported petroleum exploration in New Zealand in its 2005 Minerals Programme for Petroleum. ${ }^{341}$ Likewise, under the Key Government the process of review and implementation of the National Policy Statement on renewables is underway. The Executive Summary of the 'Proposed National Policy Statement for Renewable Electricity Generation,' released by the Ministry for the Environment, states the following,

\footnotetext{
339International Energy Agency, "Executive Summary and Key Recommendations." p. 9 340 _ - - , "World Energy Outlook 2010: Executive Summary." p. 3

341 Ministry of Economic Development, "Draft New Zealand Energy Strategy and the Draft New Zealand Energy Efficiency and Conservation Strategy." p. 16
} 
Assuming no change in New Zealand's approach to electricity generation transmission and consumption, electricity-related greenhouse gas (GHG) emissions are projected to rise by 50 per cent by 2030. The government believes this would not only be environmentally irresponsible, but that it would place New Zealand exports at a disadvantage, increase the country's exposure to the cost of imported fossil fuels and threaten New Zealand's reputation as a clean, green tourist destination. As such, the government has adopted a target for renewable electricity generation of 90 percent by 2025 (based on delivered electricity in an average hydrological year). ${ }^{342}$

While not couched in terms of energy security, clearly the question of electricity generation in New Zealand is viewed through both environmental and economic lenses. Second, there is a recognition that the energy system does need to change and that business-as-usual will not suffice. This points to the fact that the politics of energy security is more to do with window-dressing of energy policy rather than representative of a substantive policy shift. Dr Richard Hawke argues that the NZES 2007 and 2011 can be viewed as quite different, or not different at all, adding that 'the core issues have not changed much, just about which issue has primacy.'343

Politicisation is a strategy that aims to prioritise one issue above another in political debate. And, this is exactly what has occurred between the two Governments. The traditionally passive role energy security plays in public debate and policy means it's currently political fodder; something that follows the latest trends (climate change policy or a global economic recession), as seen in the two distinct rhetorical politicisations of energy security in the NZES 2007 and NZES 2011. Current strategy suggests that consideration of environmental and

\footnotetext{
${ }^{342}$ Ministry for the Environment, "Proposed National Policy Statement for Renewable Electricity Generation." p. 1

${ }^{343}$ Hawke, "Interview."
} 
social risks are the subject of political spin. Politicisation of energy security contributes to this spin. For instance, the contribution of New Zealand's development of petroleum and mineral resources to global energy security is like a drop in the ocean of an enormous, and growing, international demand for energy. Likewise, arguing that a reduction in our greenhouse gas emissions is like a drop taken from the ocean of another enormous problem on the global scale. ${ }^{344}$ Yet energy security issues are not left from scrutiny and debate, despite the spin.

In parliamentary Order Paper and Questions, on 23 September, the Hon Trevor Mallard inquired with the Minister of Energy and Resources, the Hon Gerry Brownlee, whether he had read the documents released by the UK Industry Taskforce on Peak Oil and Energy Security including 'The Oil Crunch: Securing the UK's Energy Future' and 'The Oil Crunch - a wake-up call for the UK economy?'345 These reports argue that the world will face an 'oil crunch' where 'oil prices are likely to be both higher and more volatile, and where oil price shocks have the potential to destabilise economic, political and social activity.'346 The reports highlight that addressing this crunch, and the urgency required to address the impacts of climate change, mean that government and businesses must 'Act now.' 347 In October 2010, a New Zealand Parliamentary Library Research Paper entitled 'The next oil shock?' stated that '[t]here is a risk that the world economy may be at the start of a cycle of supply crunches leading to price spikes and recessions, followed by recoveries leading to supply crunches.' ${ }^{348}$ Furthermore, domestic oil production cannot insulate New Zealand from these

\footnotetext{
344 See IPCC, "Climate Change 2007: The Physical Science Basis," in IPCC Fourth Assessment Report (AR4) (IPCC, 2007).; Hansen et al., "Dangerous Human-Made Interference with Climate: A Giss Modele Study," Atmospheris Chemistry and Physics 7(2007).

${ }^{345}$ Hon Trevor Mallard, 22 September 2010.; - - - , 22 September 2010.

346 Industry Taskforce on Peak Oil \& Energy Security, "The Oil Crunch: A Wake-up Call for the Uk Economy," in Second report of the UK Industry Taskforce on Peak Oil \& Energy Security (ITPOES), ed. Simon Roberts (LondonFebruary 2010). p. 4

347 Ibid. p. 5

348 Parliamentary Library, "The Next Oil Shock?," (Wellington, October 2010). p. 1
} 
shocks, and that key-export-generating industries such as tourism, dairy and meat exports are very vulnerable to these shocks.

The thesis shows that the energy debate in New Zealand is evolving and slowly becoming more robust. The politicisation of energy security has not hindered this debate, shown in the continued points of contention that exists between politicians, bureaucrat, key stake-holders in energy policy, energy market participants and academics. For instance, Professor Barry Barton states that signals of pending scarcity in the Maui gas and electricity issues in New Zealand, 'have not translated well into investment and development.' ${ }^{349}$ He argues that because of this, policy-makers and business must take this message to heart. The 'Business as usual - characterised by ever growing energy consumption that is met from environmentally and socially damaging energy-supply-side projects simply cannot continue, in the long-term, we cannot drill, dam and dynamite our way to energy security.'350 In recent national news, Professor Ralph Sims argues that currently New Zealand is not fulfilling its potential for renewable energy use, with little to encourage growth in that area. While renewable energy use was growing globally, in New Zealand 'cost, awareness and policy leadership were all barriers.' 351 In opposition to this, the acting Minister for Energy and Resources Hon Hekia Parata stated that the Government 'is focused on renewables, the exploration of natural resources, energy efficiency and the pricing of carbon while managing environmental responsibilities and economic opportunities,' finally, that the Government retains the aspiration of 90 percent of electricity generation to be from renewables sources by 2025. 352 Notably in these more public debates energy security is not often referenced directly.

\footnotetext{
${ }^{349}$ Barton et al., Energy Security: Managing Risk in a Dynamic Legal Environment; Barry Barton et al., Energy Security: Managing Risk in a Dynamic Legal Environment. p. 456

${ }^{350}$ Barton et al., Energy Security: Managing Risk in a Dynamic Legal Environment; Barry Barton et al., Energy Security: Managing Risk in a Dynamic Legal Environment. p. 456

${ }^{351}$ Chug, "NZ Praised for Energy Policy but Warned About 'Challenges'." p. 1

352 Ibid. p. 1
} 
The low public awareness of energy issues in New Zealand however, is a problem that needs to be addressed. Rhetorical politicisation of energy security has neither helped nor hindered this. First, Professor Ralph Sims identified low public awareness of energy issues as a key problem in New Zealand. He added that there will be 'no change in policy unless [there is] a change in public attitude.' 353 If the Clark Government wanted to raise the salience of climate change and energy security issues in the public's minds, clearly the current energy strategy suggests that this has not been successful. Energy security in particular, plays a passive role in the public debate on energy issues. It is more behind the policy-making doors, amongst key-stakeholders, bureaucrats and politicians, where the energy security and climate change nexus is contested (in these specific terms.) Yet more public challenges to energy policy are emerging from the business sector. The recent Pure Advantage Campaign spear-headed by top New Zealand business leaders Sir Stephen Tindall, Philip Mills, and Rob Morrison, is an example of this. They argue that environmental degradation and policy in New Zealand is 'eroding our 100\% Pure image, and putting our crucial tourism and export industries at risk.' 354 They call for thorough investigation on what motivates New Zealand to go green growth, and where the risks lie in running business as usual. ${ }^{355}$ Furthermore, their campaign challenges a 'perceived lack of leadership on linking clean technology with protecting and making true New Zealand's “clean, green" brand.'356 Note here that this public debate does not include references to energy security. Politicisation therefore, would appear negligible in hindering the development of this discourse. If anything, as Chapter Five suggests, it would stimulate it. As noted previously, in Securitisation Theory politicisation is when an issue is addressed within politics meaning it is always open to debate.

\footnotetext{
353 Sims, "Interview."

${ }^{354}$ Pure Advantage, "Threats on the Horizon," pureadvantage.org, http://www.pureadvantage.org/why-green-growth/threats-on-the-horizon/. 355 - - - , "Why Green Growth," pureadvantage.org, http://www.pureadvantage.org/whygreen-growth/. 356 Pattrick Smellie, "Clean Tech Initiative Shoots for Stars as Government Stays Down to Earth," The Dominion Post 7 July 2011.
} 
The debate on energy security will simply not go away. And it is best New Zealand continues to have a critical debate that continues to question what energy security means, and how best it is achieved. The policy measures seem to be in place for this debate to take place with due consideration of climate change policy. Although, current rhetoric in the NZES 2011 shows that robust consideration has waned. The recent announcement that the Government is considering slowing down implementation of the Emissions Trading Scheme reflects this mood. 357 The rhetorical politicisation of energy security seems to reflect this mood as well. Energy security rhetoric however, can easily morph into different forms depending on economic, social, and political conditions or indeed, sudden events and shocks. These conditions are not static in New Zealand, and change will occur. As the Introduction to this thesis highlighted, the energy security and climate change nexus has not been omitted from international debate. Energy security will not be assured without climate security. 358 Energy security should be questioned in New Zealand because climate change will continue to create challenges for energy policy. The Introduction also highlighted that the world's energy future is uncertain, according to the IEA. The uncertainty the global energy sector faces is not only because of rising oil prices and rising global demand for energy, but also because of uncertainty in countries' energy policy. There is an increasing urgency to give some clear and consistent signals (particularly for the energy market) in the present that will foreshadow the long-term policy response for the future. ${ }^{359}$

New Zealand's two distinct rhetorical politicisations of energy security have mimicked this uncertainty in domestic energy policy. This is not a problem solved by stating who is right; Labour, National or the energy sector. By no means is it a problem easily solved at all. However, in arguing that energy security risks are contested in New Zealand I have sought to show that energy

\footnotetext{
${ }^{357}$ NZ Herald, "Nzers Fear Cost of Climate Change - Survey," nzherald.co.nz, http:/ / www.nzherald.co.nz/nz/news / article.cfm?c_id=1\&objectid=10743959.;

359 International Energy Agency, "World Energy Outlook 2010: Executive Summary." p. 3

359 International Energy Agency, "World Energy Outlook 2010: Executive Summary." p. 3
} 
security should not be taken for granted. Neither when referenced by politicians and market actors, nor in the mandates of government departments. Recognising that energy security should be questioned (as by policy-makers and scholars internationally) is particularly important to New Zealand, as the country has enjoyed a free-ride and an abundance of renewable resources. New Zealand is in this position because of its good resources, not because of policy. ${ }^{360}$ Second, as Barry Barton notes energy security problems exist whatever the policy mix. ${ }^{361}$ It appears that politicisation of energy security has helped this debate, even though energy policy has flip-flopped from robust climate change policy to a focus on the development of petroleum and mineral resources. Despite the fact that energy security is to some extent portrayed as a straight-forward concept, the evolving energy debate will hopefully continue to suggest otherwise.

${ }^{360}$ Chug, "NZ Praised for Energy Policy but Warned About 'Challenges'."

${ }^{361}$ Barton et al., Energy Security: Managing Risk in a Dynamic Legal Environment. P. 389 


\section{Bibliography}

AFP. "Food, Energy Security on Table at Big Europe-Asia Meet." google.com/hostednews/afp,

\begin{tabular}{|c|c|}
\hline$\frac{\text { http://www.google.com/hostednews/afp/article/ALeqM5io2sBzTHw2NHiszRKEkFq7SyD }}{\text { 3ew?docld=CNG.4c6d9a705302133fcb33283701223ce3.481 }}$ \\
- - . "New Zealand's PM-Elect Unveils Cabinet with Focus on Economy."
\end{tabular}

www.channelnewsasia.com,

http://www.channelnewsasia.com/stories/afp asiapacific/view/390354/1/.html

Andrews-Speed, Philip. "Energy Security in East Asia: A European View." In Symposium on Pacific Energy Cooperation 2003. Tokyo, 2003.

Aotearoa Wave and Tidal Energy Association (AWATEA). "Submission on the New Zealand Energy Strategy, New Zealand Energy Efficiency and Conservation Strategy, Energy Research Roadmap and Related Climate Change Documents." edited by AWATEA. Wellington.

APEC. "Apec Energy Ministers Focus on Low-Carbon Energy Security."

\begin{tabular}{|l|}
\hline \multicolumn{2}{|c|}{ http://climate-l.iisd.org/news/apec-energy-ministers-focus-on-low-carbon-energy- } \\
\hline security/f.
\end{tabular}

APERC. "Apec Energy Overview 2009." The Institute of Energy Economics, Japan, 2010.

Armstrong, Bill. "Todd Energy Submission on National Policy Statement on Renewable Electricity Generation " mfe.govt.co.nz, http://www.mfe.govt.nz/rma/central/nps/generation/submissions/77-todd-enegry.pdf, ASEAN. "Cebu Declaration on East Asian Energy Security." aseansec.org, http://www.aseansec.org/19319.htm.

Australian Government. "National Energy Security Assessment 2009." Canberra, Australia, 2009.

Bahgat, Gawdat. "Europe's Energy Security: Challenges and Opportunities." International Affairs 82, no. 5 (2006).

Barry Barton et al. Energy Security: Managing Risk in a Dynamic Legal Environment. New York: Oxford University Press, 2004. 
Barton, Barry. "Interview." (2011).

Barton, Barry, Catherine Redgwell, Anite Ronne, and Donal N Zillman. Energy Security: Managing Risk in a Dynamic Legal Environment. New York: Oxford University Press, 2004.

Becken, Susanne. "Submission to the New Zealand Energy Strategy." edited by Lincoln University. Christchurch, 31 August 2010.

Bertram, Geoff, and Simon Terry. The Carbon Challenge: New Zealand's Emissions Trading Scheme. Wellington: Bridget Williams Books, 2010.

Brown, Oli, Anne Hammill, and Robert McLeman. "Climate Change as the 'New' Security Threat: Implications for Africa." International Affairs 83, no. 6 (November 2007): 1141-54.

Brownlee, Hon Gerry. "Government Consulting on Energy Policy." \begin{tabular}{|l|lll}
\hline www.med.govt.nz & http://www.med.govt.nz/templates/Page 44122.aspx \\
\hline
\end{tabular}

- - - "Opening Address to the New Zealand Petroleum Conference." Paper presented at the Petroleum Conference, 20 September 2010.

- - . "Security Underlines National's Energy Policy." national.org.nz, http://www.national.org.nz/Article.aspx?ArticlelD=28380.

Bush, George W. "State of the Union Address." The National Business Review, http://m.nbr.co.nz/article/state-union-address.

Buzan, Barry, and Ole Waever. "Macrosecuritisation and Security Constellations: Reconsidering Scale in Securitisation Theory." Review of International Studies 35 (2009): 253 - 76.

Buzan, Barry, Ole Waever, and Jaap de Wilde. "The Economic Sector." In Security: A New Framework for Analysis. London: Lynne Rienner Publishers, 1998. - - - Security: A New Framework for Analysis: Lynne Rienner Publishers, 1998.

Cairns, Lois. "Greenpeace: Oil Exploration's Political Hot Potato." nzherald.co.nz,

\begin{tabular}{|l|}
\hline \multicolumn{2}{|c|}{ http://www.stuff.co.nz/national/politics/5297054/Greenpeace-Oil-explorations- } \\
\hline political-hot-potato
\end{tabular}

Calman, Stuart. "Interview." 2011. 
Chauvel, Charles. "Brownlee Reforms Will End up Costing Taxpayers." labour.org.nz, http://www.labour.org.nz/news/brownlee-reforms-will-end-costingtaxpayers

- - . "Energy and Resources Policy in New Zealand: Where's the Plan?" labour.org.nz, http://www.labour.org.nz/news/energy-and-resources-policy-newzealand-where\%E2\%80\%99s-plan.

- - . "ETS Uncertainty Points to Serious Energy Problems." labour.org.nz, http://www.labour.org.nz/news/ets-uncertainty-points-serious-energy-problems, - - - "No-Show Brownlee's Got No Plan." labour.org.nz, http://www.labour.org.nz/news/no-show-brownlee\%E2\%80\%99s-got-no-plan.

Chug, Kiran. "NZ Praised for Energy Policy but Warned About 'Challenges'." The Dominion Post, 11 May 2011.

Ciuta, Felix. "Security and the Problem of Context: A Hermeneutical Critique of Securitisation Theory." Review of International Studies, no. 35 (2009): 301 - 26. Colin Innes \& Simon Rushton. "Hiv, Aids and Security: Where Are We Now?" International Affairs 86, no. 1 (January 2010): 225-45.

Deutch, John. "Prority Energy Security Issues." In Energy Security and Climate Change: A Report to the Trilateral Commission, edited by John Deutch; Anne Lauvergeon; Widhyawan Prawiraatmadja. Washington, Paris, Tokyo: The Trilateral Commission, 2007.

Dupont, Alan. "Climate Change and Security: Managing the Risk." Garnaut Climate Change Review (June 2008),

\begin{tabular}{|l|l|}
\hline \multicolumn{2}{l}{ http://www.garnautreview.org.au/CA25734E0016A131/WebObj/05Security/\$SFile/05\%2 } \\
\cline { 1 - 1 } OSecurity.pdf.
\end{tabular}

Environment and Community Development Committee. "Consultation Reponse to Draft New Zealand Energy Strategy and New Zealand Energy Efficiency and Conservation Strategy." edited by Jake Roos. Kapiti Coast District, 2 September 2010.

Europe, Economic Commission for. "Emerging Energy Security Risks and Risk Mitigation in a Global Context." In ECE Energy Series, edited by United Nations. New York and Geneva, 2007. 
- - -. "Investing in Energy Security Mitigation." In Energy Series, edited by United Nations. New York and Geneva, 2008.

Fitzsimons, Jeanette. "Electricity (Renewable Preference) Repeal Bill - First Reading, Second Reading, in Committee, Third Reading." parliament.nz,

\begin{tabular}{|l|}
\hline http://www.parliament.nz/en- \\
\hline NZ/PB/Debates/Debates/Speeches/0/7/d/49HansS 20081217 00001201-Fitzsimons- \\
\hline Jeanette-Electricity-Renewable.htm. \\
\hline
\end{tabular}

Floyd, Rita. "The Environmental Security Debate and Its Significance for Climate Change " The International Spectator, 43, no. 3 (2008): 51 - 65.

Froggatt, Antony, and Michael A Levi. "Climate and Energy Security Policies and Measures: Synergies and Conflicts." International Affairs 85, no. 6 (2009): 1129 - 41.

Gas and LPG Associations of New Zealand. "Submission on the Draft Nz Energy Strategy and the Draft Nzeecs: Comments from the Gas and Lpg Associations." edited by Jim Coe. Wellington, 30 March 2007.

Genesis Energy. "Target 2030 Planning the Future of New Zealand Energy: Integrated Submission on Four Consultation Papers." edited by Murray Jackson, 30 March 2007.

Giddens, Anthony. "The Politics of Climate Change: National Responses to the Challenges of Global Warming." www.policy-network.net (September 2008).

Goldenberg, Suzanne. "Republicans Attack Obama's Environmental Protection from All Sides." guardian.co.uk,

\begin{tabular}{|l|}
\hline http://www.guardian.co.uk/world/2011/mar/04/republicans-attack-obamas- \\
\hline environmental-protection?INTCMP=SRCH. \\
\hline
\end{tabular}

Green Party. "Joint Submission on the Energy Strategy (Nzes) and the Energy Efficiency and Conservation Strategy (Nzeecs)." edited by Metiria Turei and Dr. Kennedy Graham. Wellington, 2 September 2010.

Hansen et al. "Dangerous Human-Made Interference with Climate: A Giss Modele Study." Atmospheris Chemistry and Physics 7 (2007).

Harks, Enno. "The Conundrum of Energy Security - Gas in Eastern and Western Europe." The International Spectator 3 (2006). 
Harris, Stuart, and Barry Naughten. "Economic Dimensions of Energy Security in the Asia-Pacific." In Energy Security in Asia, edited by Michael Wesley. New York: Routledge, 2007.

Hawke, Richard. "Interview." (2011).

Helm, Dieter. "Energy Policy: Security of Supply, Sustainability and Competition." Energy Policy 30, no. 3 (February 2002): 173-84.

Holland, Andrew. "Climate Change and Energy Security: Overlapping Priorities." In IISS Transatlantic Dialogue on Climate Change and Security. Hyatt Regency Capitol Hill, Washington, D.C.: International institute for Strategic Studies, 16 March 2010.

Hon Dr Nick Smith. "Nick Smith: Climate Change and Business Conference." scoop.co.nz, http://www.scoop.co.nz/stories/PA0908/S00351.htm.

Hon Gerry Brownlee. "Security Underlines National's Energy Policy." national.org.nz, http://www.national.org.nz/Article.aspx?ArticlelD=28380

IEA. World Energy Outlook 2007: China and India Insights. Paris: International Energy Agency, 2007.

Industry Taskforce on Peak Oil \& Energy Security. "The Oil Crunch: A Wake-up Call for the Uk Economy." In Second report of the UK Industry Taskforce on Peak Oil E Energy Security (ITPOES), edited by Simon Roberts. London, February 2010.

Infratil Limited. "Infratil Update." no. 33 (March 2011).

Interactive/AAP. "Kiwis Feel Price Pinch, More to Come." tvnz.co.nz, http://tvnz.co.nz/content/425389/425823.htm

International Enegry Agency. "New Zealand 2006 Review." In Energy Policies of IEA Countries. Paris: IEA/OECD, 2006.

International Energy Agency. "Executive Summary and Key Recommendations." http://www.iea.org/Textbase/npsum/NewZealand2010SUM.pdf.

- - -. "World Energy Outlook 2010: Executive Summary." edited by OECD/IEA. Paris: International Energy Agency, 2010.

IPCC. "Climate Change 2007: The Physical Science Basis." In IPCC Fourth Assessment Report (AR4): IPCC, 2007. 
Joubert, Leonie. "Africa: Climate Change 'Is a Security Issue'." Global Information Network (31 August 2009).

Key, John. "Budget 2010 About Opportunity for Kiwis." edited by Releases: beehive.govt.nz, 20 May 2010.

Ki-moon, Ban. "Remarks to Climate Change Conference (Unfccc Cop16 HighLevel Segment) - $\quad$ as Delievered." un.org, http://www.un.org/apps/news/infocus/sgspeeches/statments full.asp?statID=1028.

LaCasse, Chantale, and Andre Plourde. "On the Renewal of Concern for the Security of Oil Supply." Energy Journal 16, no. 2 (April 1995): pp. 1 - 23.

Laiming, Luo. "More Global Cooperation Needed to Ensure Energy Security: G20 Business Summit." Xinhua, http://english.cri.cn/6826/2010/11/11/2742s604462.htm

Local Government New Zealand. "Submission to the Ministry of Economic Development on the Draft Nz Energy Strategy, and the Draft Nz Energy Efficiency and Conservation Strategy 2010." Wellington, 2 September 2010. Lynch, Brian, ed. Energy Security: The Foreign Policy Implications. Wellington: New Zealand Institute of International Affairs, 2008.

Mabee, Bryan. "Re-Imagining the Borders of Us Security after 9/11: Securitisation, Risk, and the Creation of the Department of Homeland Security." Globalizations 4, no. 3 (2007): 385 - 97.

MacNaughton, Joan. "Cooperating on Energy Policy: The Work of the International Energy Agency." In The New Economic Diplomacy: DecisionMaking and Negotiation in International Economic Relations, edited by Nicolas Bayne; Stephen Woolcock, pp. 279 - 95. Burlington, USA: Ashgate, 2007.

Makarychev, Andrey. "Energy Relations in Russia: Administration, Politics and Security." International Social Science Journal 57, no. Supplement s1 (May 2005): 107 - 17.

Mallard, Hon Trevor. 23 September 2010.

- - - 22 September 2010.

- - - 22 September 2010. 
McDonald, Matt. "Securitisation and the Construction of Security." European Journal of International Relations 14, no. 563 (2008).

Mely Caballero-Anthony, Collin Koh. "The Way Forward for Energy Security." Centre for Non-Traditional Security (NTS) Studies: Policy Brief (December 2008).

Ministry for the Environment. "Archived Publication: Renewable Energy Solutions Combat Climate Change." mfe.govt.nz, http://www.mfe.govt.nz/publications/about/environz/environz-jul07/page8.html

- - - . "Archived Publication: Why a New Zealand Emissions Trading Scheme?".

Wellington: Ministry for the Environment, September 2007.

- - - . "Discussion Paper on Measures to Reduce Greenhouse Gas Emissions in New Zealand Post-2012." mfe.govt.nz,

\begin{tabular}{|l|}
\hline http://www.mfe.govt.nz/publications/climate/discussion-paper-post-2012- \\
\hline dec06/html/page3.html.
\end{tabular}

- - . "Proposed National Policy Statement for Renewable Electricity

Generation." mfe.govt.nz, http://www.mfe.govt.nz/publications/rma/nps-forrenewable-electricity-generation-ris/html/page1.html.

- - - "Statement of Intent 2007 - 2010." Wellington: Ministry for the Environment,, May 2007.

- - - "Statement of Intent 2009 - 2012." Wellington: Ministry for the Environment, May 2009.

- - - "Statement of Intent 2010 - 2013,." Wellington: Ministry for the Environment,, May 2010.

- - - "Value of the Environment to the Economy." mfe.govt.nz,

\begin{tabular}{|l|}
\hline \multicolumn{2}{l}{ http://www.mfe.govt.nz/publications/ser/enz07-dec07/html/chapter2- } \\
\hline environment/page5.html. \\
\hline
\end{tabular}

Ministry of Defence. "Defence White Paper ". Wellington: Ministry of Defence,, 2010.

Ministry of Economic Development. "Developing a New Zealand Energy Strategy - Terms of Reference." Wellington, 2004. 
- - - . "Draft New Zealand Energy Strategy and the Draft New Zealand Energy Efficiency and Conservation Strategy." Ministry of Economic Development, July 2010.

- - - "New Zealand Energy Strategy 2011 - 2021: Developing Our Energy

Potential." Ministry of Economic Development, August 2011.

- - - "New Zealand Energy Strategy 2011 - 2021: Developing Our Energy

Potential." Ministry of Economic Development, 2011.

- - - . "New Zealand Energy Strategy to 2050: Powering Our Future." Ministry of Economic Development, October 2007.

- - - "New Zealand Energy Strategy: Developing Our Energy Potential and the New Zealand Energy Efficiency and Conservation Strategy."

Wellington: Ministry of Economic Development,, 2011.

- - . "Questions and Answers."

www.med.govt.nz,

http://www.med.govt.nz/templates/Page 44120.aspx

- - - . "Sustainable Energy - Summary." In New Zealand Government's Sustainable

Development Programme of Action. Wellington, 2004.

- - " "Working with Sectors." med.govt.nz, http://www.med.govt.nz/templates/StandardSummary 44546.aspx

Ministry of Foreign Affairs and Trade. "3 Other Key Relationships: The United

States (Us)." mfat.govt.nz, November 2008.

- - - "37th Meeting of the Pacific Islands Forum." Paper presented at the

Forum Communique, Nadi, Fiji, 24-25 October 2006.

- - - . "Annual Report 2007/08." mfat.govt.nz, For the year ended 30 June 2008.

- - . "Asia-Pacific Economic Cooperation (Apec)." mfat.govt.nz,

\begin{tabular}{|r|}
\hline \multicolumn{2}{|c|}{ http://www.mfat.govt.nz/Media-and-publications/Publications/Trade-matters/0- } \\
\hline apec.php \\
- - "New Zealand's International Climate Change Policy" mfat.govt.nz,
\end{tabular}

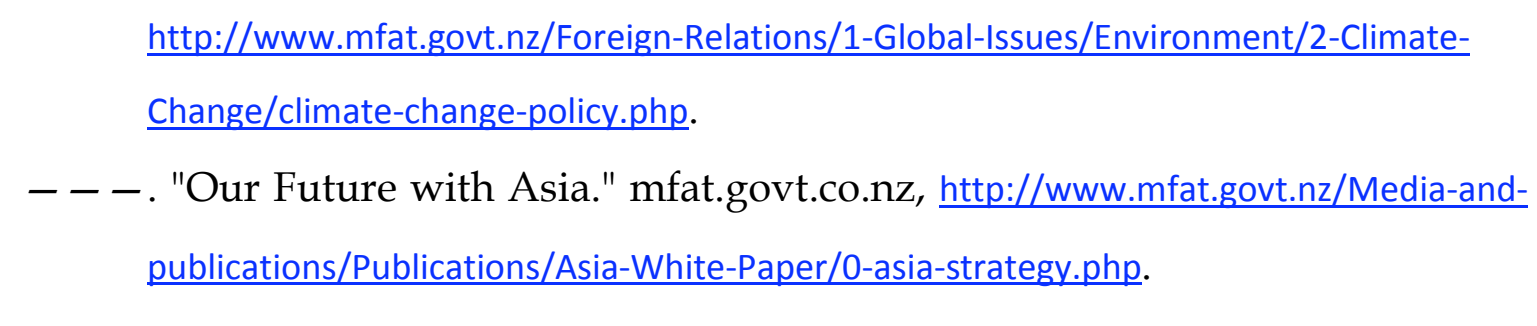


- - - " "Our Future with Asia." Wellington, 2007.

- - - "Statement of Intent 2007-2010 Incorporating the Forecast Financial Statements for 2007/08." Ministry of Foreign Affairs and Trade,, 2007.

_ - - . "Statement of Intent 2010 - 2013." New Zealand Government, 2010.

Ministry of Transport. "The New Zealand Transport Strategy." edited by Ministry of Transport: newzealand.govt.nz, 2008.

Mitchell, J. V. "Energy Supply Security: Changes in Concepts." In Seminaire Europeen sur la Securite d'approvisionnement Energetique

Paris Ministry of Economy, Finance and Industry, 2000.

Mitchell, John V. "Renewing Energy Security." The Royal Institute of International Affairs: Sustainable Development Programme (July 2002).

Nasheed, Mohamed. "Climate Change Requires a Real Movement." http://www.huffingtonpost.com/mohamed-nasheed/climate-change-requiresa b 292747.html

Natusch, David F.S. "New Zealand's Energy Reserves as Strategic Assets." In Energy Security: The Foreign Policy Implications, edited by Brian Lynch. Wellington: The New Zealand Institute of International Affairs, 2008.

New Zealand Transport Agency. "About Us." nzta.govt.nz, http://www.nzta.govt.nz/about/index.htm

- - -. "NZ Transport Agency's Approach to Research 2009-12." Wellington, October 2008.

Newman, Muriel. "Comment: Climate Change Review Echoes World Trend." The National Business Review, http://www.nbr.co.nz/article/comment-climate-changereview-echoes-world-trend-37859.

NZ Herald. "Nzers Fear Cost of Climate Change - Survey." nzherald.co.nz, http://www.nzherald.co.nz/nz/news/article.cfm?c id=1\&objectid=10743959.

Obama, Barack. "Obama Orders Push to Cleaner, More Efficient Cars." 3news.co.nz, http://www.3news.co.nz/Obama-orders-push-to-cleaner-more-efficientcars/tabid/728/articleID/88601/Default.aspx 
- - - "Remarks by the President on America's Energy Security." The White House, http://www.whitehouse.gov/the-press-office/2011/03/30/remarks-presidentamericas-energy-security,

Office of the Minister for Climate Change Issues, and Office of the Associate Minister for Climate Change Issues (International Negotiations). "Climate Change International Negotiations: Update and New Zealand Position." edited by Ministry of Foreign Affairs and Trade. Wellington: mfat.govt.nz, 2009.

Orion. "Security of Supply Standard." oriongroup.co.nz,

\begin{tabular}{|l|}
\hline \multicolumn{2}{|c|}{ http://www.oriongroup.co.nz/publications-and-disclosures/consultation/security-of- } \\
\hline supply-standard.aspx \\
\hline
\end{tabular}

Parker, David. "David Parker Speech: The End of Cheap Oil." Scoop.co.nz,

$$
\begin{aligned}
& \text { http://www.scoop.co.nz/stories/PA0611/S00004.htm } \\
& \text { - - - "Interview." (2011). } \\
& \text { - - - . "Interview." } 2011 .
\end{aligned}
$$

Parker, Hon. David. "Speech to Electrical Engineers Association Conference 2007." beehive.govt.co.nz, http://www.eea.co.nz/Attachment?Action=View\&Attachment id=447.

Parliamentary Library. "The Next Oil Shock?". Wellington, October 2010.

Petersson, Bo, and Barbara Tornquist-Plewa. "Energy Security in Europe: Proceedings from the Conference "Energy Security in Europe"." Paper presented at the The CFE Conference papers, Lund, Sweden, 2008.

Petroleum Exploration and Production Association of New Zealand. "Pepanz Energy Strategy Submission 2007." edited by John Pfahlert. Wellington, 30 March 2007.

- - - "Submission: Petroleum Exploration and Production Association of New Zealand (Pepanz)." edited by John Pfhalert, 10 August 2010.

Pure Advantage. "Threats on the Horizon." pureadvantage.org,

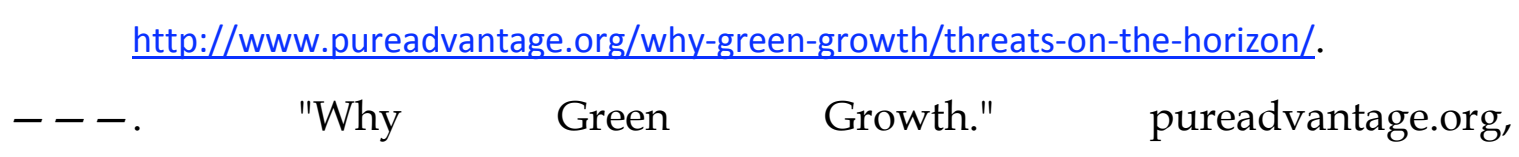
http://www.pureadvantage.org/why-green-growth/ 
Read, Ellen, and Reuters. "Oil Price Increases About to Hit Home." nzherald.co.nz,

\begin{tabular}{|c|c|c|c|c|}
\hline \multirow{3}{*}{ RNZ. } & \multicolumn{4}{|c|}{ http://www.nzherald.co.nz/markets/news/article.cfm?c id=62\&objectid=3581165 } \\
\hline & Follow & Oil & Higher." & tvnz.co.nz, \\
\hline & http://tvnz.co.nz/view/page/411319/593350 & & & \\
\hline
\end{tabular}

RSIS Centre for Non-Traditional Security Studies. "Executive Summary." In RSISNTS Workshop on Nuclear Energy and Human Security

Traders Hotel, Singapore: S. Rajarantnam School of International Studies, 23 April 2010.

Sauter, Raphael. "E.U. Energy Security from an Agenda-Setting Perspective Implications for E.U. Climate Change Policy?" Paper presented at the Energy Security in Europe: Proceedings from the Conference "Energy Security in Europe"

Lund, Sweden, 2008.

Shanahan, Dennis. "Kiwi Pm Wants Trans-Tasman Consensus on Emissions Trading." The Australian National Affairs,

\begin{tabular}{|l|}
\hline \multicolumn{2}{|c|}{ http://www.theaustralian.com.au/national-affairs/climate/kiwi-pm-wants-ets- } \\
\hline consensus/story-e6frg6xf-1111119013985 \\
\hline Shell International BV. "Shell Energy Scenarios to 2050. An Fra of Volatile
\end{tabular}

Shell International BV. "Shell Energy Scenarios to 2050: An Era of Volatile Transitions." In Shell Scenarios to 2050: Signals and Signposts. The Hague: Shell Internation BV, 2011.

Sims, Ralph. "Interview." (2011).

Sjöstedt, Roxanna. "Exploring the Construction of Threats: The Securitization of Hiv/ Aids in Russia." Security Dialogue 39, no. 1 (March 2008): 7 - 29.

Smellie, Pattrick. "Clean Tech Initiative Shoots for Stars as Government Stays Down to Earth." The Dominion Post 7 July 2011.

Smith, Hon Nick. "Nick Smith: Climate Change and Business Conference." scoop.co.nz, http://www.scoop.co.nz/stories/PA0908/S00351.htm.

Smith, Hon Nick, and Hon Tim Groser. "Ministers' Position Paper: Gazetting New Zealand's 2050 Emissions Target." Ministry for the Environment, http://www.mfe.govt.nz/publications/climate/nz-2050-emissions-target/gazetting-nz2050-emissions-target.pdf 
Smith, Jared. "Trundle Welcomes Energy Strategy from Government." taranakidailynews.co.nz, http://www.stuff.co.nz/taranaki-dailynews/business/5563940/Trundle-welcomes-energy-strategy-from-government

Solid Energy. "Submission on Draft New Zealand Energy and Climate Change Strategies." edited by Solid Energy, March 2007.

Solid Energy New Zealand Limited. "Our Natural Resources." coalnz.com, http://www.coalnz.com/index.cfm/1,134,0,0,html/About-Solid-Energy.

Stritzel, Holger. "Towards a Theory of Securitisation: Copenhagen and Beyond." European Journal of International Relations 13, no. 357 (2007).

The Main Report Group. "Electricity Supply Security: Grid to Upgrade to Help Power Supply Security." themainreport.co.nz,

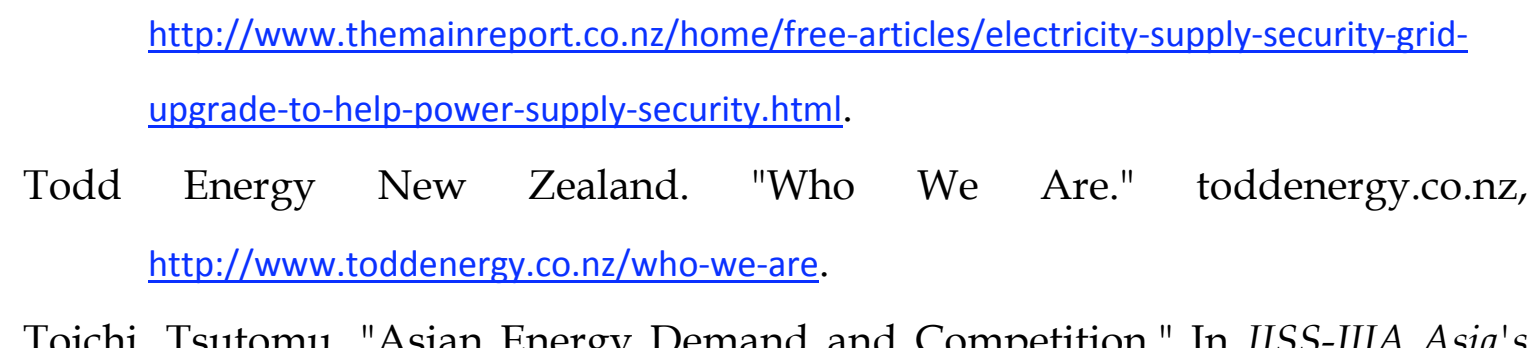

Toichi, Tsutomu. "Asian Energy Demand and Competition." In IISS-JIIA Asia's Strategic Challenges: In Search of a Common Agenda. Hotel Okura, Tokyo: The International Institute for Strategic Studies, 2-4 June 2008.

- - - "First Session - Asian Energy Insecurity." In IISS-JIIA Conference "Asia Energy Demand and Competition". Hotel Okura, Tokyo, Japan, 2 - 4 June 2008.

Transpower. "Security of Supply Important for South Island." scoop.co.nz, http://www.scoop.co.nz/stories/BU0702/S00244.htm

TrustPower. "Combined Submission Draft New Zealand Energy Strategy to 2050, Measures to Reduce Greenhouse Gas Emissions Post 2012, Transitional Measures, Draft National Energy Efficiency and Conservationa Strategy." 30 March 2007.

Tyndall, Jo. "Global Collaboration Towards Sustainability and Climate Change." In PIM Conference. University of Otago: business.otago.ac.nz, 11 November 2010. 
UPI. "Does Beijing Hold Key to Energy Security?" UPI.com (9 November 2010), http://www.upi.com/Science News/Resource-Wars/2010/11/09/Does-Beijing-hold-keyto-energy-security/UPI-76901289313937/.

Victor, David G, and Linda Yueh. "The New Energy Order." Foreign Affairs,no. 1 (January/February 2010), http://www.foreignaffairs.com/articles/65897/david-gvictor-and-linda-yueh/the-new-energy-order,

Vivoda, Vlado. "Evaluating Energy Security in the Asia-Pacific Region: A Novel Methodological Approach." Energy Policy 38 (2010): 5258 - 63.

Wellington City Council. "Submission to the Draft New Zealand Energy Strategy." edited by Strategy and Policy Committee. Wellington, 2 September 2010.

Wesley, Michael. Energy Security in Asia. New York: Routledge, 2007.

Wiener, Jenni. "Search for Oil Alternatives, Based on National Security, Goal of Clean Energy." VOANews.com,

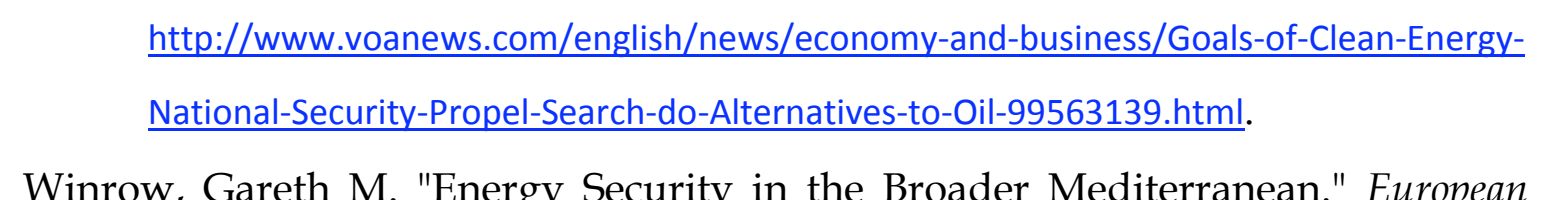
Security 17, no. 1 (March 2008): 161 - 83.

World Economic Forum and Cambridge Energy Research Associates. "The New Energy Security Paradigm." In World Economic Forum: Energy Vision Update. Geneva: World Economic Forum, Spring 2006.

Wu, Kang, Fereidun Fesharaki, Tomoko Hosoe, and David Isaak. "Strategic Framework for Energy Security in Apec." edited by National Center for APEC. Honolulu Hawaii: East West Center, 2008.

Wu Lei, Liu Xuejun. "China or the United States: Which Threatens Energy Security?" OPEC review 31, no. 3 (September 2007): 215 - 34.

Yergin, Daniel. "Ensuring Energy Security." Foreign Affairs 85, no. 2 (2006): 69-82.

Yi-Chong, Xu. "China's Energy Security." In Energy Security in Asia, edited by Michael Wesley. New York: Routledge, 2007.

Youngho, Chang. "Powering Growth: The Non-Traditional Security (N.T.S) Perspective on the Energy Security Policies in Singapore." In Asia Security 
Initiative Policy Series: Working Papers, edited by RSIS Centre for NonTraditional Security Studies. Singapore: S. Rajaratnam School of International Studies, June 2010.

Yueh, Linda. "An International Approach to Energy Security." Global Policy 1, no. 2 (May 2010).

ZB, Newstalk. "Greenpeace Not Backing Down." newstalkzb.co.nz, http://www.newstalkzb.co.nz/newsdetail1.asp?storylD=194414 